INTERNATIONAL MONETARY FUND

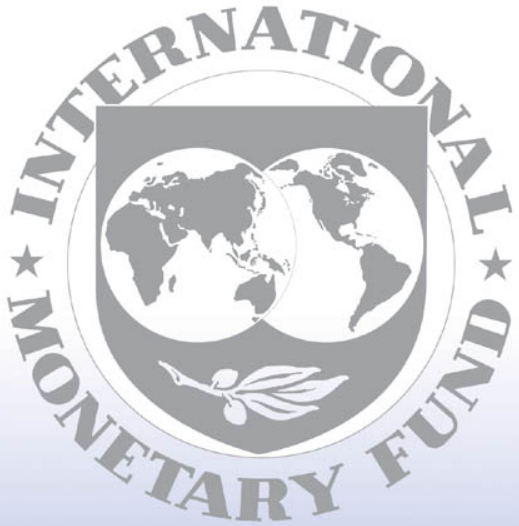

Staff

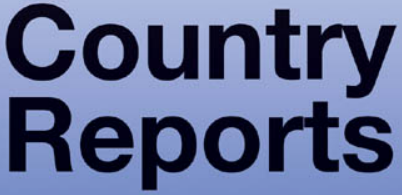




\section{Spain: Financial Sector Assessment Program-Detailed Assessment of the IMF Code of Good Practices on Transparency in Monetary and Financial Policies-Financial Policies}

This Detailed Assessment of the IMF Code of Good Practices on Transparency in Monetary and Financial Policies-Financial Policies for Spain was prepared by a staff team of the International Monetary Fund as background documentation for the Financial Sector Assessment Program with the member country. It is based on the information available at the time it was completed in May 2006. The views expressed in this document are those of the staff team and do not necessarily reflect the views of the government of Spain or the Executive Board of the IMF.

The policy of publication of staff reports and other documents by the IMF allows for the deletion of market-sensitive information.

To assist the IMF in evaluating the publication policy, reader comments are invited and may be sent by e-mail to publicationpolicy@imf.org.

Copies of this report are available to the public from

International Monetary Fund $\bullet$ Publication Services

700 19th Street, N.W. • Washington, D.C. 20431

Telephone: (202) 6237430 • Telefax: (202) 6237201

E-mail: publications@imf.org •Internet: http://www.imf.org

Price: $\$ 15.00$ a copy

International Monetary Fund

Washington, D.C. 
This page intentionally left blank

(C)International Monetary Fund. Not for Redistribution 
FinANCIAL SECTOR ASSESSMENT PROGRAM

\title{
SPAIN
}

DetaILed Assessment OF ObServance OF THE IMF CODE OF GOOD PRACTICES ON TRANSPARENCY IN MONETARY AND Financial Policies-Financial Policies

MAY 2006

\author{
INTERNATIONAL MONETARY FUND \\ Monetary and Financial Systems Department
}


Contents

Glossary $\underline{3}$

I. Banking Supervision. $\frac{\frac{4}{4}}{\frac{4}{5}}$

A. Information and Methodology Used for Assessment ............................................

B. Institutional and Market Structure.......................................................................

C. Practice-by-Practice Assessment..........................................................................

D. Recommended Action Plan and Authorities' Response to the Assessment ............22

II. Securities Markets Supervision .$\underline{24}$

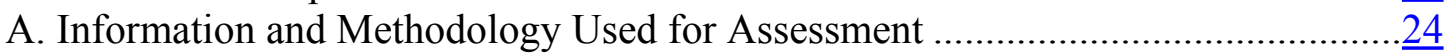

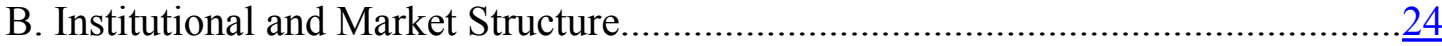

C. Practice-by-Practice Assessment................................................................

D. Recommended Action Plan and Authorities' Response to the Assessment ............ 40

III. Deposit Insurance .$\underline{42}$

A. Information and Methodology Used for Assessment ……..............................

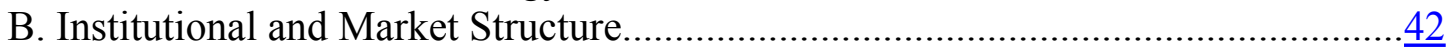

C. Practice-by-Practice Assessment.......................................................................43

D. Recommended Action Plan and Authorities' Response to the Assessment ............

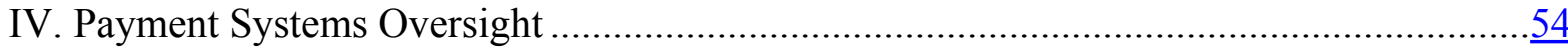

A. Information and Methodology Used for Assessment ………..........................54

B. Institutional and Market Structure...................................................................5

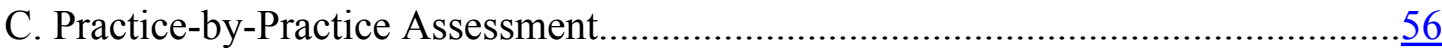

D. Recommended Action Plan and Authorities' Response to the Assessment ............

Tables

1. Observance of IMF's MFP Transparency Code-Banking Supervision ............................... $\underline{6}$

2. Summary Observance of IMF's MFP Transparency Code - Banking Supervision ............21

3. Recommended Action Plan to Improve Observance of IMF's MFP

Transparency Code - Banking Supervision........................................................22

4. Observance of IMF's MFP Transparency Code - Securities Market Supervision ..............25

5. Summary Observance of IMF's MFP Transparency Code-Securities

Market Supervision ..............................................................................................

6. Recommended Action Plan to Improve Observance of IMF's MFP Transparency

Code — Securities Market Supervision.................................................................. $\frac{40}{43}$

7. Observance of IMF's MFP Transparency Code—Deposit Insurance Funds .......................43

8. Summary Observance of IMF's MFP Transparency Code-Deposit Insurance Funds ..... $\underline{52}$

9. Recommended Action Plan to Improve Observance of IMF's MFP

Transparency Code - Deposit Insurance Funds....

10. Observance of IMF's MFP Transparency Code-Payment Systems Oversight.................. $\underline{56}$

11. Summary Observance of IMF's MFP Transparency

Code-Payment Systems Oversight.....

12. Recommended Action Plan to Improve Observance of IMF's MFP

Transparency Code-Payment Systems Oversight 


\section{GLOSSARY}

ACs Autonomous Communities (Comunidades Autónomas)

BE Bank of Spain (Banco de España)

BOE State Official Gazette (Boletin Oficial del Estado)

caja Savings banks (cajas de ahorros)

CNMV National Securities Market Commission (Comisión Nacional del Mercado de Valores)

DA disposición adicional

DGS Directorate General of Supervision

DGSFP Directorate General of Insurance and Pension Funds

ESCB European System of Central Banks

FESCO Forum of European Securities Commissions

FGDs Deposit Guarantee Funds (Fondos de Garantía de Depósitos)

GCG General Code of Conduct

LABE Law of Autonomy of the Bank of Spain (Law 13/1994)

LDI Law on Discipline and Intervention of Credit Institutions (Law 26/1988)

LIFFE London International Financial Futures Exchange

LMV Securities Market Law

LORCA Law on Governing Bodies of Savings Banks (Law 31/1985)

ME Ministry of Economy and Finance (Ministerio de Economía y Finanzas)

RIBE Internal Regulations of the Bank of Spain

SEPLAC Servicio Ejecutivo de la Comisión de Prevención de Blanqueo de Capitales e Infracciones Monetarias 


\section{BANKING SUPERVISION ${ }^{1}$}

\section{A. Information and Methodology Used for Assessment}

1. An evaluation of observance of good transparency practices relating to banking supervisory and regulatory policy was carried out as part of the Financial Sector Assessment Program (FSAP). The assessment was conducted against the IMF Code of Good Practices on Transparency in Monetary and Financial Policies (MFP Transparency Code). It was undertaken during June-July 2005 and covers primarily the Bank of Spain (BE); transparency in the institutional framework also cover other agencies with responsibilities in banking supervision and regulation (i.e., the Ministry of Economy and Finance-ME - and the Autonomous Communities). The assessment was based on (a) relevant laws; (b) information made available on the BE website; (c) information available in the BE's and bank supervision annual reports and other publications; (d) responses to a pre-FSAP questionnaire; (e) extensive discussions with officials of the financial agencies; and (f) discussions with commercial banks and bankers' associations.

2. The Spanish authorities cooperated fully with the assessment and provided all the necessary clarifications and documents.

\section{B. Institutional and Market Structure}

3. The Directorate General of Supervision (DGS) performs the supervisory function of the BE relating to banks. The DGS carries out these activities under the directions of the Governing Council on the legal basis of the Law of Autonomy of the Bank of Spain (Law 13/1994, LABE). The LABE specifies the responsibility to "supervise, in accordance with existing regulations, the solvency activities and compliance with specific regulations of credit institutions, and any other financial institution or market it has been called on to oversee, without prejudice to the prudential supervision of autonomous communities (ACs) in their areas of responsibility, and the cooperation between these autonomous communities and the Bank in performing such regional supervisory tasks." The Law on Discipline and Intervention of Credit Institutions (Law 26/1988 July 29, 1988, LDI), further defines the institutional framework, responsibility, and authority of the DGS. The Internal Regulations of the Bank of Spain (RIBE) are disclosed on the website.

4. Institutions currently under the supervision of the BE are commercial banks, savings banks, credit cooperatives, specialized credit institutions, and electronic money issuers. Subsidiaries and branches of foreign credit institution are also under BE supervision.

5. The Governing Council of the BE is composed of the Governor, the Deputy Governor, six members elected by the government, the Director General of Treasury and Financial Policy under the ME, and the Vice President of the National Securities Market

\footnotetext{
${ }^{1}$ The author of this assessment is Camilla Ferenius (Bank of Sweden). The assessment was carried out from June 22 to July 1, 2005.
} 
Commission (CNMV). BE director generals as well as a staff representative selected according to internal rules attend Council meetings in a nonvoting capacity. ${ }^{2}$

6. The Communications Department disseminates policy decisions and policy announcements, provides information on the operating framework and objectives, publishes texts of major speeches by senior officials, data, and research reports, arranges seminars and maintains contacts with the media. The BE's website (www.bde.es) contains general information, legislation and regulation, statistics, publications, and so on. It is available in both Spanish and English.

\section{Practice-by-Practice Assessment}

7. This detailed assessment recognizes that banking supervision and the legal and institutional framework differ from one country to another, as do the domestic circumstances. The assessment of observance with each practice of the MFP Transparency Code is based on existing laws, regulations, and practices. A five-part assessment system is used: Observed; broadly observed; partly observed; not observed; and not applicable: observed, implying full observance or with insignificant shortcomings; broadly observed, where minor weaknesses exist and these are not seen as being of a significant nature so as to raise serious doubts about the authority's ability to achieve the objective of that practice; partly observed, where shortcomings are sufficient to raise doubts about the authority's ability to achieve observance and which could affect the operational process and effectiveness of financial policies; not observed, where the practice is not being observed and no substantive progress has been recorded toward achieving the objectives of the practice; and not applicable, where, due to the country circumstances and the institutional and legal framework, the transparency practice is not applicable.

\footnotetext{
${ }^{2}$ For a complete description of the institutional and macro-prudential setting, see the Assessment of Compliance with the Basel Core Principles for Effective Banking Supervision in Spain.
} 


\section{Table 1. Observance of IMF's MFP Transparency Code—Banking Supervision}

\section{ClaRity OF ROLES, RESPONSIBILITIES, AND OBJECTIVES OF FinANCIAL AGENCIES RESPONSIBLE FOR} Financial Policies

The broad objective(s) and institutional framework of financial agencies should be clearly defined, preferably in relevant legislation or regulation.

Description

The BE's institutional framework is legislated in the Law of Autonomy of the Bank of Spain (Law 13/1994, LABE), where Art. 1 states that "The Bank is an institution under public law with its own legal personality and full public and private legal capacity. It shall pursue its activities and fulfill its objectives with autonomy from the administration, carrying out its functions as specified in this law and other legislation," and that "the Bank is an integral part of the European System of Central Banks (ESCB) and shall be subject to the provisions of the Treaty of the European Community ("Treaty") and to the Statutes of the ESCB."

According to the preamble to the LABE, "the new law balances the provisions of the Treaty on European Union with the mandates of our Constitution, and coordinates this equilibrium through various provisions. Article 7, for example, which defines the objectives towards which monetary policy should be directed, sets price stability as a priority objective, which is an essential, though admittedly not the sole, element of the «economic stability» referred to in Art. 40 of the Constitution. As long as it does not detract from this primary objective, monetary policy shall support the general economic policy of the government. In the light of Art. 97 of the Constitution, which gives the government responsibility for directing domestic and foreign policy, Art. 24 of the law assigns to the government the exclusive responsibility for appointing all members of the Bank's governing bodies. Art. 20 authorizes the Minister of the ME and the Secretary of State for the Economy to attend the meetings of the Bank Council as they deem necessary, and to submit motions to the Council as needed, thereby providing the government with an appropriate channel to expound its arguments even in areas in which the Bank can make independent decisions."

The Law on Discipline and Intervention of Credit Institutions (Law 26/1988, LDI) defines the institutional framework, responsibility, and authority related to banking supervision. Art. 43 bis (25): "Responsibility for overseeing and inspecting credit institutions shall rest with the Bank of Spain. These powers shall extend to any office or center inside or outside Spanish national territory and, inasmuch as required for the discharge of the functions entrusted to the Bank of Spain, to the companies belonging to the group of the affected credit institution. The Bank of Spain shall also be responsible for supervising consolidated groups of credit institutions, as provided in Law 13/1985, of May 25." Article 43 bis LDI also defines the role of the $\mathrm{BE}$ with regard of inspections in the case of branches of credit institutions authorized in other European Community member states.

The institutional framework, including the organization and functions of the DGS, is disclosed on the BE website under Functional Structure.

Regulatory responsibility for the financial system in Spain is principally held by the ME through the Directorate General of Treasury and Financial Policy. Only in specific areas are regulatory powers delegated to the BE through Royal Decrees (central government) and Orders (ministry). Within these areas the BE can issue Circulars. Article 3 LABE states "to correctly fulfill its other responsibilities, it may adopt the any regulations that it deems necessary to develop legislation for which it has been expressly empowered. These regulations shall be called "Circulares."

In addition, regional governments (the Autonomous Communities, ACs) have regulatory and supervisory powers with respect to saving banks located in their region. The statute of each AC and savings bank law specific to each AC establish the role of the autonomous communities in savings bank supervision and specify which agency within the regional government has 


\begin{tabular}{|c|c|}
\hline & responsibility for financial policy. \\
\hline Assessment & Observed. \\
\hline \multicolumn{2}{|l|}{ Comments } \\
\hline 5.1 .1 & The broad objective(s) of financial agencies should be publicly disclosed and explained. \\
\hline Description & $\begin{array}{l}\text { Art. } 7.2 \text { of LABE defines the broad objectives of the Bank of Spain "Without prejudice to its } \\
\text { main objective of maintaining price stability and fulfilling its duties as a member of the ESCB } \\
\text { in accordance with the terms of Article } 105.1 \text { of the Treaty, the Bank shall support the general } \\
\text { economic policy of the government." } \\
\text { Financial stability is currently not listed as an objective, but is mentioned in the extensive list of } \\
\text { functions of the central bank. Art. } 7.3 \text { states that the BE shall participate in the fulfillment of } \\
\text { the functions attributed to the ESCB: with section d) specifying "to promote the smooth } \\
\text { functioning of the payment system." Regarding the national level Art. } 5 \text { states that the Bank } \\
\text { shall, moreover, perform the following functions: "b) promote the smooth operation and the } \\
\text { stability of the financial system and, without prejudice to the terms of 3.d) above, of national } \\
\text { payment systems." The responsibility to supervise banking institutions is stated in Art } 7.6 . \\
\text { The objective of banking supervision is mentioned on the website /About us/ Functions of the } \\
\text { Bank of Spain /Banking Supervision/ in the text: "In order to help safeguard the financial } \\
\text { system and make it more stable, the Bank of Spain supervises (...)." Similarly, p. 76 of the } \\
\text { Memoria Anual de Supervisión 2003/Banking Supervisión 2003, mentions "(...) with the } \\
\text { principal objective to safeguard the stability of the financial system." Hence, information on the } \\
\text { main objective of banking supervision exists, but is neither easily accessible nor explained. } \\
\text { The legislation that establishes the objectives and functions of the BE is made public in the } \\
\text { State Official Gazette (BOE) and disclosed on the website under www.bde.es/legislation. } \\
\text { The ME as a regulator states on the website the role of "financial policy management and } \\
\text { development, along with drawing up and processing of provisions related to financial and credit } \\
\text { institutions, etc." The objective of the ACs supervision of saving banks is to make sure that } \\
\text { cajas comply with their laws and the regulations that the ACs are empowered to impose } \\
\text { according to that law. This is mentioned on the different websites in terms of responsibilities } \\
\text { (e.g., Valencia www.gva.es/ivf/). }\end{array}$ \\
\hline Assessment & Broadly observed. \\
\hline Comments & $\begin{array}{l}\text { Currently, the main objectives of the BE with regard to banking supervision are only briefly } \\
\text { mentioned in the annual report and the website and not explicitly in legislation. In addition, the } \\
\text { existing disclosure of the objectives should be more easily accessible and be explained, e.g., on } \\
\text { the Banking Supervision webpage. }\end{array}$ \\
\hline 5.1 .2 & $\begin{array}{l}\text { The responsibilities of the financial agencies and the authority to conduct financial policies } \\
\text { should be publicly disclosed. }\end{array}$ \\
\hline Description & $\begin{array}{l}\text { The functions of the central bank are contained in Art. } 7 \text { of LABE: } \\
\text { "1. The Bank shall be responsible for exercising the functions assigned to it by this law and } \\
\text { any other functions which it might be assigned by other laws. } \\
\text { 2. Without prejudice to its main objective of maintaining price stability and fulfilling its duties } \\
\text { as a member of the ESCB in accordance with the terms of Art. } 105.1 \text { of the Treaty, the Bank } \\
\text { shall support the general economic policy of the government (...). } \\
\text { 3. The Bank shall participate in the fulfillment of the following basic functions attributed to the } \\
\text { ESCB: (...) } \\
\text { 6. The Bank shall supervise, in accordance with existing regulations, the solvency activities } \\
\text { and compliance with specific regulations of credit institutions, and any other financial }\end{array}$ \\
\hline
\end{tabular}




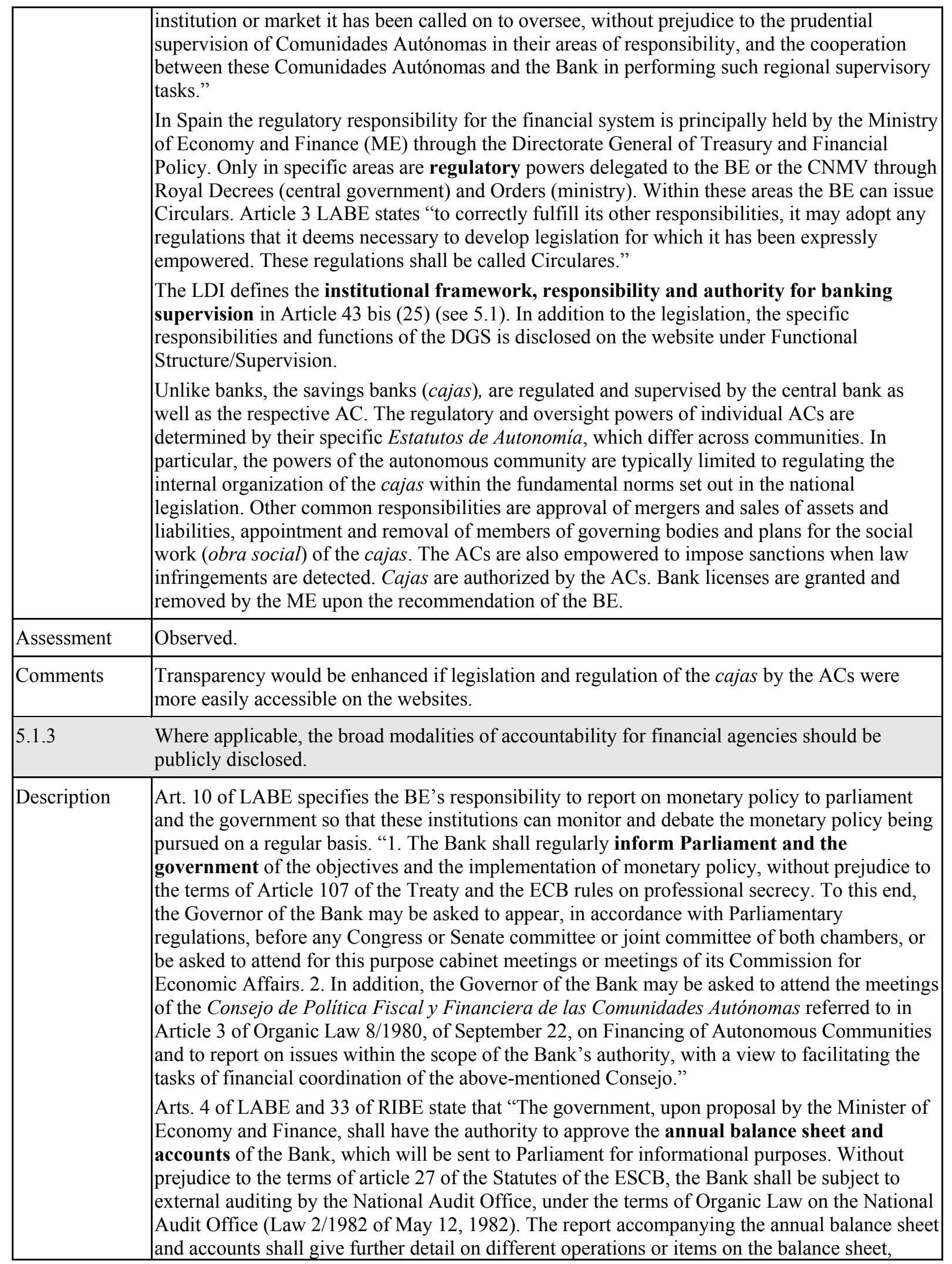




\begin{tabular}{|c|c|}
\hline & $\begin{array}{l}\text { according to their characteristics. In particular, the Bank's contributions to the Deposit } \\
\text { Guarantee Funds shall be detailed, as will any loans or other operations transacted for the } \\
\text { benefit of any other institution or person not on an arm's-length basis, or which in any other } \\
\text { way involve loss of profit or losses for the Bank. In such cases the amount of such loss of profit } \\
\text { or losses shall be specified." Art. } 21.1 \text { c states that "the Governing Council shall approve, at the } \\
\text { proposal of the Executive Commission, the annual report of the Bank and, as relevant, any other } \\
\text { reports which the Bank must submit to Parliament, to the government or to the Economy and } \\
\text { Finance Minister." }\end{array}$ \\
\hline & $\begin{array}{l}\text { The BE also publishes an annual complaints report (Memoria del Servicio de Reclamaciones). } \\
\text { This accountability framework applies to all of the BE's areas of responsibility, including } \\
\text { banking supervision. }\end{array}$ \\
\hline & $\begin{array}{l}\text { In addition, the BE has to issue a special annual report on the supervisory function (Memoria de } \\
\text { la Supervisión Bancaria en España). The Financial Law (Law } 44 / 2002, \mathrm{DA} 2^{\mathrm{a}} \text {, 2) specifies that } \\
\text { this should contain information on the activities and the efficiency of these activities and an } \\
\text { internal audit report. This should be approved by the governing board of the BE and sent to the } \\
\text { government and parliament (Cortes Generales). The LDI (Art. 8) states that "The Bank of } \\
\text { Spain shall send an annual report to the Spanish parliament on the actions which have given rise } \\
\text { to very serious sanctions and to interventions or substitutions under Title III of this Law." } \\
\text { Under Art. 32, "1 The intervention or substitution measures referred to by the preceding article } \\
\text { shall be resolved by the Bank of Spain, giving a reasoned explanation of their adoption to the } \\
\text { Minister of Economy and Finance." }\end{array}$ \\
\hline & $\begin{array}{l}\text { All the annual reports, as well as the speeches of the governor, are publicly available on the BE } \\
\text { website. }\end{array}$ \\
\hline Assessment & Observed. \\
\hline Comments & \\
\hline 5.1 .4 & $\begin{array}{l}\text { Where applicable, the procedures for appointment, terms of office, and any general criteria for } \\
\text { removal of the heads and members of the governing bodies of financial agencies should be } \\
\text { publicly disclosed. }\end{array}$ \\
\hline Description & $\begin{array}{l}\text { Arts. } 24 \text { and } 25 \text { of LABE establish the procedure for appointment, the terms, and the criteria for } \\
\text { removal of the heads and members of the governing bodies. }\end{array}$ \\
\hline & $\begin{array}{l}\text { Art. } 24 \text { states that the BE Governor shall be appointed by the King following a proposal by the } \\
\text { head (President) of government. Nominees shall be Spanish and have recognized competence in } \\
\text { monetary and/or banking matters. Prior to the appointment of the Governor, the Minister of the } \\
\text { ME shall appear before the relevant parliamentary committee under the terms envisaged in } \\
\text { Art. } 203 \text { of the Spanish Parliamentary Internal Regulations, to report on the proposed candidate. } \\
\text { The Deputy Governor shall be appointed by the government following a proposal by the } \\
\text { Governor and must meet the same conditions as the Governor. The six elected Council } \\
\text { members shall be appointed by the government following a proposal by the Minister of the ME, } \\
\text { after consultation with the Governor of the BE. They must be Spanish and have recognized } \\
\text { competence in the area of economy or law. They serve a six-year term and can be reappointed } \\
\text { once (Article } 25.2 \text { of the LABE). }\end{array}$ \\
\hline & $\begin{array}{l}\text { Art. } 25 \text { defines the terms of office and criteria for dismissal of members of governing bodies. } \\
\text { "The terms of office of the Governor and the Deputy Governor will be simultaneous, for a } \\
\text { period of six years, and non-renewable for the same position. Elected Council members will } \\
\text { serve a six-year term and may be reappointed once." The terms of office of each Council } \\
\text { member are set on an individual basis and do not need to coincide with those of the Governor } \\
\text { and Deputy Governor, or of other Council members. The Governor, the Deputy Governor, and } \\
\text { elected Council members shall leave office for the following reasons: }\end{array}$ \\
\hline & a. "Expiration of their terms of office. \\
\hline
\end{tabular}




\begin{tabular}{|c|c|}
\hline & $\begin{array}{l}\text { b. Resignation, which will take effect once the government is notified or, in the case of a } \\
\text { member of the Executive Commission, when the Governing Council is notified. } \\
\text { c. Reaching } 70 \text { years of age. } \\
\text { d. Dismissal decided by the government, due to permanent incapacity to perform their } \\
\text { functions, serious lack of compliance with their obligations, incompatibility that may have } \\
\text { arisen during the term of office, or prosecution for deliberate crimes." } \\
\text { Art. } 26 \text { defines the incompatibilities. } \\
\text { 1. "The Governor and the Deputy Governor shall be subject to the system of incompatibilities } \\
\text { applicable to senior officials. Their posts shall also be incompatible with the exercise of any } \\
\text { public or private profession or activity, unless these are inherent to their status or are imposed } \\
\text { as part of their role as representatives of the Bank. Once their term of office ends, over the next } \\
\text { two years they may not engage in any professional activity linked to credit institutions or } \\
\text { securities markets. } \\
\text { 2. Elected Council members may not be involved in professional activities linked to credit } \\
\text { institutions of any type, to securities markets or to private financial institutions during their } \\
\text { terms in office. Serving on the Bank Council is compatible with teaching and research } \\
\text { activities." These aspects are also elaborates in the RIBE. } \\
\text { There are no special rules for the Director General of Banking Supervision. However, Art. } 6 \\
\text { (secrecy) and Art } 26.2 \text { (other professional activities) apply also to all general directors (LABE } \\
\text { Art. 30). These aspects are also elaborated in the RIBE. } \\
\text { All the mentioned legislation and RIBE have been made public in the State Official Gazette } \\
\text { (BOE) and are available on the BE website. }\end{array}$ \\
\hline Assessment & Observed. \\
\hline Comments & \\
\hline 5.2 & The relationship between financial agencies should be publicly disclosed. \\
\hline Description & $\begin{array}{l}\text { Supervision is carried out by the Bank of Spain for credit institutions (LABE), the CNMV for } \\
\text { the securities markets (Securities Market Law, Law 24/1988, LMV), and the Directorate } \\
\text { General of Insurance and Pension Funds (DGSFP) under the State Secretary of Economy for } \\
\text { insurance companies and pension funds. The ACs have regulatory and supervisory powers with } \\
\text { respect to saving banks located in their region. The laws clearly articulate the responsibilities of } \\
\text { the BE and the ME with respect to the supervision of the solvency, performance, and } \\
\text { compliance with specific regulations governing credit institutions. At the same time, each AC } \\
\text { operates under its own legal framework. } \\
\text { Art. } 7.8 \text { of LABE_states that the "Bank may establish relationships with other central banks, } \\
\text { with financial supervisory authorities and financial institutions in other countries, and with } \\
\text { international monetary and financial organizations. It may also establish relationships with } \\
\text { public financial institutions and regional financial supervisory authorities." The possibility to } \\
\text { sign national agreements between supervisors is recognized in the Financial Law (DA } 2 \\
\text { Law } 44 / 2002 \text { ), which points out an obligation of cooperation between the BE, the CNMV and } \\
\text { the ME to harmonize supervision practices and criteria and to exchange relevant information. } \\
\text { The relationship between the BE and the CNMV is also recognized in Art. } 88 \text { of LMV. The } \\
\text { cooperation between banking and insurance supervisors relating to conglomerates (grupos } \\
\text { mixtos) is described in Art. } 12.3 \text { of Law } 13 / 1992 \text {. } \\
\text { The BE, the CNMV, and the ME also cooperate and exchange information (Arts. 17 of LMV } \\
\text { and } 20 \text { of LABE) through cross-membership in governing bodies (the BE deputy governor is a } \\
\text { member in the CNMV council, and the Director General of the Treasury and Financial Policy } \\
\text { and the CNMV vice president are members of the governing council of the BE). In addition, the } \\
\text { BE has signed agreements with the CNMV (June 9, 2004) and the DGSFP (March 12, 2004). } \\
\text { This is published in the } 2004 \text { annual report on supervision. }\end{array}$ \\
\hline
\end{tabular}




\begin{tabular}{|c|c|}
\hline & $\begin{array}{l}\text { Art. } 43 \text { bis. } 8 \text { of LDI, Art. } 7.6 \text { and } 8 \text { of LABE, and DA } 1^{\mathrm{a}} \text { a. } 3 \text { of the Law on Governing Bodies } \\
\text { of Savings Banks (Law } 31 / 1985 \text {, LORCA) relate to the relationship with the Autonomous } \\
\text { Communities (Comunidades Autónomas) with respect to latter's regulatory and supervisory } \\
\text { authority on saving banks. The BE shall supervise, in accordance with existing regulations, the } \\
\text { solvency activities and compliance with specific regulations of credit institutions, and any other } \\
\text { financial institution or market it has been called on to oversee, without prejudice to the } \\
\text { prudential supervision of autonomous communities in their areas of responsibility, and the } \\
\text { cooperation between these autonomous communities and the Bank in performing such regional } \\
\text { supervisory tasks." The statute of each AC establishes the objective and role of the ACs in } \\
\text { savings bank supervision. }\end{array}$ \\
\hline Assessment & Broadly observed. \\
\hline Comments & $\begin{array}{l}\text { While the cooperation between the BE and the ACs appears to be effective, it is advisable to } \\
\text { minimize those circumstances where overlapping national and regional legal frameworks may } \\
\text { cause conflicts, particularly in the application of supervisory or sanctioning authority. }\end{array}$ \\
\hline 5.3 & $\begin{array}{l}\text { The role of oversight agencies with regard to payment systems should be publicly } \\
\text { disclosed. }\end{array}$ \\
\hline \multicolumn{2}{|l|}{ Description } \\
\hline Assessment & Not applicable. \\
\hline Comments & See separate assessment of transparency in payment system oversight. \\
\hline 5.3 .1 & $\begin{array}{l}\text { The agencies overseeing payment systems should promote the timely public disclosure of } \\
\text { general policy principles (including risk management policies) that affect the robustness of } \\
\text { systemically important payment systems. }\end{array}$ \\
\hline \multicolumn{2}{|l|}{ Description } \\
\hline Assessment & Not applicable. \\
\hline Comments & See separate assessment of transparency in payment system oversight. \\
\hline 5.4 & $\begin{array}{l}\text { Where financial agencies have oversight responsibilities for self-regulatory organizations } \\
\text { (e.g., payment systems), the relationship between them should be publicly disclosed. }\end{array}$ \\
\hline \multicolumn{2}{|l|}{ Description } \\
\hline Assessment & Not applicable. \\
\hline Comments & $\begin{array}{l}\text { The agencies in charge of banking regulation and supervision have no oversight responsibility } \\
\text { for self-regulatory organizations. }\end{array}$ \\
\hline 5.5 & $\begin{array}{l}\text { Where self-regulatory organizations are authorized to perform part of the regulatory and } \\
\text { supervisory process, they should be guided by the same good transparency practices } \\
\text { specified for financial agencies. }\end{array}$ \\
\hline \multicolumn{2}{|l|}{ Description } \\
\hline Assessment & Not applicable \\
\hline Comments & $\begin{array}{l}\text { The agencies in charge of banking regulation and supervision have no oversight responsibility } \\
\text { for self-regulatory organizations. }\end{array}$ \\
\hline \multicolumn{2}{|r|}{ VI. OPEN Process FOR Formulating AND REPORTING OF FinANCIAL POLICIES } \\
\hline 6.1 & $\begin{array}{l}\text { The conduct of policies by financial agencies should be transparent, compatible with } \\
\text { confidentiality considerations and the need to preserve the effectiveness of actions by } \\
\text { regulatory and oversight agencies. }\end{array}$ \\
\hline
\end{tabular}




\begin{tabular}{|c|c|}
\hline \multirow[t]{2}{*}{ Description } & $\begin{array}{l}\text { The LDI specifies the measures and actions to be taken by banking supervisors. The BE } \\
\text { elaborates and publishes the annual report on supervision, the annual report of the BE, and the } \\
\text { annual report on complaints, which are all available on the website/publications. In the annual } \\
\text { report on supervision, all activities are described in detail and a section on new prudential } \\
\text { regulation is included. In } 2003 \text { the BE started reporting on its banking supervision and } \\
\text { regulation activities also in the management report section of the BE's annual report. In } \\
\text { addition, the functions of the BE with regard to banking supervision are described on the BE } \\
\text { website/About us/Functions/Banking Supervision. }\end{array}$ \\
\hline & $\begin{array}{l}\text { The ME as a regulator discloses all regulation on the website www.meh.es as well as } \\
\text { information on regulation in progress. Information on the role of ACs in caja supervision is } \\
\text { however somewhat scattered. }\end{array}$ \\
\hline Assessment & Broadly observed. \\
\hline Comments & $\begin{array}{l}\text { Transparency would be enhanced if legislation and regulation relating to ACs were more easily } \\
\text { accessible on the websites. }\end{array}$ \\
\hline 6.1 .1 & $\begin{array}{l}\text { The regulatory framework and operating procedures governing the conduct of financial policies } \\
\text { should be publicly disclosed and explained. }\end{array}$ \\
\hline Description & $\begin{array}{l}\text { The regulatory framework governing the conduct of financial policies is disclosed in the LABE } \\
\text { Art. 7.6. The LDI specifies the measures and actions to be taken by banking supervisors. } \\
\text { Art. } 3 \text { LABE states that the Bank shall adopt the necessary regulations for the exercise of its } \\
\text { functions. These regulations are called "Circulares Monetarias" and "Circulares" and are both } \\
\text { published in the BOE. The legal and regulatory framework is posted on the website (LABE, } \\
\text { LDI, RIBE). In addition, BE functions pertaining to banking supervision are described on the } \\
\text { BE website /About us/Functions/Banking Supervision. The operating procedures were } \\
\text { thoroughly explained in the } 2001 \text { annual report on supervision (in Spanish only). Finally, the } \\
\text { concept of risk-based supervision is described in the } 2003 \text { annual report on supervision (in } \\
\text { Spanish only). }\end{array}$ \\
\hline Assessment & Observed. \\
\hline Comments & $\begin{array}{l}\text { It is recommended to post on the website the extensive material contained in the } 2001 \text { annual } \\
\text { report on supervision, and consider translating it into English. }\end{array}$ \\
\hline 6.1 .2 & $\begin{array}{l}\text { The regulations for financial reporting by financial institutions to financial agencies should be } \\
\text { publicly disclosed. }\end{array}$ \\
\hline Description & $\begin{array}{l}\text { BE Circular } 4 / 2004 \text { regulates public and confidential information provided to the supervisor } \\
\text { and models of financial statements and has adapted of the Spanish accounting regime to the } \\
\text { IASB. The regulations are well known and made public. Changes in this regulation are made } \\
\text { after public debate with the affected sectors (see } 6.4 \text { ) and are made public by the BE in its } \\
\text { publications and on the website. See http://www.bde.es/normativa/normas.htm }\end{array}$ \\
\hline Assessment & Observed. \\
\hline \multicolumn{2}{|l|}{ Comments } \\
\hline 6.1 .3 & $\begin{array}{l}\text { The regulations for the operation of organized financial markets (including those for issuers of } \\
\text { traded financial instruments) should be publicly disclosed. }\end{array}$ \\
\hline \multicolumn{2}{|l|}{ Description } \\
\hline Assessment & Not applicable \\
\hline Comments & $\begin{array}{l}\text { The regulations for the operation of organized financial markets (including those for issuers of } \\
\text { traded financial instruments) are publicly disclosed by the CNMV. }\end{array}$ \\
\hline
\end{tabular}




\begin{tabular}{|c|c|}
\hline 6.1 .4 & $\begin{array}{l}\text { Where financial agencies charge fees to financial institutions, the structure of such fees should } \\
\text { be publicly disclosed. }\end{array}$ \\
\hline \multicolumn{2}{|l|}{ Description } \\
\hline Assessment & Not applicable. \\
\hline Comments & The BE as a supervisor does not charge fees to financial institutions. \\
\hline 6.1 .5 & $\begin{array}{l}\text { Where applicable, formal procedures for information sharing and consultation between } \\
\text { financial agencies (including central banks), domestic and international, should be publicly } \\
\text { disclosed. }\end{array}$ \\
\hline \multirow[t]{5}{*}{ Description } & For relations with other authorities, see 5.2 . \\
\hline & $\begin{array}{l}\text { DA } 2^{\text {a }} .3 \text { of the Financial Law (Law 44/2002) establishes the possibility of cooperation between } \\
\text { national supervisors (bank, securities, insurance). The BE has signed agreements with the } \\
\text { CNMV ( } 9.6 .2004 \text { ) and the DGSFP (12.3.04). This is made public in the } 2004 \text { Annual Report of } \\
\text { the Supervision. In addition, it requires cooperation with supervisors in other countries and, in } \\
\text { particular, signed memoranda of understanding (Art. } 6.1 \text { RDL } 1298 / 1986 \text {. EU Directives). } \\
\text { Articles } 43.2 \text { and } 58.2 \text { of LDI require consultations by the BE with relevant foreign supervisors } \\
\text { in case of opening of subsidiaries in Spain and acquisition of significant holdings in Spanish } \\
\text { credit entities by European credit entities. The BE has signed various agreements and } \\
\text { memoranda of understanding on information exchange with other supervisors, especially in } \\
\text { Latin America. The agreements are made public in press releases, and on the BE website. From } \\
2003 \text { the Annual Report of the Bank of Spain also contains a Management Report including a } \\
\text { description on agreements signed during the year. }\end{array}$ \\
\hline & $\begin{array}{l}\text { The BE sends monthly reports to each AC, including extensive information on the cajas in their } \\
\text { regions (balance sheets, P\&L statements, sanctions, result of supervisory actions and on-site } \\
\text { examination findings etc). Occasionally the BE and the ACs do joint on-site examinations. In } \\
\text { addition article } 43.8 \text { LDI and Article } 3 \text { LORCA establish the possibility to sign agreements } \\
\text { between the BE and the ACs. However, there are no formal arrangements for information } \\
\text { exchange. }\end{array}$ \\
\hline & $\begin{array}{l}\text { Another aspect refers to the relationship between the supervisors of the payment systems and } \\
\text { the banking supervisors. In } 2001 \text { the BE signed an EU protocol on cooperation between } \\
\text { agencies responsible for payment system oversight and for banking supervision, in its double } \\
\text { role as responsible for both. In } 2003 \text {, the BE signed a similar memorandum establishing high- } \\
\text { level principles for cooperation in crisis management between national central banks and } \\
\text { banking supervisors in the European Union. The signing of both memoranda were } \\
\text { communicated to the public through ECB press releases, translated into Spanish by the BE and } \\
\text { posted on both the ECB and BE websites. The press releases include an explanation of the need } \\
\text { for and content of the memoranda. Moreover, Spain entered into a cooperative agreement } \\
\text { between central credit registers with other European countries. These agreements were made } \\
\text { public in the management report section of the annual report the corresponding year. }\end{array}$ \\
\hline & $\begin{array}{l}\text { The BE and the ECB exchange accounting information pursuant to Orientation BCE/2002/NP9 } \\
\text { on the procedures of elaboration of financial reports in the ECB system. The Orientation is not } \\
\text { publicly available. In summary it is, among other things, a calendar for sending information } \\
\text { from the central banks to the ECB. }\end{array}$ \\
\hline Assessment & Broadly observed. \\
\hline Comments & $\begin{array}{l}\text { In order to get an observed rating, the content of the MoUs should be made public, not only } \\
\text { their existence. Knowledge of consultation procedures among agencies provides the public with } \\
\text { assurances that financial agencies have established mechanisms to deal with regulatory issues } \\
\text { and financial problems that cut across the mandates of different agencies. }\end{array}$ \\
\hline
\end{tabular}




\begin{tabular}{|c|c|}
\hline 6.2 & $\begin{array}{l}\text { Significant changes in financial policies should be publicly announced and explained in a } \\
\text { timely manner. }\end{array}$ \\
\hline Description & $\begin{array}{l}\text { The BE publicly announces and explains significant changes in financial policies (banking } \\
\text { legislation and regulation) through the Annual Report, the website, notas informativas, monthly } \\
\text { publications, and press releases. Major changes are published in the BOE the day following } \\
\text { such decisions. The BE has a Q\&A system on the website where questions from the public are } \\
\text { answered. }\end{array}$ \\
\hline Assessment & Observed. \\
\hline \multicolumn{2}{|l|}{ Comments } \\
\hline 6.3 & $\begin{array}{l}\text { Financial agencies should issue periodic public reports on how their overall policy } \\
\text { objectives are being pursued. }\end{array}$ \\
\hline \multirow[t]{2}{*}{ Description } & $\begin{array}{l}\text { The BE elaborates a specific Annual Report on Supervision (Memoria de la Supervisión } \\
\text { Bancaria en España), including its functions, activities and procedures, and including an } \\
\text { internal audit report on the appropriateness of decisions taken. This report (2001, 2002, and } \\
\text { 2003) is complemented with notes on the financial stability and official periodic notes on } \\
\text { relevant subjects such as structure and evolution of the institutions, regulatory changes, and } \\
\text { disciplinary proceedings initiated and resolved. }\end{array}$ \\
\hline & $\begin{array}{l}\text { Banking supervision activities are also described in the management report section of the BE's } \\
\text { annual report. The section describes how financial policy objectives were pursued, including } \\
\text { supervisory measures such as placing under administration and imposing sanctions. }\end{array}$ \\
\hline Assessment & Observed. \\
\hline \multicolumn{2}{|l|}{ Comments } \\
\hline 6.4 & $\begin{array}{l}\text { For proposed substantive technical changes to the structure of financial regulations, there } \\
\text { should be a presumption in favor of public consultations, within an appropriate period. }\end{array}$ \\
\hline \multirow[t]{4}{*}{ Description } & $\begin{array}{l}\text { The legislative framework requires public consultations with affected sectors. The legislation is } \\
\text { posted on the BE website. }\end{array}$ \\
\hline & $\begin{array}{l}\text { Arts. } 3.2 \text { of LABE and } 8.5 \text { of RIBE specify that "in the case of the 'Circulares' the affected } \\
\text { parties should receive a hearing." Art. } 24 \text { of the Law on Government (Law 50/1997, del } \\
\text { Gobierno), establishes the procedures of elaboration of regulation (like the BE circulars) in } \\
\text { what refers to how the elaboration should involve the affected sectors. }\end{array}$ \\
\hline & $\begin{array}{l}\text { The BE has used public consultations for proposed substantive technical changes in the } \\
\text { structure of financial regulations. The BE's website has a specific section reserved for SEBC } \\
\text { consultations, available from the main page. These consultations are held through a public } \\
\text { notification and give a certain period (usually not less than three months) to make written } \\
\text { comments. The received comments are made public at the end of the consultation period. }\end{array}$ \\
\hline & $\begin{array}{l}\text { The BE has strengthened transparency with the elaboration of BE Circular 4/2004, which } \\
\text { adopts international accounting rules. To do so, the BE published in July and October } 2004 \text { the } \\
\text { drafts on the website, before formally approving the regulation in December. Market } \\
\text { participants expressed appreciation of the authorities' efforts to involve the affected parties in } \\
\text { the regulatory process, even if the consultative period is sometimes considered too short. }\end{array}$ \\
\hline Assessment & Observed. \\
\hline Comments & \\
\hline
\end{tabular}


VII. Public Availability of Information on Financial Policies

\begin{tabular}{|c|c|}
\hline 7.1 & $\begin{array}{l}\text { Financial agencies should issue a periodic public report on the major developments of the } \\
\text { sector(s) of the financial system for which they carry designated responsibility. }\end{array}$ \\
\hline \multirow[t]{4}{*}{ Description } & $\begin{array}{l}\text { The annual report on supervision includes a chapter on "the structure and development of the } \\
\text { entities under BE supervision" (http://www.bde.es/informes/be/supervi/2003/cap1.pdf). Twice a } \\
\text { year the BE also publishes a financial stability report } \\
\text { (www.bde.es/informes/be/estfin/estfin.htm). }\end{array}$ \\
\hline & $\begin{array}{l}\text { In annual report of the be analyzes financial development in Spain, intermediaries, and markets } \\
\text { (www.bde.es/informes/be/infanu/2003/cap5.pdf). }\end{array}$ \\
\hline & $\begin{array}{l}\text { Finally, the BE also analyzes the entities it supervises and publish the analyses in the relevant } \\
\text { Economic Bulletins (Boletines Económicos). }\end{array}$ \\
\hline & All the publications are available on the BE website. \\
\hline Assessment & Observed. \\
\hline \multicolumn{2}{|l|}{ Comments } \\
\hline 7.2 & $\begin{array}{l}\text { Financial agencies should seek to ensure that, consistent with confidentiality } \\
\text { requirements, there is public reporting of aggregate data related to their jurisdictional } \\
\text { responsibilities on a timely and regular basis. }\end{array}$ \\
\hline \multirow[t]{2}{*}{ Description } & $\begin{array}{l}\text { Arts. } 15 \text { and } 16 \text { of Decree Law on the Nationalization and Reorganization of BE (DL18/62, de } \\
\text { Nacionalización y Reorganización del BE) and Art 7.5.f of LABE state that the BE shall } \\
\text { "compile and publish statistics related to its functions and assist the ECB in the compilation of } \\
\text { the statistical information needed for the fulfillment of the ESCB's functions." }\end{array}$ \\
\hline & $\begin{array}{l}\text { All information on financial entities is made public in aggregated form, consistent with } \\
\text { confidentiality requirements. This is done in the monthly Boletín Estadistico, as well as in the } \\
\text { yearly Memoria de Supervisión. In addition, aggregated statistical information is published in } \\
\text { the Financial Stability Report and in the Annual Report of the BE, all available at the BE } \\
\text { website/Estadísticas. }\end{array}$ \\
\hline Assessment & Observed. \\
\hline \multicolumn{2}{|l|}{ Comments } \\
\hline 7.3 & $\begin{array}{l}\text { Where applicable, financial agencies should publicly disclose their balance sheets on a } \\
\text { preannounced schedule and, after a predetermined interval, publicly disclose information } \\
\text { on aggregate market transactions. }\end{array}$ \\
\hline \multirow[t]{2}{*}{ Description } & $\begin{array}{l}\text { Orientation BCE/2002/10 on the legal regime for accounting and elaboration of financial } \\
\text { reports in the European System of Central Banks (ESCB) includes fundamental accounting } \\
\text { principles, defines assets and liabilities, rules for the composition of the balance and valuation } \\
\text { criteria. }\end{array}$ \\
\hline & $\begin{array}{l}\text { BE's economic regime is established in Art. } 4 \text { of LABE, including procedures for elaboration, } \\
\text { approval, and publication of the annual accounts. "The government, upon proposal by the } \\
\text { Economy and Finance Minister, shall have the authority to approve the annual balance sheet } \\
\text { and accounts of the Bank, which will be sent to Parliament for information purposes. Without } \\
\text { prejudice to the terms of Article } 27 \text { of the Statutes of the ESCB, the Bank shall be subject to } \\
\text { external auditing by the National Audit Tribunal, under the terms of Organic Law } 2 / 1982 \text {, of } \\
\text { May 12, on the National Audit Tribunal. The report accompanying the annual balance sheet and } \\
\text { accounts shall give further detail on different operations or items on the balance sheet, } \\
\text { according to their characteristics. In particular, the Bank's contributions to the Deposit } \\
\text { Guarantee Funds shall be detailed, as will any loans or other operations transacted for the } \\
\text { benefit of any other institution or person not on an arm's-length basis, or which in any other }\end{array}$ \\
\hline
\end{tabular}




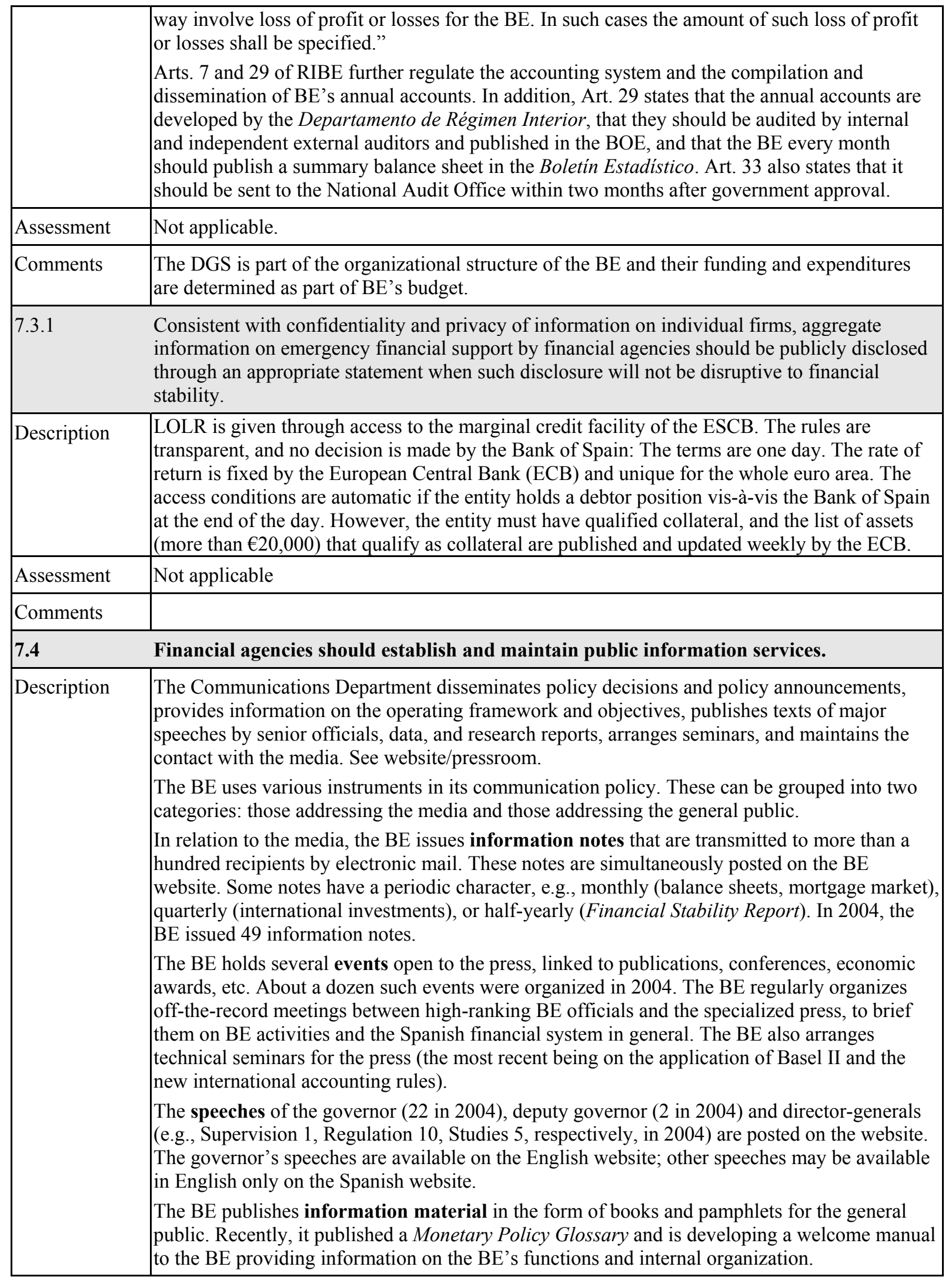




\begin{tabular}{|c|c|}
\hline & $\begin{array}{l}\text { Addressing the same general public, the BE is developing a special section on the website in } \\
\text { which it offers all necessary practical information that a bank client needs in daily contacts with } \\
\text { financial entities. In addition, the BE website contains an email address, telephone, and fax } \\
\text { numbers to receive questions from the general public. The website includes a wide range of } \\
\text { information. The publications relating to banking supervision and regulation and financial } \\
\text { markets can be found in Spanish in the Banking Supervision section. However, the English } \\
\text { language website for banking supervision is not updated and does not include any publications. } \\
\text { General information on banking supervision in Spain can be found in the section About us/ } \\
\text { functions/ banking supervision, but not on the Banking Supervision section. } \\
\text { A permanent information source regarding BE policies and the situation in the financial sector } \\
\text { is the BE Publications Service. See 7.4.1. }\end{array}$ \\
\hline Assessment & Broadly observed. \\
\hline Comments & $\begin{array}{l}\text { General information on banking supervision in Spain can only be found in the section About us/ } \\
\text { functions/banking supervision on the website. This information, including the disclosure of the } \\
\text { objectives of banking supervision should be more easily accessible and be explained, e.g., on } \\
\text { the Banking Supervision main webpage. The English version website for banking supervision } \\
\text { should be updated and include the same references to publications as the Spanish version. } \\
\text { Where the publications only exists in Spanish, a reference "in Spanish only" could be used, as } \\
\text { is normal in the other areas of the website. It is recommended to better coordinate the English } \\
\text { and Spanish websites, e.g., with respect to published speeches. }\end{array}$ \\
\hline 7.4 .1 & $\begin{array}{l}\text { Financial agencies should have a publications program, including a periodic public report on } \\
\text { their principal activities issued at least annually. }\end{array}$ \\
\hline \multirow[t]{3}{*}{ Description } & $\begin{array}{l}\text { The publications program was established in the Resolution March 28, } 2000 \text { of the BE } \\
\text { governing board. }\end{array}$ \\
\hline & $\begin{array}{l}\text { The BE has a publications program with periodic reports including a monthly evaluation of the } \\
\text { general economic situation (Boletín Económico), an evaluation of national financial stability } \\
\text { (Estabilidad Financiera), official statistics (Boletín Estadístico, Cuentas Financieras de la } \\
\text { Economía Española, Balanza de Pagos, Central de Balances, Indicadores Económicos), bank } \\
\text { supervision activities (Memoria de la Supervisión Bancaria), public debt management } \\
\text { operations (Informe Anual del Mercado de Deuda, Boletines Diarios del Mercado de Deuda } \\
\text { Pública) and complaints (Memoria del Servicio de Reclamaciones). }\end{array}$ \\
\hline & $\begin{array}{l}\text { In addition, the BE annual report, published in June, include a management report explaining } \\
\text { the main activities of the institution. This report is accompanied by the governor's speech in } \\
\text { which the economic and financial situation is evaluated, as well as the principal recent changes } \\
\text { in the activities of the bank. All these publications are distributed to the press and to more than } \\
3,200 \text { subscribers, and posted on the website. }\end{array}$ \\
\hline Assessment & Observed. \\
\hline \multicolumn{2}{|l|}{ Comments } \\
\hline 7.4 .2 & $\begin{array}{l}\text { Senior financial agency officials should be ready to explain their institution's objective(s) and } \\
\text { performance to the public, and have a presumption in favor of releasing the text of their } \\
\text { statements to the public. }\end{array}$ \\
\hline \multirow[t]{2}{*}{ Description } & $\begin{array}{l}\text { Art. } 10 \text { of LABE states that " } 1 \text {. The Bank shall regularly inform Parliament and the government } \\
\text { of the objectives and the implementation of monetary policy (...). To this end, the Governor of } \\
\text { the Bank may be asked to appear, in accordance with Parliamentary regulations, before any } \\
\text { Congress or Senate committee or joint committee of both chambers, or be asked to attend for } \\
\text { this purpose cabinet meetings or meetings of its Commission for Economic Affairs. }\end{array}$ \\
\hline & $\begin{array}{l}\text { 2. In addition, the Governor of the Bank may be asked to attend the meetings of the Consejo de } \\
\text { Politica Fiscal y Financiera de las Comunidades Autónomas (...) and to report on issues within }\end{array}$ \\
\hline
\end{tabular}




\begin{tabular}{|c|c|}
\hline & $\begin{array}{l}\text { the scope of the Bank's authority, with a view to facilitating the tasks of financial coordination } \\
\text { of the above-mentioned Consejo." } \\
\text { In practice, the Governor appears regularly before parliament, usually three times a year. In } \\
\text { addition, its common that the Governor, Deputy Governor or Director-Generals make public } \\
\text { speeches. See 7.4. }\end{array}$ \\
\hline Assessment & Observed. \\
\hline Comments & $\begin{array}{l}\text { It is recommended that the English and Spanish websites be better coordinated, e.g., with } \\
\text { respect to published speeches. }\end{array}$ \\
\hline 7.5 & $\begin{array}{l}\text { Texts of regulations and any other generally applicable directives and guidelines issued by } \\
\text { financial agencies should be readily available to the public. }\end{array}$ \\
\hline Description & $\begin{array}{l}\text { The circulars (CBE) that the BE issues as part of its functions (Arts. 3.1. and } 16 \text { of LABE; } \\
\text { Art. } 7 \text { of RIBE) are published in the BOE (Arts. } 3 \text { of LABE and } 8.9 \text { of RIBE). Legislation } \\
\text { affecting the BE (as well as financial entities) is regularly updated on the BE website, in the } \\
\text { section "Legislation." }\end{array}$ \\
\hline Assessment & Observed. \\
\hline Comments & $\begin{array}{l}\text { Due to the many modifications of BE circulars it is recommended that the overall organization } \\
\text { of BE circulars be updated in order to improve transparency. }\end{array}$ \\
\hline 7.6 & $\begin{array}{l}\text { Where there are deposit insurance guarantees, policyholder guarantees, and any other } \\
\text { client asset protection schemes, information on the nature and form of such protections, } \\
\text { the operating procedures, how the guarantee is financed, and the performance of the } \\
\text { arrangement should be publicly disclosed. }\end{array}$ \\
\hline \multirow[t]{2}{*}{ Description } & $\begin{array}{l}\text { RDL 4/1980, RDL } 18 / 1982 \text {, and RD 2606/1996 contain the legal regime for deposit insurance; } \\
\text { RD 948/2001 for investor protection. }\end{array}$ \\
\hline & $\begin{array}{l}\text { In the website of the Deposit Guarantee Fund (www.fgd.es) detailed information can be found } \\
\text { on the deposit guarantee. The BE has also a website section dedicated to deposit insurance. }\end{array}$ \\
\hline Assessment & Not applicable. \\
\hline Comments & This is not the responsibility of the banking supervisor. \\
\hline 7.7 & $\begin{array}{l}\text { Where financial agencies oversee consumer protection arrangements (such as dispute } \\
\text { settlement processes), information on such arrangements should be publicly disclosed. }\end{array}$ \\
\hline \multirow[t]{3}{*}{ Description } & $\begin{array}{l}\text { Arts. } 22-31 \text { of the Financial Law (Law 44/2002) establish the protection regime for users of } \\
\text { financial services. Art. } 22 \text { creates a Commission (Comisionado) for the Protection of Clients of } \\
\text { Financial Services to attend complaints, reclamations and give advice to the users of financial } \\
\text { services. Art. } 26 \text { states the obligation for the Commission to produce and publish an annual } \\
\text { report including a summary of consultations and complaints; Art. } 18 \text { of Order } 303 / 2004 \\
\text { develops regulations for this Commission. }\end{array}$ \\
\hline & $\begin{array}{l}\text { Article } 31 \text { of the Financial Law } 44 / 2002 \text { and Art. } 8.4 \text { of Order ECO/734/2004 give the BE } \\
\text { authority to regulate the consumer protection arrangements. Chapter II of BE Circular } 8 / 1990 \\
\text { defines the organization and functions of the BE Complaints Service and Arts. } 5 \text { e) and } 48.2 \\
\text { of LDI establish sanction for lack of transparency in regard to the operations of credit entities. } \\
\text { Credit entities should have organs for the resolution of conflicts with clients, and should inform } \\
\text { about this in their annual reports. The BE Complaints Service issues an annual report, available } \\
\text { on the website, where the criteria followed in the treatment of conflicts between the bank clients } \\
\text { and credit entities are described. }\end{array}$ \\
\hline & $\begin{array}{l}\text { Information on the rates of interest charged by credit institutions is available on the BE's } \\
\text { website, including a "Clients corner" section. }\end{array}$ \\
\hline
\end{tabular}




\begin{tabular}{|c|c|}
\hline Assessment & Observed. \\
\hline \multicolumn{2}{|l|}{ Comments } \\
\hline \multicolumn{2}{|r|}{ VIII. ACCOUNTABILITY AND ASSURANCES OF INTEGRITY BY FINANCIAL AGENCIES } \\
\hline 8.1 & $\begin{array}{l}\text { Officials of financial agencies should be available to appear before a designated public } \\
\text { authority to report on the conduct of financial policies, explain the policy objective(s) of } \\
\text { their institution, describe their performance in pursuing their objective(s), and, as } \\
\text { appropriate, exchange views on the state of the financial system. }\end{array}$ \\
\hline \multirow[t]{3}{*}{ Description } & $\begin{array}{l}\text { Article } 10 \text { of LABE states that " } 1 \text {. The Bank shall regularly inform Parliament and the } \\
\text { government of the objectives and the implementation of monetary policy (...). To this end, the } \\
\text { Governor of the Bank may be asked to appear, in accordance with Parliamentary regulations, } \\
\text { before any Congress or Senate committee or joint committee of both chambers, or be asked to } \\
\text { attend for this purpose cabinet meetings or meetings of its Commission for Economic Affairs. }\end{array}$ \\
\hline & $\begin{array}{l}\text { 2. In addition, the Governor of the Bank may be asked to attend the meetings of the Consejo de } \\
\text { Politica Fiscal y Financiera de las Comunidades Autónomas (...) and to report on issues within } \\
\text { the scope of the Bank's authority, with a view to facilitating the tasks of financial coordination } \\
\text { of the above-mentioned Consejo." }\end{array}$ \\
\hline & $\begin{array}{l}\text { In practice, the Governor appears regularly before parliament, usually three times a year. In } \\
2004 \text { the governor appeared before the Budget Commissions of Congress (Deputies, October } 13 \\
\text { and Senate, November 24), as well as before the Economy and Finance Commission (Deputies, } \\
\text { June 30) to discuss economic conditions and policy. The appearances are made public in the } \\
\text { Diario de Sesiones del Congreso. The BE, usually through the Governor or a Director General, } \\
\text { informs on the objectives and the performance of its functions. Public speeches by the } \\
\text { Governor, Deputy Governor, and Directors General are posted on the website and in some cases } \\
\text { included in other BE publications. }\end{array}$ \\
\hline Assessment & Observed. \\
\hline \multicolumn{2}{|l|}{ Comments } \\
\hline 8.2 & $\begin{array}{l}\text { Where applicable, financial agencies should publicly disclose audited financial statements } \\
\text { of their operations on a preannounced schedule. }\end{array}$ \\
\hline Description & $\begin{array}{l}\text { Arts. } 4.2 \text { of LABE and } 29 \text { and } 32 \text { of RIBE establish the obligation to submit the BE accounts, } \\
\text { already audited by the Internal Audit Department, to the Audit Committee, external auditors, } \\
\text { and the National Audit Office. The Governing Council submits the annual accounts for } \\
\text { government approval, upon proposal by the Minister of the Economy. The annual accounts of } \\
\text { the BE, including notes to the accounts and the audit report, are included in the Annual Report } \\
\text { of the BE, issued in June. }\end{array}$ \\
\hline Assessment & Not applicable. \\
\hline Comments & $\begin{array}{l}\text { The DGS is part of the organizational structure of the BE; its funding and expenditures are } \\
\text { determined as part of the BE's budget. }\end{array}$ \\
\hline 8.2 .1 & $\begin{array}{l}\text { Financial statements, if any, should be audited by an independent auditor. Information on } \\
\text { accounting policies and any qualification to the statements should be an integral part of the } \\
\text { publicly disclosed financial statements. }\end{array}$ \\
\hline Description & $\begin{array}{l}\text { Art. } 29 \text { and following of RIBE and } 4.2 \text { of LABE state that the BE is subject to independent } \\
\text { external auditing pursuant to Art. } 27 \text { of the statutes of the ESCB. }\end{array}$ \\
\hline & $\begin{array}{l}\text { The external auditors report (see, for instance, the } 2003 \text { annual report of the BE, p. 226) } \\
\text { contains information on accounting policies and qualifications to the statements. The annual } \\
\text { accounts include balance sheet, income statement, notes to the accounts, and the statement of }\end{array}$ \\
\hline
\end{tabular}




\begin{tabular}{|c|c|}
\hline & $\begin{array}{l}\text { the independent auditor. Contributions to the Deposit insurance fund and all operations not at } \\
\text { market value are detailed separately in the report (see 7.3.1). }\end{array}$ \\
\hline Assessment & Not applicable. \\
\hline Comments & $\begin{array}{l}\text { The DGS is part of the organizational structure of the BE; its funding and expenditures are } \\
\text { determined as part of the BE's budget. }\end{array}$ \\
\hline 8.2 .2 & $\begin{array}{l}\text { Internal governance procedures necessary to ensure the integrity of operations, including } \\
\text { internal audit arrangements, should be publicly disclosed. }\end{array}$ \\
\hline \multirow[t]{2}{*}{ Description } & $\begin{array}{l}\text { DA } 2^{\mathrm{a}} \text { of the Financial Law established a series of measures to improve the efficiency and } \\
\text { quality of supervision, including issuance of an annual report on supervision that should contain } \\
\text { an internal audit of the functioning of BE's governing bodies, with a focus on their decisions } \\
\text { and the suitability of the normative procedures applied. }\end{array}$ \\
\hline & $\begin{array}{l}\text { Articles } 29 \text { and } 32 \text { of RIBE regulate the Internal Audit Department, and Arts. } 79-88 \text { its internal } \\
\text { control functions. The By-laws of the Internal Audit Department, approved by BE's Executive } \\
\text { Commission on November } 28,2001 \text {, are made public on the website/About us/Functional } \\
\text { Structure/Internal Audit Department. The activities of the internal audit are also disclosed in the } \\
\text { management report section of the annual report, under the heading "Internal Organization and } \\
\text { Administration." }\end{array}$ \\
\hline Assessment & Observed. \\
\hline \multicolumn{2}{|l|}{ Comments } \\
\hline 8.3 & $\begin{array}{l}\text { Where applicable, information on the operating expenses and revenues of financial } \\
\text { agencies should be publicly disclosed annually. }\end{array}$ \\
\hline Description & $\begin{array}{l}\text { Arts. } 4 \text { of LABE and } 28 \text { of RIBE specify that the budget, once approved by the Governing } \\
\text { Council, shall be forwarded to the government, which will submit it to parliament for approval. } \\
\text { "The budget shall be prospective in nature, and shall not be consolidated with other State public } \\
\text { sector budgets. The government, upon proposal by the Economy and Finance Minister, shall } \\
\text { have the authority to approve the annual balance sheet and accounts of the Bank, which will be } \\
\text { sent to Parliament for informational purposes (...). The report accompanying the annual } \\
\text { balance sheet and accounts shall give further detail on different operations or items on the } \\
\text { balance sheet, according to their characteristics (...) or which in any other way involve loss of } \\
\text { profit or losses for the Bank. In such cases the amount of such loss of profit or losses shall be } \\
\text { specified." See notes of the loss and profit account on p. } 118 \text { of the Annual Report } 2003 \text {. }\end{array}$ \\
\hline Assessment & Not applicable. \\
\hline Comments & $\begin{array}{l}\text { The DGS is part of the organizational structure of the BE; its funding and expenditures are } \\
\text { determined as part of the BE's budget. }\end{array}$ \\
\hline 8.4 & $\begin{array}{l}\text { Standards for the conduct of personal financial affairs of officials and staff of financial } \\
\text { agencies and rules to prevent exploitation of conflicts of interest, including any general } \\
\text { fiduciary obligation, should be publicly disclosed. }\end{array}$ \\
\hline Description & $\begin{array}{l}\text { Art. } 28 \text { of LABE. Limitations applicable to members of the Governing Council. } \\
\text { 1. Members of the Governing Council shall refrain from acquiring or owning goods or rights } \\
\text { and from engaging in any activities that might compromise their independence and impartiality } \\
\text { in the exercise of their responsibilities, cause conflicts of interest, or permit them to use } \\
\text { privileged information. In particular, they must contractually entrust to a financial } \\
\text { institution registered with the CNMV the administration of any tradable securities or financial } \\
\text { assets of which they, their non-separated spouses, or dependent children are owners. The said } \\
\text { institution shall administer these assets subject only to the general indications of profitability } \\
\text { and risk established in the contract, and may not request nor receive investment instructions }\end{array}$ \\
\hline
\end{tabular}




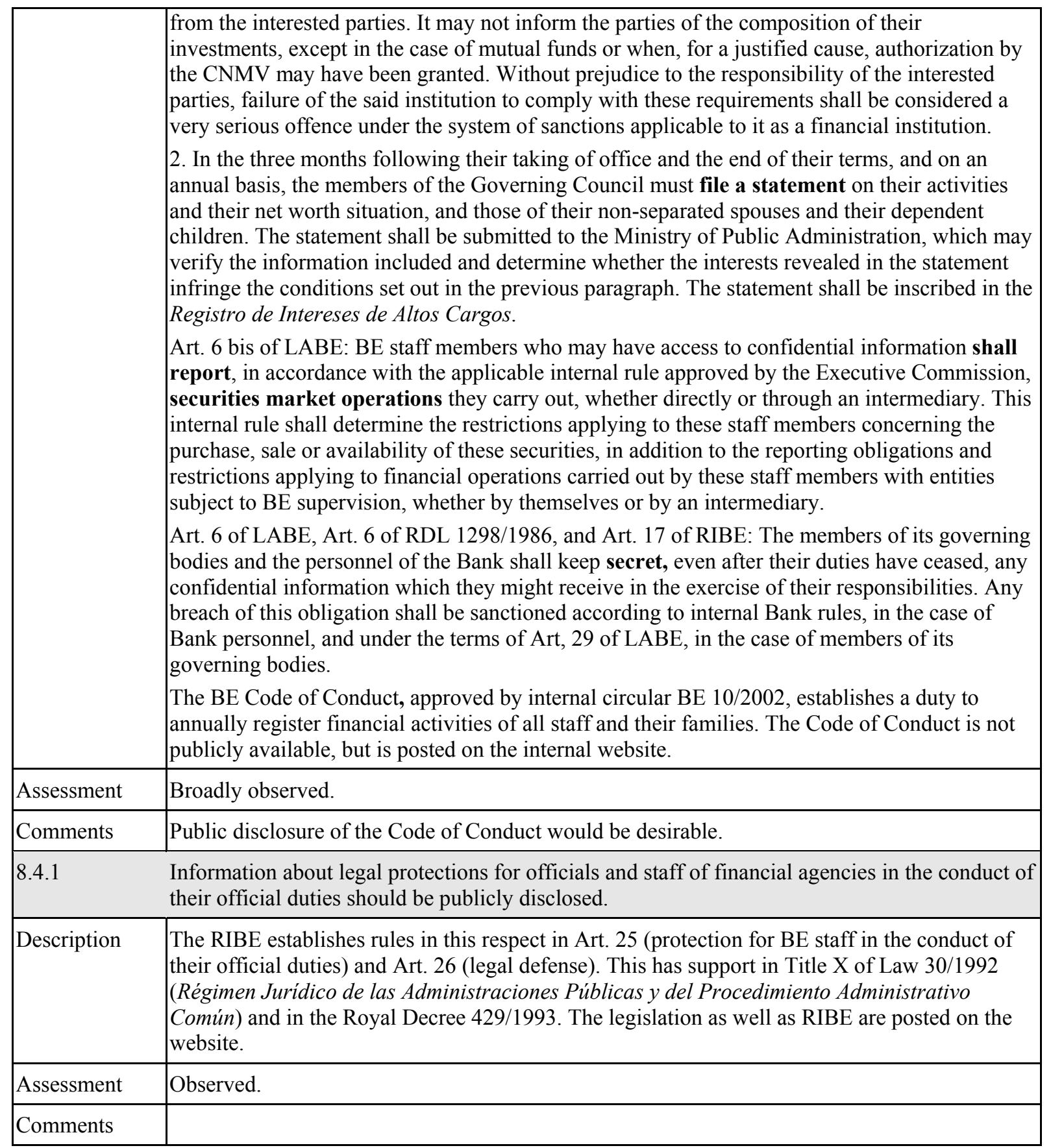


Table 2. Summary Observance of IMF's MFP Transparency Code—Banking Supervision

\begin{tabular}{|c|c|c|}
\hline \multirow{2}{*}{$\begin{array}{l}\text { Assessment } \\
\text { Grade }\end{array}$} & \multicolumn{2}{|r|}{ Practices Grouped by Assessment Grade } \\
\hline & Count & List \\
\hline Observed & 20 & $\begin{array}{l}\text { 5.1; 5.1.2; 5.1.3; 5.1.4; 6.1.1; 6.1.2; 6.2; 6.3; 6.4; 7.1; 7.2; 7.4.1; 7.4.2; 7.5; } \\
7.7 ; 8.1 ; 8.2 .2 ; 8.4 .1\end{array}$ \\
\hline Broadly observed & 4 & $5.1 .1 ; 5.2 ; 6.1 ; 6.1 .5 ; 7.4 ; 8.4$ \\
\hline \multirow{2}{*}{\multicolumn{3}{|c|}{$\frac{\text { Partly observed }}{\text { Non-observed }}$}} \\
\hline & & \\
\hline Not applicable & 12 & $5.3 ; 5.3 .1 ; 5.4 ; 5.5 ; 6.1 .3 ; 6.1 .4 ; 7.3 ; 7.3 .1 ; 7.6 ; 8.2 ; 8.2 .1 ; 8.3$ \\
\hline
\end{tabular}

\section{Recommended Action Plan and Authorities' Response to the Assessment}

\section{Recommended action plan}

8. The DGS adheres to almost all of the practices of the Code of Good Practices on Transparency in Financial Policies. To further refine transparency, the following may be considered:

- Disclosure of the objectives, regulatory framework, and operating procedures for banking supervision could be made more easily accessible and explained, for instance through posting on the banking supervision main webpage. Translation into English could also be considered. General information on banking supervision can currently be found only in the section About us/ functions/ banking supervision.

- $\quad$ The English-language website for banking supervision should be updated regularly and include the same references to publications as the Spanish version. Where the publications only exists in Spanish, a reference (e.g., "in Spanish only") could be used, as is normal elsewhere on BE website. The English- and Spanish-language websites could be better coordinated, for instance with respect to published speeches.

- $\quad$ The Bank of Spain as should make public the content of all MoUs with other agencies, not only the year in which they were signed. Knowledge of consultation procedures with domestic and international agencies provides the public with assurances that financial agencies have established mechanisms to deal with regulatory issues and problems that cut across their mandates.

- $\quad$ Public disclosure of the internal Code of Conduct would strengthen the BE's transparency and confidence on the part of political authorities, market participants, and the general public in the care with which the BE performs its functions.

- $\quad$ As BE circulars have been subject to several modifications, it would be desirable that the overall organization of BE circulars be updated to improve the transparency in the regulatory framework. 


\section{Table 3. Recommended Action Plan to Improve Observance of IMF's MFP Transparency Code Practices-Banking Supervision}

\begin{tabular}{|c|c|}
\hline Reference Practice & Recommended Action \\
\hline \multicolumn{2}{|l|}{$\begin{array}{l}\text { V. Clarity of Roles, } \\
\text { Responsibilities, and Objectives } \\
\text { of Financial Agencies } \\
\text { Responsible for Financial } \\
\text { Policies }\end{array}$} \\
\hline $\begin{array}{l}\text { 5.1.1 The broad objective(s) of } \\
\text { financial agencies should be } \\
\text { publicly disclosed and explained. }\end{array}$ & $\begin{array}{l}\text { Currently, the main objectives of the BE with regard to banking } \\
\text { supervision are only briefly mentioned in the Annual Report and the } \\
\text { website. Disclosure of the objectives should be more easily accessible, for } \\
\text { instance though posting the DGS main webpage. }\end{array}$ \\
\hline $\begin{array}{l}5.2 \text { The relationship between } \\
\text { financial agencies should be } \\
\text { publicly disclosed. }\end{array}$ & $\begin{array}{l}\text { While the cooperation between the BE and the ACs appears to be effective, } \\
\text { it is advisable to minimize those circumstances where overlapping national } \\
\text { and regional legal frameworks may create uncertainty on the respective } \\
\text { authority of the BE and the ACs. }\end{array}$ \\
\hline \multicolumn{2}{|l|}{$\begin{array}{l}\text { VI. Open Process for } \\
\text { Formulating and Reporting of } \\
\text { Financial Policies }\end{array}$} \\
\hline $\begin{array}{l}6.1 \text { The conduct of policies by } \\
\text { financial agencies should be } \\
\text { transparent. }\end{array}$ & $\begin{array}{l}\text { Transparency would be enhanced if legislation and regulation relating to } \\
\text { ACs were more easily accessible. }\end{array}$ \\
\hline $\begin{array}{l}\text { 6.1.5 Where applicable, formal } \\
\text { procedures for information sharing } \\
\text { and consultation between financial } \\
\text { agencies (including central banks), } \\
\text { domestic and international, should } \\
\text { be publicly disclosed. }\end{array}$ & $\begin{array}{l}\text { The content of MoUs should be made public, not only the year they were } \\
\text { signed. Knowledge of consultation procedures between domestic and/or } \\
\text { international agencies provides the public with assurances that financial } \\
\text { agencies have established mechanisms to deal with regulatory issues and } \\
\text { problems that cut across their mandates. }\end{array}$ \\
\hline \multicolumn{2}{|l|}{$\begin{array}{l}\text { VII. Public Availability of } \\
\text { Information on Financial Policies }\end{array}$} \\
\hline $\begin{array}{l}\text { 7.4 Financial agencies should } \\
\text { establish and maintain public } \\
\text { information services. }\end{array}$ & $\begin{array}{l}\text { General information on banking supervision can only be found in the } \\
\text { section About us/functions/banking supervision. This information should } \\
\text { be more easily accessible, for instance through posting on the DGS main } \\
\text { webpage. The English-language website for banking supervision should be } \\
\text { updated regularly and include the same references to publications as the } \\
\text { Spanish version. Where publications only exist in Spanish, this should be } \\
\text { explicitly mentioned, as is normal in the other areas of the website. The } \\
\text { English- and Spanish-language websites should be better coordinated, e.g., } \\
\text { with respect to published speeches. }\end{array}$ \\
\hline \multicolumn{2}{|l|}{$\begin{array}{l}\text { VIII. Accountability and } \\
\text { Assurance of Integrity by } \\
\text { Financial Agencies }\end{array}$} \\
\hline $\begin{array}{l}\text { 8.4 Standards for the conduct of } \\
\text { personal financial affairs of } \\
\text { officials and staff of financial } \\
\text { agencies and rules to prevent } \\
\text { exploitation of conflicts of interest, } \\
\text { including any general fiduciary } \\
\text { obligation, should be publicly } \\
\text { disclosed. }\end{array}$ & $\begin{array}{l}\text { Public disclosure of the Code of Conduct would strengthen confidence in } \\
\text { the care with which the BE performs its multiple functions. }\end{array}$ \\
\hline
\end{tabular}




\section{Authorities' response to the assessment}

9. The authorities are in broad agreement with the assessment. However, as regards cooperation with the ACs (point 5.2), they note that the State and the ACs have regulatory, supervisory and sanctioning powers within their corresponding areas of responsibilities, and no overlapping arises between the national and the regional legal framework. Each AC operates under its own legal framework. At the same time, the laws clearly articulate the responsibilities of the $\mathrm{BE}$ and $\mathrm{ME}$ with respect to the supervision of the solvency, performance, and compliance with specific regulations governing credit institutions.

10. The Bank of Spain has already initiated an action plan to address the transparency recommendations. In the first phase, they will include:

- Improving consistency between the Spanish and English versions of their web page.

- $\quad$ Adding institutional information, such as the internal code of conduct for employees of the $\mathrm{BE}$ and the members of the Governing Council (Consejo de Gobierno) including their CVs.

- $\quad$ Reorganizing and developing the website contents under bank supervision.

\section{SeCURITIES MARKeTS SUPERVISION}

\section{A. Information and Methodology Used for Assessment}

11. An evaluation of the National Securities Market Commission (Comisión Nacional del Mercado de Valores, CNMV) observance of good transparency practices relating to securities market supervision was carried out as part of the Fund Financial Sector Assessment Program (FSAP). The assessment was conducted against the IMF Code of Good Practices on Transparency in Monetary and Financial Policies (MFP Transparency Code). The assessment was undertaken during June-July 2005 based on (a) relevant laws;

(b) information made available on the CNMV website; (c) information available in the CNMV's and the Securities Market Annual Reports and other publications; (d) responses to a pre-FSAP questionnaire; e) extensive discussions with CNMV officials; and (f) discussions with the stock exchange and market associations. The Spanish authorities cooperated fully with the assessment and provided all the necessary clarifications and documents.

\section{B. Institutional and Market Structure}

12. The CNMV is the agency in charge of supervision and inspection of the Spanish stock markets and the activities of participants in those markets. The institutional framework for the CNMV is stated in the Securities Market Law (Ley de Mercado de Valores 24/1988, LMV). 
13. The purpose of the CNMV is "to ensure the transparency of the securities markets, the correct formation of the prices on these markets and the protection of investors by promoting disclosure of any information necessary in order to attain these ends." In order to ensure transaction security and the solvency of the system, the CNMV also exercises prudential supervision over collective investment schemes, broker-dealers and dealers, and portfolio management companies.

14. The CNMV is governed by a board consisting of a president and a vice president, who shall be appointed by the government, the Director General of Treasury and Financial Policy (of the ME), the Deputy Governor of the Bank of Spain, and three commissioners appointed by the Minister of Economy and Finance from among persons of "acknowledged competence on securities market matters."

15. Each year, the CNMV shall present a report on its activities and on the situation of the organized financial markets to the Parliamentary Committee on Economics, Trade and Finance. These reports are made public.

16. The Directorate of Research and Statistics disseminates policy decisions and policy announcements, provides information on the operating framework and objectives, data, consumer information, and research reports, and maintains contacts with the media. The CNMV has a website (www.cnmv.es) containing general information, legislation and regulation, statistics, publications, and so on. The website is available in both Spanish and English.

\section{Practice-by-Practice Assessment}

17. The detailed assessment recognizes that securities market supervision and the legal and institutional framework differ from one country to another, as do the domestic circumstances. The assessment of observance with each practice of the MFP Transparency Code is based on existing laws, regulations, and practices. A five-part assessment system is used: Observed; broadly observed; partly observed; not observed; and not applicable:

observed, implying full observance or with insignificant shortcomings; broadly observed, where minor weaknesses exist and these are not seen as being of a significant nature so as to raise serious doubts about the authority's ability to achieve the objective of that practice; partly observed, where shortcomings are sufficient to raise doubts about the authority's ability to achieve observance and which could affect the operational process and effectiveness of financial policies; not observed, where the practice is not being observed and no substantive progress has been recorded toward achieving the objectives of the practice; and not applicable, where, due to the country circumstances and the institutional and legal framework, the transparency practice is not applicable.

\footnotetext{
${ }^{3}$ For a complete description of the institutional and macroprudential setting, see the assessment of observance of IOSCO Objectives and Principles of Securities Regulation in Spain.
} 


\section{Table 4. Observance of IMF's MFP Transparency Code-Securities Market Supervision}

\begin{tabular}{|c|c|}
\hline \multicolumn{2}{|c|}{$\begin{array}{l}\text { V. ClaRity OF Roles, ResPonsibilities, AND OBJECTIVES OF FINANCIAL AGENCIES RESPONSIBLE FOR } \\
\text { FINANCIAL POLICIES }\end{array}$} \\
\hline 5.1 & $\begin{array}{l}\text { The broad objective(s) and institutional framework of financial agencies should be clearly } \\
\text { defined, preferably in relevant legislation or regulation. }\end{array}$ \\
\hline \multirow[t]{3}{*}{ Description } & $\begin{array}{l}\text { The institutional framework for the CNMV is stated in the Capital Markets Law (Law 24/1988, } \\
\text { Ley de Mercado de Valores, LMV). Its Art. } 13 \text { states that the CNMV "is entrusted with the } \\
\text { supervision and surveillance of the securities markets and of the trading activities of all } \\
\text { individuals and legal persons in these markets, the exercise of the power to sanction them, and } \\
\text { other duties attributed to it by this Law." }\end{array}$ \\
\hline & $\begin{array}{l}\text { Art.14 establishes that the CNMV "is a public law entity with independent legal status and full } \\
\text { public and private legal capacity, which shall be governed by the provisions of this Law and the } \\
\text { regulations that complete or implement it. (...) With regard to the National Securities Market } \\
\text { Commission, the Government and the Ministry of Economy shall exercise the powers conferred } \\
\text { upon them by this Law, with strict respect for its sphere of autonomy." }\end{array}$ \\
\hline & $\begin{array}{l}\text { The CNMV is governed by a board, which consists of a president and a vice president } \\
\text { appointed by the government based on a proposal by the ME, the Director General of Treasury } \\
\text { and Financial Policy, the deputy governor of the BE, and three commissioners appointed by the } \\
\text { Minister of the ME from among persons of "acknowledged competence on securities market } \\
\text { matters" (Art. 17). }\end{array}$ \\
\hline Assessment & Observed. \\
\hline \multicolumn{2}{|l|}{ Comments } \\
\hline 5.1 .1 & The broad objective(s) of financial agencies should be publicly disclosed and explained. \\
\hline \multirow[t]{2}{*}{ Description } & $\begin{array}{l}\text { Art. } 13 \text { of LMV specifies the broad objective and activities by pointing out that the CNMV } \\
\text { "shall seek to ensure the transparency of the securities markets, the correct formation of prices } \\
\text { on these markets, and the protection of investors by promoting disclosure of any information } \\
\text { necessary in order to attain these ends." }\end{array}$ \\
\hline & $\begin{array}{l}\text { The legislation for securities markets is posted on the website. The objectives are further } \\
\text { disclosed and described in the annual report of the CNMV and on the CNMV website, in the } \\
\text { section What is the CNMV? }\end{array}$ \\
\hline Assessment & Observed. \\
\hline \multicolumn{2}{|l|}{ Comments } \\
\hline 5.1 .2 & $\begin{array}{l}\text { The responsibilities of the financial agencies and the authority to conduct financial policies } \\
\text { should be publicly disclosed. }\end{array}$ \\
\hline \multirow[t]{2}{*}{ Description } & $\begin{array}{l}\text { Art. } 84.1 \text { of LMV defines the persons and firms subject to the regime of surveillance, } \\
\text { supervision, and sanction for which the CNMV is responsible. }\end{array}$ \\
\hline & $\begin{array}{l}\text { The functions of the CNMV are described in Art. 13: "The National Securities Market } \\
\text { Commission shall seek to ensure the transparency of the securities markets, the correct } \\
\text { formation of prices on these markets, and the protection of investors by promoting disclosure of } \\
\text { any information necessary in order to attain these ends. (...) The National Securities Market } \\
\text { Commission shall advise the Government and the Ministry of Economy and Finance and, as } \\
\text { appropriate, the equivalent bodies of the Autonomous Communities on matters relating to } \\
\text { securities markets, at the request of such bodies or on its own initiative. It may also propose to } \\
\text { those entities such procedures or regulations relating to securities markets as it may deem } \\
\text { necessary." }\end{array}$ \\
\hline
\end{tabular}




\begin{tabular}{|c|c|}
\hline & $\begin{array}{l}\text { In Spain the regulatory responsibility for the financial system is principally held by the ME } \\
\text { through the Directorate General of Treasury and Financial Policy. Only in specific areas are } \\
\text { regulatory powers delegated to the BE or CNMV through Royal Decrees (central government) } \\
\text { and Orders (ministry). Within these areas the CNMV can issue Circulars. Pursuant to Art. 15, } \\
\text { "in order to fully exercise the powers conferred upon it by this Law, the National Securities } \\
\text { Market Commission may issue any provisions required to implement and enforce the rules } \\
\text { contained in the Royal Decrees approved by the Government or in Orders issued by the } \\
\text { Ministry of Economy and Finance, provided that such statutory instruments expressly empower } \\
\text { it to do so." } \\
\text { The imposition of sanctions for minor and serious infringements rests with the CNMV, while } \\
\text { the imposition of sanctions for very serious infringements rests with the Minister the ME based } \\
\text { on a proposal by the CNMV (Art. 97). }\end{array}$ \\
\hline Assessment & Observed. \\
\hline Comments & \\
\hline 5.1 .3 & $\begin{array}{l}\text { Where applicable, the broad modalities of accountability for financial agencies should be } \\
\text { publicly disclosed. }\end{array}$ \\
\hline Description & $\begin{array}{l}\text { Art. } 13 \text { of LMV establishes that the CNMV "shall draw up and publish an annual report } \\
\text { describing its activities and the general condition of the securities markets. Each year, the } \\
\text { CNMV shall present a report on its activities and on the situation of the organized financial } \\
\text { markets to the Parliamentary Committee on Economics, Trade and Finance. The President of } \\
\text { the National Securities Market Commission shall appear before the aforementioned } \\
\text { Parliamentary Committee to respond to questions on the report as often as the Parliament may } \\
\text { require." } \\
\text { Finally, the economic and financial supervision of the CNMV is performed by the State } \\
\text { Comptroller's Office, through the National Audit Office, which is disclosed in legislation. } \\
\text { All legislation related to the CNMV and the securities market is posted on the CNMV } \\
\text { website/legislation. }\end{array}$ \\
\hline Assessment & Observed. \\
\hline Comments & \\
\hline 5.1 .4 & $\begin{array}{l}\text { Where applicable, the procedures for appointment, terms of office, and any general criteria for } \\
\text { removal of the heads and members of the governing bodies of financial agencies should be } \\
\text { publicly disclosed. }\end{array}$ \\
\hline Description & $\begin{array}{l}\text { The CNMV is governed by a board whose composition is defined in Art. } 17 \text { of LMV, which } \\
\text { also contains the appointment criteria. "The Board shall consist of the following: } \\
\text { a. A president and a vice-president, who shall be appointed by the government from among } \\
\text { persons of acknowledged competence in securities market matters, on the basis of } \\
\text { proposals by the Ministry of Economy and Finance. } \\
\text { b. The Director General of the Treasury and Financial Policy and the Deputy Governor of the } \\
\text { Bank of Spain; holders of those positions are automatically members of the Board. } \\
\text { c. Three Commissioners appointed by the Minister of Economy and Finance from among } \\
\text { persons of acknowledged competence on securities market matters." } \\
\text { Terms: Art. } 19 \text { establishes that "the President, Vice-President, and Commissioners envisaged in } \\
\text { Article 17.c) shall hold office for four years. Upon expiration, they may be re-appointed for one } \\
\text { further term only." } \\
\text { Grounds for removal are specified in Art. 20: "The President and Vice-President shall be } \\
\text { removed from office for the following causes: Expiration of their term of office, resignation } \\
\text { accepted by the Government, removal by the Government due to serious breach of their }\end{array}$ \\
\hline
\end{tabular}









\begin{tabular}{|c|c|}
\hline & $\begin{array}{l}\text { The CNMV has an oversight role in combination with other supervisory authorities as stated in } \\
\text { the LMV (as modified by the Financial Law). Iberclear's regulations shall be approved by both } \\
\text { BE and CNMV, but supervision, inspection, and sanctions are responsibility of the CNMV. } \\
\text { Article 44.bis.4 of LMV establishes that Iberclear "shall be governed by this Law and its } \\
\text { secondary legislation and by a Regulation to be approved by the Minister of Economy on the } \\
\text { basis of a report by the National Securities Market Commission, the Bank of Spain. and the } \\
\text { Autonomous Regional Governments empowered to regulate securities trading venues by their } \\
\text { Statutes of Autonomy." } \\
\text { The supervisory powers over Iberclear are disclosed in the CNMV Annual Report on Activities, } \\
\text { and on the Iberclear website (www.iberclear.es). }\end{array}$ \\
\hline Assessment & Observed. \\
\hline \multicolumn{2}{|l|}{ Comments } \\
\hline 5.3 .1 & $\begin{array}{l}\text { The agencies overseeing payment systems should promote the timely public disclosure of } \\
\text { general policy principles (including risk management policies) that affect the robustness of } \\
\text { systemically important payment systems. }\end{array}$ \\
\hline Description & $\begin{array}{l}\text { Article 44.bis of LMV, which establishes Iberclear, states that the regulation governing this } \\
\text { organization should include procedures to assure the delivery of securities and payments, as } \\
\text { well as the guarantees required by participants. The regulation should "be approved by the } \\
\text { Minister of Economy on the basis of a report by the National Securities Market Commission, } \\
\text { the Bank of Spain and the Autonomous Communities empowered to regulate securities trading } \\
\text { venues by their Statutes of Autonomy." The article further specifies that the regulation shall } \\
\text { govern the services provided, the procedures for setting and disclosing tariffs, the legal regime } \\
\text { of participating entities, the proceedings to ensure delivery, payment and collateral. It also } \\
\text { covers procedures regarding nonpayments, disposal of unpaid securities, and separation of } \\
\text { assets in the event of a declaration of bankruptcy. } \\
\text { In addition, Iberclear has to comply with the rules of conduct, established in Art. 79, } 1 \mathrm{~d} \text { ) of } \\
\text { LMV: it must "possess adequate organizational arrangements to perform its activity and } \\
\text { establish the suitable internal controls to ensure prudent management and prevent breaches of } \\
\text { the duties and obligations imposed on it by the securities market regulation." }\end{array}$ \\
\hline Assessment & Observed. \\
\hline \multicolumn{2}{|l|}{ Comments } \\
\hline 5.4 & $\begin{array}{l}\text { Where financial agencies have oversight responsibilities for self-regulatory organizations } \\
\text { (e.g., payment systems), the relationship between them should be publicly disclosed. }\end{array}$ \\
\hline Description & $\begin{array}{l}\text { The Bolsas y Mercados Españoles (BME) is licensed by the Council of Ministers to operate } \\
\text { stock exchanges in Spain. The BME is a member-owned exchange and comprises the Madrid, } \\
\text { Barcelona, Bilbao, and Valencia stock exchanges, MF Mercados Financieros, Iberclear, and } \\
\text { BME Consulting. All members are licensed by the CNMV. The BME has to comply with all } \\
\text { notices and directives issued by the CNMV. In addition, significant rules and regulations of the } \\
\text { BME have to be approved by the CNMV prior to adoption by the BME. } \\
\text { As explained in 5.3., Iberclear's regulations are approved by both the BE and the CNMV, but its } \\
\text { supervision, inspection, and sanctions are the responsibility of the CNMV. The supervisory } \\
\text { powers over Iberclear are disclosed in the CNMV Annual Report on Activities and on } \\
\text { Iberclear's website. The book-entry public debt market is under BE supervision (Art. 84.1.a). }\end{array}$ \\
\hline Assessment & Observed. \\
\hline Comments & \\
\hline
\end{tabular}




\begin{tabular}{|c|c|}
\hline & $\begin{array}{l}\text { supervisory process, they should be guided by the same good transparency practices } \\
\text { specified for financial agencies. }\end{array}$ \\
\hline \multirow[t]{2}{*}{ Description } & $\begin{array}{l}\text { Art. } 13 \text { of LMV entrusts the CNMV to "seek to ensure the transparency of the securities } \\
\text { markets, the correct formation of prices on these markets, and the protection of investors by } \\
\text { promoting disclosure of any information necessary in order to attain these ends." In fact, Art. } 12 \\
\text { of RD } 726 / 1989 \text { (Sociedades Rectoras } y \text { Finanza Colectiva) establishes that the governing } \\
\text { bodies should oversee the transparency of the correct price formation, the strict observance of } \\
\text { contract norms, etc." }\end{array}$ \\
\hline & $\begin{array}{l}\text { The legal and regulatory framework for transparency and governance of publicly traded } \\
\text { institutions has improved significantly in recent years. Following the recommendations of the } \\
\text { Aldama Commission in 2003, the Spanish authorities issued a number of laws and regulations. } \\
\text { Thus, the stock exchange has extensive transparency requirements on the listed companies. See } \\
\text { www.BME.es. }\end{array}$ \\
\hline Assessment & Observed. \\
\hline \multicolumn{2}{|l|}{ Comments } \\
\hline \multicolumn{2}{|r|}{ VI. Open Process for Formulating and Reporting of FinanCial Policies } \\
\hline 6.1 & $\begin{array}{l}\text { The conduct of policies by financial agencies should be transparent, compatible with } \\
\text { confidentiality considerations and the need to preserve the effectiveness of actions by } \\
\text { regulatory and oversight agencies. }\end{array}$ \\
\hline Description & $\begin{array}{l}\text { The regulatory framework governing the conduct of financial policies is explained in the LMV. } \\
\text { The law specifies the measures and actions to be taken by the CNMV. The CNMV reports each } \\
\text { year on its supervisory and regulatory activities in the CNMV Annual Report on Activities. In } \\
\text { addition, the functions and the internal regime of the CNMV with regard to supervision are } \\
\text { described on the CNMV website/ What we do. }\end{array}$ \\
\hline Assessment & Observed. \\
\hline \multicolumn{2}{|l|}{ Comments } \\
\hline 6.1 .1 & $\begin{array}{l}\text { The regulatory framework and operating procedures governing the conduct of financial policies } \\
\text { should be publicly disclosed and explained. }\end{array}$ \\
\hline \multirow[t]{4}{*}{ Description } & $\begin{array}{l}\text { The regulatory framework governing the conduct of financial policies is explained in the LMV. } \\
\text { The law specifies the measures and actions to be taken by the CNMV and is available on } \\
\text { CNMV's website. }\end{array}$ \\
\hline & $\begin{array}{l}\text { Art. } 15 \text { of LMV states that the CNMV may issue circulars to develop and enforce the norms } \\
\text { contained in Royal Decrees or Ministerial Orders (provided it is explicitly allowed to do so). } \\
\text { The circulars are published in the BOE. The legal framework is posted on the website. In } \\
\text { addition, the functions of the CNMV with regard to securities market supervision are described } \\
\text { on the CNVM website. The operating procedures are thoroughly explained in the Annual Report } \\
\text { on Activities, which includes the main legal changes and their importance for the securities } \\
\text { market. The Annual Report on Activities is available in hard copy as well as on the CNMV } \\
\text { website, in both Spanish and English. }\end{array}$ \\
\hline & $\begin{array}{l}\text { The CNMV has (by law) an Advisory Committee, which should issue reports preceding the } \\
\text { CNMV Circulars and other securities market regulation issued by the government or the ME, in } \\
\text { fulfillment of the public hearings required by law prior to approval of new legislation. This } \\
\text { Advisory Committee has about } 20 \text { members representing the securities markets, thus the parties } \\
\text { affected by the regulatory framework and operating procedures of the CNMV are well informed } \\
\text { and involved in the regulatory process. }\end{array}$ \\
\hline & $\begin{array}{l}\text { In addition to the information on the website, interviews by senior CNMV officers and press } \\
\text { releases, seminars, classes, etc., are organized to explain the conduct of policies. The CNMV }\end{array}$ \\
\hline
\end{tabular}




\begin{tabular}{|c|c|}
\hline & $\begin{array}{l}\text { also has an Investor Assistance Office, which the investors can contact for any complaint or } \\
\text { question. } \\
\text { Finally, the full text of the internal regulations of the CNMV, including its functions, can be } \\
\text { consulted in the legislation section of the CNMV website. Internal procedures for entities } \\
\text { operating in the securities market (five procedures); securities issuance (five procedures); and } \\
\text { administration and services (six procedures) are under development (since February 2004), and } \\
\text { can be published in the BOE if the president of the CNMV so decides. }\end{array}$ \\
\hline Assessment & Observed. \\
\hline Comments & $\begin{array}{l}\text { The internal procedures under development should be published in the } \mathrm{BOE} \text { and on the website } \\
\text { (compatible with confidentiality considerations and the need to preserve the effectiveness of the } \\
\text { CNMV) after they have been formally approved. }\end{array}$ \\
\hline 6.1 .2 & $\begin{array}{l}\text { The regulations for financial reporting by financial institutions to financial agencies should be } \\
\text { publicly disclosed. }\end{array}$ \\
\hline \multirow[t]{2}{*}{ Description } & $\begin{array}{l}\text { The regulations for financial reporting and other periodic information to the CNMV by the } \\
\text { supervised entities are posted on the website under "Legislation." }\end{array}$ \\
\hline & $\begin{array}{l}\text { The website also contains the models (Modelos Normalizados) followed by the supervised } \\
\text { entities to remit public periodic information to the CNMV. }\end{array}$ \\
\hline Assessment & Observed. \\
\hline \multicolumn{2}{|l|}{ Comments } \\
\hline 6.1 .3 & $\begin{array}{l}\text { The regulations for the operation of organized financial markets (including those for issuers of } \\
\text { traded financial instruments) should be publicly disclosed. }\end{array}$ \\
\hline Description & $\begin{array}{l}\text { The regulations for the operation of organized financial markets (laws, regulations, ministerial } \\
\text { orders, and CNMV circulars) are disclosed on CNMV's website under Legislación, } \\
\text { jurisprudencia y otras normas. All regulations are published in the BOE. In addition, they are } \\
\text { made public through the means mentioned in } 6.1 .1 \text {, website, Investor Assistance Office, } \\
\text { seminars, annual reports, pamphlets, etc. Reportedly, some market participants have expressed } \\
\text { the need to improve the quality of CNMV's service regarding questions on the interpretation of } \\
\text { certain regulations, e.g., new products. }\end{array}$ \\
\hline Assessment & Observed. \\
\hline Comments & $\begin{array}{l}\text { The regulation should be clear and if the CNMV interpretations on a certain rules are requested, } \\
\text { the CNMV as a regulator should provide advice on a timely basis. }\end{array}$ \\
\hline 6.1 .4 & $\begin{array}{l}\text { Where financial agencies charge fees to financial institutions, the structure of such fees should } \\
\text { be publicly disclosed. }\end{array}$ \\
\hline \multirow[t]{2}{*}{ Description } & $\begin{array}{l}\text { The regulation and procedures referring to payment of fees are posted on the website under } \\
\text { Legislación, Jurisprudencia y Otras Normas and What is the CNMV?/ Payment of fees. The } \\
\text { annual report includes a section on the fees and their contribution to CNMV profits. }\end{array}$ \\
\hline & $\begin{array}{l}\text { The administrative act through which physical or legal persons are informed that they are } \\
\text { subject to fees, includes details on such fees, their structure, and payment. }\end{array}$ \\
\hline Assessment & Observed. \\
\hline \multicolumn{2}{|l|}{ Comments } \\
\hline 6.1 .5 & $\begin{array}{l}\text { Where applicable, formal procedures for information sharing and consultation between financial } \\
\text { agencies (including central banks), domestic and international, should be publicly disclosed. }\end{array}$ \\
\hline Description & Art. 90 of the LMV states that "in performing the functions of surveillance and supervision \\
\hline
\end{tabular}




\begin{tabular}{|c|c|}
\hline & $\begin{array}{l}\text { envisaged in this and other laws, the National Securities Market Commission shall cooperate } \\
\text { with the competent authorities of foreign states and may sign memoranda of understanding for } \\
\text { this purpose. In particular, the Commission may provide information regarding the } \\
\text { management, administration, conduct of business, solvency, and ownership of investment } \\
\text { services firms and other registered firms, as well as information which enables better } \\
\text { supervision of the securities markets or serves to prevent, prosecute or sanction irregular } \\
\text { conduct. (...) When the information originates in another member state of the European } \\
\text { Economic Area, it may not be disclosed without the express consent of the competent } \\
\text { authorities which provided it and, in such cases, solely for the purposes for which consent was } \\
\text { given.” } \\
\text { To support its supervisory responsibilities, the CNMV has signed cooperation agreements with } \\
\text { the BE, the DGSFP, and the SEPLAC. The possibility to sign agreements between national } \\
\text { supervisors is recognized in the D.A. } 2 \text { of the Financial Law, which points to an obligation of } \\
\text { cooperation between the BE, the CNMV and the Ministry of Economy in order to harmonize } \\
\text { supervision practices and criteria and to interchange relevant information. There is also an } \\
\text { agreement with the BE in the field of prevention of money laundering and another on exchange } \\
\text { of statistical information. } \\
\text { In addition, the CNMV has signed contracts of consultation and technical assistance with } \\
\text { several Latin American countries. These MoUs, as well as MoUs with IOSCO, the Forum of } \\
\text { European Securities Commissions (FESCO) and the London International Financial Futures } \\
\text { Exchange (LIFFE) are made public in the Legislación, Jurisprudencia y Otras Normas section } \\
\text { of CNMV's website. However, the national agreements are not disclosed. }\end{array}$ \\
\hline Assessment & Broadly observed. \\
\hline Comments & $\begin{array}{l}\text { Existing treaties with national regulators should be made public. Knowledge of consultation } \\
\text { procedures between domestic agencies provides the public with assurances that financial } \\
\text { agencies have established mechanisms to deal with regulatory issues and problems that cut } \\
\text { across their mandates. }\end{array}$ \\
\hline 6.2 & $\begin{array}{l}\text { Significant changes in financial policies should be publicly announced and explained in a } \\
\text { timely manner. }\end{array}$ \\
\hline \multirow[t]{5}{*}{ Description } & $\begin{array}{l}\text { The CNMV publicly announces and explains significant changes in financial policies (including } \\
\text { legislation and circulars) through its Annual Report on Activities, the website, and press } \\
\text { releases. Major changes are published in the BOE the day following such decisions. The CNMV } \\
\text { has a Q\&A page on its website that replies to queries from the public. }\end{array}$ \\
\hline & $\begin{array}{l}\text { In addition, there is a section called "Documents under consultation" on the website, in which } \\
\text { all legislative projects regarding securities markets that are open to public consultation are } \\
\text { disclosed (both Spanish and international). The time limit for comments as well as the means to } \\
\text { submit comments are specified. }\end{array}$ \\
\hline & $\begin{array}{l}\text { Article } 13 \text { of LMV establishes that the CNMV President shall appear in Parliament to report on } \\
\text { the agency's activities and on the situation of the organized financial markets, including the } \\
\text { most significant legislative changes during the year. The statement is also published in the } \\
\text { Diario de Sesiones del Congreso. }\end{array}$ \\
\hline & $\begin{array}{l}\text { In addition, the LMV (Art. 23) establishes that the CNMV Advisory Committee "shall report on } \\
\text { draft general regulations on matters related to the securities markets that are referred to it by the } \\
\text { Government or by the Ministry of Economy and Finance, in fulfillment of the principle of } \\
\text { consultation of affected sectors during preparation of administrative provisions." This Advisory } \\
\text { Committee has about twenty members representing the securities market (appointment } \\
\text { procedures R.G. 504/2003), thus the parties affected by changes in financial policies are well } \\
\text { informed and involved in the regulatory process. }\end{array}$ \\
\hline & $\begin{array}{l}\text { The General Directorate of Treasury and Financial Policy (DGTPF) is responsible for sending } \\
\text { drafts of Royal Decrees and Ministerial Orders to the CNMV Advisory Committee. In addition, }\end{array}$ \\
\hline
\end{tabular}




\begin{tabular}{|c|c|}
\hline & $\begin{array}{l}\text { the DGTPF has the authority to give audience to the affected sectors as they esteem convenient. } \\
\text { In the same manner, the LMV states that draft CNMV circulars should be sent to the Advisory } \\
\text { Committee in fulfillment of the principle of consultation of affected sectors during preparation } \\
\text { of administrative provisions. }\end{array}$ \\
\hline Assessment & Observed. \\
\hline \multicolumn{2}{|l|}{ Comments } \\
\hline 6.3 & $\begin{array}{l}\text { Financial agencies should issue periodic public reports on how their overall policy } \\
\text { objectives are being pursued. }\end{array}$ \\
\hline Description & $\begin{array}{l}\text { Every year the CNMV issues an Annual Report on Activities and an Annual Report on the } \\
\text { Securities Markets. Both reports are issued in both Spanish and English and distributed to the } \\
\text { press, the markets, national and international supervisory authorities, official state institutions, } \\
\text { the CNMV Advisory Committee, and the universities. Both reports are posted on the website } \\
\text { section Reports and Publications. Access to the reports on the web is at no cost. Before } \\
\text { publication there is a public presentation by the CNMV president to market participants and the } \\
\text { press. The reports usually are approved in May of the following year and distributed at the } \\
\text { beginning of June. } \\
\text { The Annual Report on Activities describes the governing bodies and structure of the CNMV, the } \\
\text { activities in the securities markets, issuers' disclosure, takeover bids, authorizations and } \\
\text { registrations, supervision activities, and so on. } \\
\text { Every year the CNMV president appears before the Parliamentary Committee on Economics, } \\
\text { Trade and Finance (Comisión de Economí y Hacienda del Congreso de los Diputados) to } \\
\text { present those reports. This appearance is reported in the Diario de Sesiones del Congreso. } \\
\text { In addition, the CNMV publishes an Annual Report on Investor Complaints, available on the } \\
\text { website and in hard copy, including statistics and information on complaints procedures. }\end{array}$ \\
\hline Assessment & Observed. \\
\hline Comments & $\begin{array}{l}\text { Transparency would be enhanced further with disclosure of the speeches of the CNMV } \\
\text { President before Parliament. }\end{array}$ \\
\hline 6.4 & $\begin{array}{l}\text { For proposed substantive technical changes to the structure of financial regulations, there } \\
\text { should be a presumption in favor of public consultations, within an appropriate period. }\end{array}$ \\
\hline Description & $\begin{array}{l}\text { As described in 6.2., the LMV Art. } 23 \text { establishes that the CNMV Advisory Committee "shall } \\
\text { report on draft general regulations on matters related to the securities markets that are referred } \\
\text { to it by the Government or the Ministry of Economy and Finance, in fulfillment of the principle } \\
\text { of consultation of affected sectors during preparation of administrative provisions." Similarly, } \\
\text { the LMV states that CNMV Circulars should be sent to the Advisory Committee before } \\
\text { approval. As mentioned, the Advisory Committee has about twenty representatives from the } \\
\text { securities market (appointment procedures R.G. 504/2003) and thus the parties affected by } \\
\text { changes in financial policies are well informed and involved in the regulatory process. } \\
\text { In addition, the website, under Documents under consultation, posts all legislative projects on } \\
\text { the securities markets that are open to public consultation (both Spanish and international). The } \\
\text { timeline and procedure for submitting comments is specified. Market participants have } \\
\text { expressed appreciation with the authorities' efforts to involve the affected parties in the } \\
\text { regulatory process, even if the consultative period is sometimes considered too short. }\end{array}$ \\
\hline Assessment & Observed. \\
\hline Comments & \\
\hline & VII. Public Availability of Information on FinanCial Policies \\
\hline
\end{tabular}




\begin{tabular}{|c|c|}
\hline 7.1 & $\begin{array}{l}\text { Financial agencies should issue a periodic public report on the major developments of the } \\
\text { sector(s) of the financial system for which they carry designated responsibility. }\end{array}$ \\
\hline \multirow[t]{4}{*}{ Description } & $\begin{array}{l}\text { The LMV Art.13 establishes the obligation of the CNMV to prepare and publish an annual } \\
\text { report describing the general condition of the securities markets. This should also be presented } \\
\text { to the Parliamentary Committee on Economics, Trade, and Finance. The president of CNMV } \\
\text { shall also appear before the Committee to respond to questions on the report as often as the } \\
\text { Parliament may require. This report analyzes the primary and secondary securities markets in } \\
\text { Spain and the supervised entities. The report is made public in hard copy and on the website. }\end{array}$ \\
\hline & $\begin{array}{l}\text { The report is issued in both Spanish and English and distributed to the press, the markets, } \\
\text { national and international supervisory authorities, official state institutions, the CNMV } \\
\text { Advisory Committee, and the universities. The report is posted on the website section Reports } \\
\text { and Publications. Access to the report on the web is at no cost. Before the report is published } \\
\text { there is a public presentation by the CNMV President to market participants and the press. The } \\
\text { report usually is approved in May of the following year and distributed in early June. }\end{array}$ \\
\hline & $\begin{array}{l}\text { Every month the CNMV elaborates a short report on general developments in the money } \\
\text { markets. The CNMV also publishes a monthly bulletin, The CNMV Informs, where the CNMV } \\
\text { describes the movements in the CNMV registers: operations of the entities, issuance of } \\
\text { securities, and so on. In addition, there is daily information on the website in real time. }\end{array}$ \\
\hline & $\begin{array}{l}\text { Both the periodic and the ad hoc documents and statistics are publicly available on the website } \\
\text { section Publications and other documents. }\end{array}$ \\
\hline Assessment & Observed. \\
\hline Comments & $\begin{array}{l}\text { The website could include a calendar for publications in order to give the public knowledge of } \\
\text { when the different publications and statistics will be published. }\end{array}$ \\
\hline 7.2 & $\begin{array}{l}\text { Financial agencies should seek to ensure that, consistent with confidentiality requirements, } \\
\text { there is public reporting of aggregate data related to their jurisdictional responsibilities on } \\
\text { a timely and regular basis. }\end{array}$ \\
\hline \multirow[t]{4}{*}{ Description } & See 7.1 \\
\hline & $\begin{array}{l}\text { The Official Register of the CNMV collects all public, financial (audit reports, half year and } \\
\text { trimester information, annual reports) and other (significant participants, relevant facts, } \\
\text { pamphlets, fees, contract-types, etc.) information on issuers, investment firms, public } \\
\text { investment institutions, risk capital entities, etc.; it is available on the website. }\end{array}$ \\
\hline & $\begin{array}{l}\text { In addition, the CNMV publishes on the web page (Relevant Facts) the annual accounts } \\
\text { together with the audit reports of issuers. The CNMV also publishes statistical reports with } \\
\text { aggregated financial and economic information, as well as operations in the primary and } \\
\text { secondary capital markets. }\end{array}$ \\
\hline & $\begin{array}{l}\text { All information on the securities markets and the entities is made public in aggregated form, } \\
\text { consistent with confidentiality requirements. This is done in the monthly Bulletin, as well as in } \\
\text { the Annual Report. In addition, aggregated statistical information is published on the CNMV } \\
\text { website/Publications. The annual report also contains aggregated data for previous years in } \\
\text { order to facilitate comparisons. }\end{array}$ \\
\hline Assessment & Observed. \\
\hline Comments & $\begin{array}{l}\text { According to some market participants, quarterly aggregated data is already outdated by the } \\
\text { time it is published - generally six weeks after the reference period. }\end{array}$ \\
\hline 7.3 & $\begin{array}{l}\text { Where applicable, financial agencies should publicly disclose their balance sheets on a } \\
\text { preannounced schedule and, after a predetermined interval, publicly disclose information } \\
\text { on aggregate market transactions. }\end{array}$ \\
\hline
\end{tabular}




\begin{tabular}{|c|c|}
\hline \multirow[t]{4}{*}{ Description } & $\begin{array}{l}\text { The CNMV budget is published on the website of the Comptroller General of the State } \\
\text { Administration (Intervención General de la Administración del Estado). }\end{array}$ \\
\hline & $\begin{array}{l}\text { Art. } 13 \text { of LMV states that "each year, the National Securities Market Commission shall present } \\
\text { a report on its activities and on the situation in the organized financial markets to the } \\
\text { Parliamentary Committee on Economics, Trade, and Finance. The President of the National } \\
\text { Securities Market Commission shall appear before the aforementioned Parliamentary } \\
\text { Committee to respond to questions on the report as often as the Parliament may require." } \\
\text { Art. } 24 \text { of LMV states that "together with the financial statements for the year, the Board of the } \\
\text { National Securities Market Commission shall submit, for Government approval, a proposal for } \\
\text { the distribution of surplus (...)." }\end{array}$ \\
\hline & $\begin{array}{l}\text { The annual report, which includes the annual accounts and the audit report, is published in June } \\
\text { of the following year. The report includes information on the administration of CNMV, the } \\
\text { main sources of profit and loss, and human resources. The report is presented and disseminated } \\
\text { widely. Within a month of board approval of the annual accounts, it is published in the BOE. }\end{array}$ \\
\hline & The CNMV does not engage in market transactions. \\
\hline Assessment & Observed. \\
\hline \multicolumn{2}{|l|}{ Comments } \\
\hline 7.3 .1 & $\begin{array}{l}\text { Consistent with confidentiality and privacy of information on individual firms, aggregate } \\
\text { information on emergency financial support by financial agencies should be publicly disclosed } \\
\text { through an appropriate statement when such disclosure will not be disruptive to financial } \\
\text { stability. }\end{array}$ \\
\hline \multicolumn{2}{|l|}{ Description } \\
\hline Assessment & Not applicable. \\
\hline Comments & Emergency financial support is not given by the CNMV. \\
\hline 7.4 & Financial agencies should establish and maintain public information services. \\
\hline Description & $\begin{array}{l}\text { The CNMV has the following main organs with responsibilities on public information services: } \\
\text { The Direction of Studies and Statistics performs different information activities: } \\
\text { (i) elaboration, publication, promotion and distribution of the Annual Report on Activities, } \\
\text { the Annual Report on the Securities Markets, market studies, statistical information on the } \\
\text { entities and the markets, the weekly bulletin The CNMV Informs. etc.; (ii) organization of } \\
\text { public events such as seminars, conferences, and so on. } \\
\text { The Communications Cabinet carries out the dissemination of messages to the public, } \\
\text { press releases and relations with the press, arranging interviews with senior CNMV } \\
\text { officers, etc. } \\
\text { The General Secretariat maintains the Official Public Register, which can be consulted } \\
\text { on the website, at CNMV's offices (open daily on weekdays from 8:30 to 17:30), or by } \\
\text { mail and fax. It administers the Investor Complaints Service (see 7.7) and the CNMV } \\
\text { website. } \\
\text { The General Directorate of Markets and Investors is responsible for informing the public } \\
\text { about the securities markets and the participating entities, and as far as possible, educating } \\
\text { investors through classes. It also administers the Investors Corner section of the website } \\
\text { (see } 6.1 .1 \text { ), which contains (i) information (news items, consultation service, a description } \\
\text { of the available information on the website, and frequently asked questions); (ii) investor } \\
\text { orientation (on rights and responsibilities, financial products, intermediaries, markets, } \\
\text { information guides...); and (iii) warnings (investor defense, messages to public). It runs the } \\
\text { Investor Assistance Office, and is in charge of elaborating the Investor Guides with the } \\
\text { objective to disseminate to an non-specialized audience relevant material on financial }\end{array}$ \\
\hline
\end{tabular}




\begin{tabular}{|c|c|}
\hline & $\begin{array}{l}\text { instruments, intermediaries, and procedures and practices in the markets. Investors can } \\
\text { contact the Investor Assistance Office for any complaint or question, through mail, email, } \\
\text { telephone, or in person at the CNMV offices. } \\
\text { The CNMV publicly discloses and explains the regulatory framework and operating procedures } \\
\text { through the Advisory Committee. The committee issues reports on draft CNMV Circulars and } \\
\text { other capital market regulation issued by the Government or the Ministry of Economy and } \\
\text { Finance, in fulfillment of the obligation of public hearings, as required by law prior to approval } \\
\text { of new legislation (LMV Art. 23). In addition, all new legislation is published in the BOE. } \\
\text { The CNMV maintains a website (www.cnmv.es) that includes information on CNMV's } \\
\text { functions, securities markets legislation, relevant facts, the official register, press releases, } \\
\text { investors' corner, information on activities, and the publications of the CNMV. The website is } \\
\text { available in both Spanish and English. }\end{array}$ \\
\hline Assessment & Observed. \\
\hline \multicolumn{2}{|l|}{ Comments } \\
\hline 7.4 .1 & $\begin{array}{l}\text { Financial agencies should have a publications program, including a periodic public report on } \\
\text { their principal activities issued at least annually. }\end{array}$ \\
\hline Description & $\begin{array}{l}\text { As mentioned earlier, the CNMV issues an Annual Report on Activities (6.3) and an Annual } \\
\text { Report on the Securities Markets (7.1). Both reports are issued in both Spanish and English and } \\
\text { distributed to the press, the markets, national and international supervisory authorities, official } \\
\text { state institutions, the CNMV Advisory Committee, and the universities. Both reports are posted } \\
\text { on the website under Reports and Publications. Access to the reports on the web is at no cost. } \\
\text { Before the reports are published there is a public presentation by the CNMV President to market } \\
\text { participants and the press. The reports usually are approved in May of the following year and } \\
\text { distributed at the beginning of June. } \\
\text { Every month the CNMV elaborates a short report on the general development in the money } \\
\text { markets, and publishes a bulletin (The CNMV Informs) where it describes the movements in the } \\
\text { CNMV registers: operations of the entities, issuance of securities, etc. In addition, there is daily } \\
\text { information on the website in real time. } \\
\text { Both the periodic and the ad hoc documents and statistics are publicly available on the website } \\
\text { under Publications and other documents. In addition, the CNMV publishes the Annual Report } \\
\text { on Investors Complaints, available on the website and in hard copy, including complaints } \\
\text { statistics and information on the procedures. Starting in } 2005 \text { it is issued three times a year. }\end{array}$ \\
\hline Assessment & Observed. \\
\hline \multicolumn{2}{|l|}{ Comments } \\
\hline 7.4 .2 & $\begin{array}{l}\text { Senior financial agency officials should be ready to explain their institution's objective(s) and } \\
\text { performance to the public, and have a presumption in favor of releasing the text of their } \\
\text { statements to the public. }\end{array}$ \\
\hline Description & $\begin{array}{l}\text { Senior CNMV officers are ready to explain their institution's objectives and performance to the } \\
\text { public and do so through following channels: (i) public hearings before Parliamentary } \\
\text { committees (Art. } 13 \text { of LMV); (ii) formal or informal speeches in various fora; (iii) interviews } \\
\text { with the media (written press, radio and television, and press releases); (iv) articles issued in } \\
\text { business publications; and (v) publications like the annual reports. However, so far there has } \\
\text { been no presumption in favor of releasing the text of their statements on the website. }\end{array}$ \\
\hline Assessment & Broadly observed. \\
\hline Comments & $\begin{array}{l}\text { There should be a presumption in favor of releasing the text of public statements by senior } \\
\text { financial agency officials. The speeches could be posted on the website. }\end{array}$ \\
\hline
\end{tabular}




\begin{tabular}{|c|c|}
\hline 7.5 & $\begin{array}{l}\text { Texts of regulations and any other generally applicable directives and guidelines issued by } \\
\text { financial agencies should be readily available to the public. }\end{array}$ \\
\hline Description & $\begin{array}{l}\text { Texts of regulations and generally applicable directives and guidelines are available to the } \\
\text { public through official publications, the Annual Report, and the website under Legislación, } \\
\text { Jurisprudencia y Otras Normas. New legislation is also published in the BOE. In addition, } \\
\text { CNMV Circulars and Resolutions are posted on the website. The legislation of the European } \\
\text { community is on the website under Normativa Comunitaria. }\end{array}$ \\
\hline Assessment & Observed. \\
\hline \multicolumn{2}{|l|}{ Comments } \\
\hline 7.6 & $\begin{array}{l}\text { Where there are deposit insurance guarantees, policyholder guarantees, and any other } \\
\text { client asset protection schemes, information on the nature and form of such protections, } \\
\text { the operating procedures, how the guarantee is financed, and the performance of the } \\
\text { arrangement should be publicly disclosed. }\end{array}$ \\
\hline Description & $\begin{array}{l}\text { The Investor Protection Scheme (Fondo de Garantia de Inversiones, FGI) was created in } 2001 \\
\text { (R.G. 948/2001) and offers coverage up to a maximum of } € 20,000 \text { per investor. The Fund is } \\
\text { administrated by a management company supervised by the CNMV. This is disclosed in } \\
\text { CNMV's Annual Report in a dedicated section on the FGI, which includes information on } \\
\text { contributions and performance. } \\
\text { On CNMV's website under Investor Corner, there is a link to the FGI website, which describes } \\
\text { the scheme, contains the legislation, and indicates procedures for the execution of the guarantee. } \\
\text { Financial information is not disclosed on the website. }\end{array}$ \\
\hline Assessment & Observed. \\
\hline Comments & $\begin{array}{l}\text { The FGI website, which was set up in } 2003 \text {, could include more information on the nature and } \\
\text { form of the guarantee, including operating procedures, how the guarantee is financed, and the } \\
\text { performance of the arrangement. }\end{array}$ \\
\hline 7.7 & $\begin{array}{l}\text { Where financial agencies oversee consumer protection arrangements (such as dispute } \\
\text { settlement processes), information on such arrangements should be publicly disclosed. }\end{array}$ \\
\hline \multirow[t]{4}{*}{ Description } & $\begin{array}{l}\text { The CNMV Investor Complaints Service is the organ responsible for attending complaints from } \\
\text { the investors when they consider that the integrity of their investments has been damaged by the } \\
\text { conduct of entities or persons under the supervision of the CNMV. }\end{array}$ \\
\hline & $\begin{array}{l}\text { The section Investors Corner of the CNMV website, includes a section on Warnings that details } \\
\text { the rules and procedures for investor protection as well as complaints related to the securities } \\
\text { markets. The section on Reclamations to the CNMV of CNMV's website contains the steps to } \\
\text { follow to present a complaint to the CNMV, as well as the procedures that the CNMV follows } \\
\text { to attempt to resolve the conflict. }\end{array}$ \\
\hline & $\begin{array}{l}\text { The CNMV publishes a quarterly (until } 2005 \text { yearly) Report on Complaints, which reports an } \\
\text { analysis of complaints received, including statistics and their main subject. }\end{array}$ \\
\hline & $\begin{array}{l}\text { In the same way, the Annual Report on Activities includes a section on the complaints service } \\
\text { that contains statistics on the entities against which the reclamations are made, the type of } \\
\text { reclamations, and their outcome. }\end{array}$ \\
\hline Assessment & Observed. \\
\hline \multicolumn{2}{|l|}{ Comments } \\
\hline \multicolumn{2}{|r|}{ VIII. ACCOUnTABILITY AND ASSURANCES OF INTEgRITY BY FinANCIAL AgENCIES } \\
\hline 8.1 & Officials of financial agencies should be available to appear before a designated public \\
\hline
\end{tabular}




\begin{tabular}{|c|c|}
\hline & $\begin{array}{l}\text { authority to report on the conduct of financial policies, explain the policy objective(s) of } \\
\text { their institution, describe their performance in pursuing their objective(s), and, as } \\
\text { appropriate, exchange views on the state of the financial system. }\end{array}$ \\
\hline \multirow[t]{2}{*}{ Description } & $\begin{array}{l}\text { Art. } 13 \text { of LMV establishes that "each year, the National Securities Market Commission shall } \\
\text { present a report on its activities and on the situation of the organized financial markets to the } \\
\text { Parliamentary Committee on Economics, Trade, and Finance. The President of the National } \\
\text { Securities Market Commission shall appear before the aforementioned Parliamentary } \\
\text { Committee to respond to questions on the report as often as the Parliament may require." In } \\
\text { practice this occurs 2-3 times a year. }\end{array}$ \\
\hline & The appearances are made public in the Diario de Sesiones del Congreso. \\
\hline Assessment & Observed. \\
\hline \multicolumn{2}{|l|}{ Comments } \\
\hline 8.2 & $\begin{array}{l}\text { Where applicable, financial agencies should publicly disclose audited financial statements } \\
\text { of their operations on a preannounced schedule. }\end{array}$ \\
\hline \multirow[t]{2}{*}{ Description } & $\begin{array}{l}\text { As a public entity, the CNMV annually has to account to the National Audit Office. The } \\
\text { financial statements are audited by the Comptroller General of the State Administration } \\
\text { (IGAE). The IGAE report is done in April-May of the following year. The Annual Report on } \\
\text { Activities, which includes the annual accounts and the audit report, is published in June of the } \\
\text { following year. The report describes the main information on the administration of CNMV as } \\
\text { well as the sources of profit and loss and human resources. The report is presented and } \\
\text { disseminated widely. The CNMV president also appears before the Parliamentary Committee } \\
\text { on Economics, Trade, and Finance to account for the report. Within a month after their Board } \\
\text { approval, the annual accounts are published in the BOE. }\end{array}$ \\
\hline & $\begin{array}{l}\text { Art. } 24 \text { of LMV states that "together with the financial statements for the year, the Board of the } \\
\text { National Securities Market Commission shall submit, for approval by the Government, a } \\
\text { proposal for the distribution of surplus and an explanatory report (...)." }\end{array}$ \\
\hline Assessment & Observed. \\
\hline \multicolumn{2}{|l|}{ Comments } \\
\hline 8.2 .1 & $\begin{array}{l}\text { Financial statements, if any, should be audited by an independent auditor. Information on } \\
\text { accounting policies and any qualification to the statements should be an integral part of the } \\
\text { publicly disclosed financial statements. }\end{array}$ \\
\hline \multirow[t]{2}{*}{ Description } & $\begin{array}{l}\text { The CNMV follows the accounting policies established under Title V "Accounting in the } \\
\text { Public Sector" of the General Budget Law. This law and the General Public Accounting Plan, } \\
\text { which governs the accounting procedures of the CNMV, are published in the BOE. The annual } \\
\text { accounts information in the Annual Report of the CNMV incorporates the IGAE audit report } \\
\text { and any qualification to the statements. However the notes to the accounts are not included. }\end{array}$ \\
\hline & $\begin{array}{l}\text { Finally, the CNMV, in addition to internal control by the IGAE, is subject to external control } \\
\text { by the National Audit Office (Tribunal de Cuentas). The IGAE sends the annual accounts and } \\
\text { audit report to the National Audit Office within one month of issuance of the report. The } \\
\text { National Audit Office report on the annual accounts, including any qualification to the financial } \\
\text { statements, is published in the BOE. }\end{array}$ \\
\hline Assessment & Observed. \\
\hline Comments & It is recommended that the notes to the financial statements be included in the annual report. \\
\hline 8.2 .2 & $\begin{array}{l}\text { Internal governance procedures necessary to ensure the integrity of operations, including } \\
\text { internal audit arrangements, should be publicly disclosed. }\end{array}$ \\
\hline
\end{tabular}




\begin{tabular}{|c|c|}
\hline \multirow[t]{2}{*}{ Description } & $\begin{array}{l}\text { The internal regime of the CNMV is based on the Internal Regulation (RRI) approved by the } \\
\text { board in July } 2003 \text { and published in the BOE. It is also available on CNMV's website. The } \\
\text { Annual Report on Activities contains a detailed description of how the CNMV is organized and } \\
\text { the responsibilities of the various divisions (Governing bodies and the structure of CNMV). } \\
\text { This includes an extensive description of the internal audit and other internal governance } \\
\text { procedures. The Internal Control Body issues an annual "Oversight Report on Compliance by } \\
\text { CNMV's governing bodies to Procedural Standards" pursuant to D.A. } 2 \text { of the Financial Law } \\
\text { (Law 44/2002). This report is included in the Annual report of the CNMV. }\end{array}$ \\
\hline & $\begin{array}{l}\text { The Internal Control Department, whose functions are established in the RRI, reports to the } \\
\text { Executive Committee. Its activities are in accordance to the internal audit norms of the CNMV, } \\
\text { which were approved by the board in December } 2004 \text { and are in line with the Institute of } \\
\text { Internal Auditors' (IIA) International Standards for the Professional Practice of Internal Audit. }\end{array}$ \\
\hline Assessment & Observed. \\
\hline \multicolumn{2}{|l|}{ Comments } \\
\hline 8.3 & $\begin{array}{l}\text { Where applicable, information on the operating expenses and revenues of financial } \\
\text { agencies should be publicly disclosed annually. }\end{array}$ \\
\hline Description & $\begin{array}{l}\text { See 7.3, } 8.2 \text { and 8.2.1. } \\
\text { The annual accounts published in the Annual Report on Activities include balance sheet, income } \\
\text { statement, and audit report. The Annual Report section "Administration and Resources" } \\
\text { analyzes the composition and evolution of the principal incomes and expenditure items. }\end{array}$ \\
\hline Assessment & Observed. \\
\hline \multicolumn{2}{|l|}{ Comments } \\
\hline 8.4 & $\begin{array}{l}\text { Standards for the conduct of personal financial affairs of officials and staff of financial } \\
\text { agencies and rules to prevent exploitation of conflicts of interest, including any general } \\
\text { fiduciary obligation, should be publicly disclosed. }\end{array}$ \\
\hline Description & $\begin{array}{l}\text { In addition to the incompatibilities and secrecy rules established in the LMV, the RRI and the } \\
\text { General Code of Conduct (CGC) are applicable to the officials of the CNMV and cover the } \\
\text { norms relating to incompatibilities, secrecy, operations in the market, and conflicts of interest. } \\
\text { The RRI is published in the BOE and both are available on the website. } \\
\text { The CGC (2003) develops the principles further, especially those relating to conduct, privileged } \\
\text { information, prevision of conflicts of interest, and responsibilities of CNMV staff. In addition, } \\
\text { it covers most of the dispositions of Order APU/516/2005 on Good Governance, which applies } \\
\text { to senior officers of the CNMV. In addition, a section on "Code of Conduct for CNMV Staff } \\
\text { and Executives" is included in the Annual Report on Activities. }\end{array}$ \\
\hline Assessment & Observed. \\
\hline \multicolumn{2}{|l|}{ Comments } \\
\hline 8.4 .1 & $\begin{array}{l}\text { Information about legal protections for officials and staff of financial agencies in the conduct of } \\
\text { their official duties should be publicly disclosed. }\end{array}$ \\
\hline Description & $\begin{array}{l}\text { The RRI and the CGC are applicable to CNMV officials and include information on the } \\
\text { juridical support that the CNMV grants officers in case of legal actions against them for actions } \\
\text { taken in the conduct of their official duties. Both documents are available on the website. }\end{array}$ \\
\hline Assessment & Observed. \\
\hline Comments & \\
\hline
\end{tabular}


Table 5. Summary Observance of IMF’s MFP Transparency Code-Securities Market Supervision

\begin{tabular}{|c|c|c|}
\hline \multirow{2}{*}{$\begin{array}{l}\text { Assessment } \\
\text { Grade }\end{array}$} & \multicolumn{2}{|r|}{ Practices Grouped by Assessment Grade } \\
\hline & Count & List \\
\hline Observed & 33 & $\begin{array}{l}\text { 5.1; 5.1.1; 5.1.2; 5.1.3; 5.1.4; 5.2; 5.3; 5.3.1; 5.4; 5.5; 6.1; 6.1.1; 6.1.2; 6.1.3; } \\
6.1 .4 ; 6.2 ; 6.3 ; 6.4 ; 7.1 ; 7.2 ; 7.3 ; 7.4 ; 7.4 .1 ; 7.5 ; 7.6 ; 7.7 ; 8.1 ; 8.2 ; 8.2 .1 ; \\
\text { 8.2.2;8.3;8.4; 8.4.1 }\end{array}$ \\
\hline Broadly observed & 2 & $6.1 .5 ; 7.4 .2 ;$ \\
\hline Partly observed & & \\
\hline Non-observed & & \\
\hline Not applicable & 1 & 7.3 .1 \\
\hline
\end{tabular}

\section{Recommended Action Plan and Authorities' Response to the Assessment}

\section{Recommended action plan}

18. The CNMV already adheres to almost all the practices of the Transparency Code. To further refine transparency, the CNMV may consider releasing the text of the President's speeches to the public. In addition to the international treaties, it should also make public the existing MoUs with other national agencies. Knowledge of consultation procedures between domestic agencies provides the public with assurances that financial agencies have established mechanisms to deal with regulatory issues and financial problems that cut across their mandates.

19. The following recommendations are meant to further enhance what is already a highly transparent situation:

- (6.1.1) Publish the internal procedures currently under development in the BOE and on the website (compatible with confidentiality considerations and the need to preserve the effectiveness of (NMV), after they have been formally approved.

- (6.1.3) Provide timely interpretation of CNMV rules whenever requested.

- (6.3) Disclose to the public the text of CNMV speeches before the Parliamentary Committee on Economics, Trade, and Finance, e.g., through the website.

- (7.6) Promote more information disclosure by the FGI on the investor protection scheme, including its operating procedures, financing, and performance.

- $\quad$ (8.2.1) Include the notes to the financial statements in the published annual report. 
Table 6. Recommended Action Plan to Improve Observance of IMF's MFP Transparency Code Practices-Securities Market Supervision

\begin{tabular}{|l|l|}
\hline \multicolumn{1}{|c|}{ Reference Practice } & \multicolumn{1}{|c|}{ Recommended Action } \\
\hline $\begin{array}{l}\text { VI. Open Process for } \\
\text { Formulating and Reporting of } \\
\text { Financial Policies }\end{array}$ & \\
\hline $\begin{array}{l}\text { 6.1.5 Where applicable, formal } \\
\text { procedures for information sharing } \\
\text { and consultation between financial } \\
\text { agencies (including central banks), } \\
\text { domestic and international, should } \\
\text { be publicly disclosed. }\end{array}$ & Make public the existing MoUs with the other national regulators. \\
\hline $\begin{array}{l}\text { VII. Public Availability of } \\
\text { Information on Financial Policies }\end{array}$ & \\
\hline $\begin{array}{l}7.4 .2 \text { Senior financial agency } \\
\text { officials should be ready to explain } \\
\text { their institution's objective(s) and } \\
\text { performance to the public, and } \\
\text { have a presumption in favor of } \\
\text { releasing the text of their } \\
\text { statements to the public. }\end{array}$ & $\begin{array}{l}\text { There should be a presumption in favor of releasing the text of senior } \\
\text { offials' statements to the public. The speeches before parliament should }\end{array}$ \\
\hline
\end{tabular}

\section{Authorities' response to the assessment}

20. The authorities are in broad agreement with the assessment, and a number of measures have already been adopted in line with the recommended plan of action:

- (6.1.3) Documents providing interpretation of CNMV rules have been posted on the website (Criterios en el Ambito de la Autorización y Registro de los Fondos de Inversión and Criterios sobre la Aplicación de la Nueva Normativa de Mercados Primarios).

- (6.3) A new section of CNMV's website (comunicaciones) is being set up which will contain, among other things, the speeches and statements of CNMV's senior officials.

- (7.6) The already availabile information about FGI's the investor protection scheme (investor corner section of CNMV's website) will be widened.

21. The authorities are also considering options to publish the text of existing MOUs with other national authorities (6.1.5), CNMV's internal procedures (6.1.1), and the notes to the financial statements (8.2.1). 


\section{Deposit Insurance}

\section{A. Information and Methodology Used for Assessment}

22. An evaluation of the Deposit Guarantee Funds' (Fondos de Garantía de Depósitos, FGDs) observance of good transparency practices relating to financial policy was carried out as part of the joint Fund-Bank Financial Sector Assessment Program (FSAP). The assessment was conducted against the IMF Code of Good Practices on Transparency in Monetary and Financial Policies (MFP Transparency Code). It was undertaken during JuneJuly 2005 and was based on: (a) relevant laws; (b) information made available on the FGD website; (c) information available in the annual reports; (d) responses to a pre-FSAP questionnaire; (e) discussions with FDG officials; and (f) discussions with commercial banks and bankers' associations.

23. The Spanish authorities cooperated fully with the assessment and provided all the necessary clarifications and documents.

\section{B. Institutional and Market Structure}

24. The broad objectives and institutional framework for the FGDs are stated in the Royal Decrees 4/1980, 18/1982, and 2606/1996. The FGDs have the double purpose of insuring deposits and restructuring distressed financial institutions.

25. The Spanish deposit guarantee system comprises three funds - one for commercial banks (FGDEB), one for savings banks (FGDCA), and one for credit cooperatives (FGDCC). The funds guarantee up to $€ 20,000$ per depositor in line with EU directives.

26. The three funds have each their own legal identity. Each fund is governed and managed by a Management Committee comprising eight members appointed by the MEfour representing the $\mathrm{BE}$ (same representatives for each fund; currently the deputy governor, two director generals, and a secretary-general), and four representing the member banks. The Management Company for the Deposit Guarantee Funds was set up in June 2000 with the sole purpose of managing and administrating the funds' capital. The Management Company is governed by the provisions of the Law on Economic Interest Groups (Law 12/1991) and the Performance Contracts signed with each fund.

27. The FDG's website (www.fgd.es) contains general information, legislation, entities, legal advice, press statements regarding activities in problem institutions and the annual reports. The website is available in both English and Spanish. Annual reports are issued for each of the three funds and for the Management Company. In addition to the financial statements, the annual reports contain a description of the funds' activities, including bank restructuring. The annual accounts have ample information for interested parties, including detailed data. 


\section{Practice-by-Practice Assessment}

28. The detailed assessment recognizes that deposit insurance and the legal and institutional framework differ from one country to another, as do the domestic circumstances. The assessment of observance with each practice of the MFP Transparency Code is based on existing laws, regulations, and practices. A five-part assessment system is used: Observed; broadly observed; partly observed; not observed; and not applicable: observed, implying full observance or with insignificant shortcomings; broadly observed, where minor weaknesses exist and these are not seen as being of a significant nature so as to raise serious doubts about the authority's ability to achieve the objective of that practice; partly observed, where shortcomings are sufficient to raise doubts about the authority's ability to achieve observance and which could affect the operational process and effectiveness of financial policies; not observed, where the practice is not being observed and no substantive progress has been recorded toward achieving the objectives of the practice; and not applicable, where, due to the country circumstances and the institutional and legal framework, the transparency practice is not applicable.

Table 7. Observance of IMF's MFP Transparency Code—Deposit Insurance Funds

\section{Clarity OF Roles, RESPONSIBILITIES, AND ObJeCtIVES OF FinANCIAL AGENCIES RESPONSIBLE FOR} FinanCial Policies

5.1

The broad objective(s) and institutional framework of financial agencies should be clearly defined, preferably in relevant legislation or regulation.

Description

The Spanish deposit guarantee system comprises three Deposit Guarantee Funds (FGDs) - the Deposit Guarantee Fund for Commercial Banks (FGDEB), the Deposit Guarantee Fund for Savings Banks (FGDCA), and the Deposit Guarantee Fund in Credit Cooperatives (FGDCC). The funds guarantee up to $€ 20,000$ per depositor, in line with EU requirements.

The objectives and institutional framework of the FGDs are stated in Royal Decrees 4/1980 of March 28, 1980; 18/1982 of September 24, 1982; and 2606/1996 of December 20, 1996. The latest decree implements European Parliament and Council of Europe Directive 94/19/CE on deposit guarantee systems, already partially implemented by Royal Decree 12/1995 on Urgent Budgetary, Taxation, and Financial Measures, which introduced obligatory membership to the funds, conditions for exemption, and grounds for exclusion. Royal Decree 2606/1996 completes the transposition of Directive 94/19/CE into Spanish law. In particular, it brings under a single text the regulations governing the different funds.

Royal Decree 2606/1996 (Art. 1) states that the FGDs shall have legal personality and capacity to carry out of their functions under private law.

Each fund has its own legal identity. It is governed and managed by a Management Committee compromising eight members appointed by the Ministry of Economy and Finance. Four of these members represent the BE (same for each fund) and four represent the member banks of each FGD. The Management Company for the Deposit Guarantee Funds (Sociedad Gestora de los Fondos de Garantía de Depósitos en Entidades de Crédito, Agrupación de Interés

Económico) was set up in June 2000 with the purpose of managing the funds' capital. The Management Company is governed by the provisions of Law 12/1991 on Economic Interest Groups and the Performance Contracts signed with each fund.

Relevant legislation is posted on the website (both in English and Spanish). 


\begin{tabular}{|c|c|}
\hline \multicolumn{2}{|l|}{ Comments } \\
\hline 5.1 .1 & The broad objective(s) of financial agencies should be publicly disclosed and explained. \\
\hline \multirow[t]{3}{*}{ Description } & $\begin{array}{l}\text { The Spanish FGDs have traditionally had the double mandate of insuring deposits and } \\
\text { restructuring problem banks. The current regulations have maintained both functions. } \\
\text { Information on the objectives of the funds is available on the website (www.fgd.es). }\end{array}$ \\
\hline & $\begin{array}{l}\text { The law requires that information on the FGDs be disseminated by member banks. Art. } 5.4 \text { of } \\
\text { R.D. } 2606 / 1996 \text { states that "institutions that are members of the Funds (...) shall also make } \\
\text { information concerning the characteristics of the Fund available to the public at their offices, and } \\
\text { shall indicate, where applicable, the coverage provided by foreign schemes or the Funds. In } \\
\text { particular, they shall specify in detail the regime under which securities are deposited or registered } \\
\text { with other financial institutions." }\end{array}$ \\
\hline & $\begin{array}{l}\text { In addition, the Bank of Spain has some information on the FGDs on the new section of the } \\
\text { website Portal del Cliente Bancario (in Spanish only). }\end{array}$ \\
\hline Assessment & Observed. \\
\hline \multicolumn{2}{|l|}{ Comments } \\
\hline 5.1 .2 & $\begin{array}{l}\text { The responsibilities of the financial agencies and the authority to conduct financial policies } \\
\text { should be publicly disclosed. }\end{array}$ \\
\hline Description & $\begin{array}{l}\text { The Funds don't have faculty to set financial policies. Royal Decree } 2606 / 1996 \text { establishes their } \\
\text { responsibilities in the fulfillment their double mandate of insuring deposits (Art. 9, payments) } \\
\text { and restructuring problem banks (Art. 10, other actions of the FGD). Such responsibilities are } \\
\text { entrusted to each Management Committee. }\end{array}$ \\
\hline Assessment & Observed. \\
\hline \multicolumn{2}{|l|}{ Comments } \\
\hline 5.1 .3 & $\begin{array}{l}\text { Where applicable, the broad modalities of accountability for financial agencies should be } \\
\text { publicly disclosed. }\end{array}$ \\
\hline Description & $\begin{array}{l}\text { Article } 2 \text { states that "each Management Committee shall have, in addition to the functions } \\
\text { mentioned elsewhere in RD.2606/1994, the following duties and functions: } \\
\text { - To inform and advise the BE on matters under the competency of the Funds; } \\
\text { - To approve the accounts that the Funds must provide to members and the BE each year." } \\
\text { Annual reports are issued for each Funds and for the Management Company. In addition to the } \\
\text { financial statements, the annual reports contain a description of the Funds' activities, including } \\
\text { bank restructuring. Relevant legislation, as well as the annual reports, are posted on the website. }\end{array}$ \\
\hline Assessment & Observed. \\
\hline \multicolumn{2}{|l|}{ Comments } \\
\hline 5.1 .4 & $\begin{array}{l}\text { Where applicable, the procedures for appointment, terms of office, and any general criteria for } \\
\text { removal of the heads and members of the governing bodies of financial agencies should be } \\
\text { publicly disclosed. }\end{array}$ \\
\hline \multirow[t]{2}{*}{ Description } & $\begin{array}{l}\text { RD 2606/1994 describes in Art. } 2 \text { the governing body, appointment procedures, terms of office, } \\
\text { requirements, and general criteria for removal of governing body members. }\end{array}$ \\
\hline & $\begin{array}{l}\text { Each FGD is governed and managed by a Management Committee compromising eight } \\
\text { members appointed by the ME-four representing the BE and four representing each FGD } \\
\text { member bank. "The representatives of the Bank of Spain shall be proposed forward by its } \\
\text { Executive Committee. The Deputy Governor of the Bank of Spain shall be a member of the } \\
\text { Management Committee and shall be chairman of each of the Funds. The representatives of the }\end{array}$ \\
\hline
\end{tabular}




\begin{tabular}{|c|c|}
\hline & $\begin{array}{l}\text { institutions shall be proposed by the associations representing commercial banks, savings banks, } \\
\text { and credit cooperatives (...). The persons appointed shall be of acknowledged commercial and } \\
\text { professional integrity and must possess adequate knowledge and experience for the exercise of } \\
\text { their functions." } \\
\text { The duration of the term in office of the members of the Management Committees is four years, } \\
\text { renewable except in the case of the chairman, whose terms is as long as that of the BE Deputy } \\
\text { Governor that fulfills the duty. } \\
\text { "The office of the representatives of credit institutions that are members of the Fund shall be } \\
\text { terminated under any of the following circumstances: } \\
\text { - Expiry of the term of the mandate. } \\
\text { - Resignation accepted by the Minister of the Economy. } \\
\text { Dismissal agreed by the Minister of the Economy for grave non-fulfillment of duties, } \\
\text { permanent inability to carry out the functions associated with the office, or following a } \\
\text { sentence for an offence involving deceit." } \\
\text { The legislation is posted on the website. The composition of the Management Committee is } \\
\text { made public in the Annual Report and on the website. }\end{array}$ \\
\hline Assessment & Observed. \\
\hline \multicolumn{2}{|l|}{ Comments } \\
\hline 5.2 & The relationship between financial agencies should be publicly disclosed. \\
\hline Description & $\begin{array}{l}\text { The relationship between the Funds and the BE is regulated and publicly disclosed in } \\
\text { RD 2606/1996. As described in 5.1.4, four members of the Management Committee represent the } \\
\text { BE, the BE Deputy Governor being the chairman of each Fund. The Funds are accountable to the } \\
\text { BE and may under exceptional circumstances draw on funds from the BE. } \\
\text { In addition, Art. } 2 \text { specifies the modalities of information exchange: "The Management } \\
\text { Committees shall demand from the Bank of Spain as much information they need regarding their } \\
\text { member institutions for the performance of their functions. In particular, they shall be informed by } \\
\text { the Bank of Spain regarding those institutions in economic difficulties that may require action on } \\
\text { the part of their respective Fund." } \\
\text { Article } 10.1 \text { states that "exceptionally, when according to the information supplied by the Bank of } \\
\text { Spain, the situation of a credit institution is such that it may be foreseen that the Fund shall be } \\
\text { obliged to make a payment (...), the Fund shall be able to carry out preventive measures and } \\
\text { restructuring of the institution concerned with a view to improving its viability and enabling it to } \\
\text { overcome its crisis, within the framework of an action plan proposed by the institution and } \\
\text { approved by the Bank of Spain." } \\
\text { Relevant legislation is posted on the website. }\end{array}$ \\
\hline Assessment & Observed. \\
\hline \multicolumn{2}{|l|}{ Comments } \\
\hline 5.3 & $\begin{array}{l}\text { The role of oversight agencies with regard to payment systems should be publicly } \\
\text { disclosed. }\end{array}$ \\
\hline \multicolumn{2}{|l|}{ Description } \\
\hline Assessment & Not applicable. \\
\hline Comments & The oversight of payment systems is the responsibility of the Bank of Spain. \\
\hline 5.3 .1 & $\begin{array}{l}\text { The agencies overseeing payment systems should promote the timely public disclosure of } \\
\text { general policy principles (including risk management policies) that affect the robustness of }\end{array}$ \\
\hline
\end{tabular}


systemically important payment systems.

\begin{tabular}{|l|l|}
\hline \multicolumn{2}{|l|}{ systemically important payment systems. } \\
\hline Description & \\
\hline Assessment & Not applicable. \\
\hline Comments & The oversight of payment systems is the responsibility of the Bank of Spain. \\
\hline $\mathbf{5 . 4}$ & $\begin{array}{l}\text { Where financial agencies have oversight responsibilities for self-regulatory organizations } \\
\text { (e.g., payment systems), the relationship between them should be publicly disclosed. }\end{array}$ \\
\hline Description & \\
\hline Assessment & Not applicable. \\
\hline Comments & \\
\hline 5.5 & $\begin{array}{l}\text { Where self-regulatory organizations are authorized to perform part of the regulatory and } \\
\text { supervisory process, they should be guided by the same good transparency practices } \\
\text { specified for financial agencies. }\end{array}$ \\
\hline Description & \multicolumn{2}{|l|}{} \\
\hline Assessment & Not applicable \\
\hline Comments & \\
\hline
\end{tabular}

\section{Open Process for Formulating and Reporting of FinanCial Policies}

\begin{tabular}{|l|l|}
\hline 6.1 & $\begin{array}{l}\text { The conduct of policies by financial agencies should be transparent, compatible with } \\
\text { confidentiality considerations and the need to preserve the effectiveness of actions by } \\
\text { regulatory and oversight agencies. }\end{array}$ \\
\hline Description & $\begin{array}{l}\text { The conduct of policies by the Funds, including actions to be taken in the event of bank problems, } \\
\text { are defined in RD 2606/1996 and made public. } \\
\text { The actions regarding individual institutions are made public by the supervisors after their } \\
\text { approval of the action plan. In addition, the actions taken by the FGD and payments made are } \\
\text { made public in the annual reports of the funds as well as in the annual report of the Management } \\
\text { Company. The annual reports are available on the website. }\end{array}$ \\
\hline Assessment & Observed. \\
\hline Comments & \\
\hline 6.1 .1 & $\begin{array}{l}\text { The regulatory framework and operating procedures governing the conduct of financial policies } \\
\text { should be publicly disclosed and explained. }\end{array}$ \\
\hline Description & $\begin{array}{l}\text { The regulatory framework and operating procedures governing the conduct of financial policies } \\
\text { are specified in the RD 2606/1996. The legislation is described and explained on the website } \\
\text { under General Information-Summary of Regulations. }\end{array}$ \\
\hline Assessment & Observed. \\
\hline Comments & \\
\hline 6.1 .2 & $\begin{array}{l}\text { The regulations for financial reporting by financial institutions to financial agencies should be } \\
\text { publicly disclosed. }\end{array}$ \\
\hline Description & \\
\hline Assessment & Not applicable. \\
\hline Comments & The supervisor makes public all regulations regarding financial institutions' reporting related to \\
\hline
\end{tabular}




\begin{tabular}{|c|c|}
\hline & the deposit guarantee (Circular 4/2004 of September 24, 2004; published in BOE, October 9. \\
\hline 6.1 .3 & $\begin{array}{l}\text { The regulations for the operation of organized financial markets (including those for issuers of } \\
\text { traded financial instruments) should be publicly disclosed. }\end{array}$ \\
\hline \multicolumn{2}{|l|}{ Description } \\
\hline Assessment & Not applicable. \\
\hline Comments & $\begin{array}{l}\text { The regulations for the operation of organized financial markets (including those for issuers of } \\
\text { traded financial instruments) are publicly disclosed by the CNMV. }\end{array}$ \\
\hline 6.1 .4 & $\begin{array}{l}\text { Where financial agencies charge fees to financial institutions, the structure of such fees should } \\
\text { be publicly disclosed. }\end{array}$ \\
\hline Description & $\begin{array}{l}\text { RD 2606/1996 Art. } 3 \text { states that "annual contributions by member institutions of the Funds shall } \\
\text { be } 2 \text { per } 1,000 \text { of the deposits held as at the end of the financial year for which the guarantee is } \\
\text { given. To this end, the basis for the calculation will be integrated with the deposits covered by } \\
\text { the system in accordance with the definition in Article 4.1, plus } 5 \text { per } 100 \text { of the quoted value of } \\
\text { the stock covered by the system, as defined in Article } 4.2 \text {, on the last day of trading of the year } \\
\text { in the relevant secondary market. When the assets of a Fund reach a sufficient amount for it to be } \\
\text { able to fulfill its functions, the Minister of Economy, upon proposal of the Bank of Spain, may } \\
\text { agree to a decrease in the contributions mentioned in point } 1 \text { of this article. In any case, such } \\
\text { contributions shall be suspended when the assets not committed to any of the operations proper to } \\
\text { the purposes of the Fund are equal to or greater than } 1 \text { per cent on the base of calculation of } \\
\text { contributions foreseen at the precedent section } 1 \text {, this fact being communicated by the } \\
\text { Management Committee in the form determined by it." This is also made public on the website } \\
\text { under General Information-Summary of the Regulations. }\end{array}$ \\
\hline Assessment & Observed. \\
\hline \multicolumn{2}{|l|}{ Comments } \\
\hline 6.1 .5 & $\begin{array}{l}\text { Where applicable, formal procedures for information sharing and consultation between } \\
\text { financial agencies (including central banks), domestic and international, should be publicly } \\
\text { disclosed. }\end{array}$ \\
\hline \multirow[t]{2}{*}{ Description } & $\begin{array}{l}\text { According to RD 2606/1996 Art.2 "the Management Committees shall demand from the Bank of } \\
\text { Spain as much information as needed regarding their member institutions for the performance of } \\
\text { their functions. In particular, they shall be informed by the Bank of Spain regarding those } \\
\text { institutions in economic difficulties that may require action on the part of their respective Fund." }\end{array}$ \\
\hline & $\begin{array}{l}\text { The Funds are members of the European Forum of Deposit Insurers (EFDI), which aims at } \\
\text { promoting European cooperation in the field of deposit insurance and to facilitate exchange of } \\
\text { expertise and information on issues of mutual interest and concern (www.efdi.net). }\end{array}$ \\
\hline Assessment & Observed. \\
\hline \multicolumn{2}{|l|}{ Comments } \\
\hline 6.2 & $\begin{array}{l}\text { Significant changes in financial policies should be publicly announced and explained in a } \\
\text { timely manner. }\end{array}$ \\
\hline Description & $\begin{array}{l}\text { Financial policies are not set by the FDG, but by the supervisors. However, the system for the } \\
\text { protection of deposits and claims on securities is well explained and disclosed in the relevant } \\
\text { laws and regulations and on the FGD website. Changes in these laws and regulations are subject } \\
\text { to public consultation procedures and are published in the BOE. }\end{array}$ \\
\hline Assessment & Observed. \\
\hline Comments & \\
\hline
\end{tabular}




\begin{tabular}{|c|c|}
\hline 6.3 & $\begin{array}{l}\text { Financial agencies should issue periodic public reports on how their overall policy } \\
\text { objectives are being pursued. }\end{array}$ \\
\hline Description & $\begin{array}{l}\text { Annual reports are issued for each Fund and for the Management Company. The annual reports } \\
\text { contain information on how the objectives are being pursued, and are available on the website } \\
\text { at no cost. Information of general interest, e.g., regarding problem institutions, is also available } \\
\text { on the website. The annual reports are sent to member banks, universities, and public entities in } \\
\text { the financial sector. }\end{array}$ \\
\hline Assessment & Observed. \\
\hline \multicolumn{2}{|l|}{ Comments } \\
\hline 6.4 & $\begin{array}{l}\text { For proposed substantive technical changes to the structure of financial regulations, there } \\
\text { should be a presumption in favor of public consultations, within an appropriate period. }\end{array}$ \\
\hline \multicolumn{2}{|l|}{ Description } \\
\hline Assessment & Not applicable. \\
\hline Comments & The FGD does not set financial policies. Public consultations are held by the regulators. \\
\hline \multicolumn{2}{|r|}{ ViI. Public Availability of Information on Financial Policies } \\
\hline 7.1 & $\begin{array}{l}\text { Financial agencies should issue a periodic public report on the major developments of the } \\
\text { sector(s) of the financial system for which they carry designated responsibility. }\end{array}$ \\
\hline Description & $\begin{array}{l}\text { The distribution of tasks and responsibilities between the FGD and the BE is such that the } \\
\text { mandate of the FGD does not include following developments in the sectors relevant to its } \\
\text { activities. The BE follows such developments and publishes periodic reports on the subject. } \\
\text { Relevant news are reported on the website and the annual reports. See } 6.3 \text {. }\end{array}$ \\
\hline Assessment & Not applicable. \\
\hline \multicolumn{2}{|l|}{ Comments } \\
\hline 7.2 & $\begin{array}{l}\text { Financial agencies should seek to ensure that, consistent with confidentiality } \\
\text { requirements, there is public reporting of aggregate data related to their jurisdictional } \\
\text { responsibilities on a timely and regular basis. }\end{array}$ \\
\hline Description & $\begin{array}{l}\text { The FGD discloses aggregate data on areas related to its jurisdictional responsibilities. In } \\
\text { particular, it publicly discloses data on its financial operations, i.e., collected contributions, } \\
\text { other funding, investments, pay-offs. } \\
\text { The BE publishes aggregate data on the banking sector. }\end{array}$ \\
\hline Assessment & Observed. \\
\hline \multicolumn{2}{|l|}{ Comments } \\
\hline 7.3 & $\begin{array}{l}\text { Where applicable, financial agencies should publicly disclose their balance sheets on a } \\
\text { preannounced schedule and, after a predetermined interval, publicly disclose information } \\
\text { on aggregate market transactions. }\end{array}$ \\
\hline Description & $\begin{array}{l}\text { According to the RD } 2606 / 1996 \text { Art.2.4, the Funds must provide annual accounts to their } \\
\text { members and the BE. The annual reports are also made public on the website. } \\
\text { Annually, the financial statements, audited by independent auditors and approved by the } \\
\text { Management Committee, are made public. In addition to the financial statements, the annual } \\
\text { report contains a description of the Funds' activities, including bank restructuring, as well as } \\
\text { aggregated data. Complementary information on signed contracts is remitted annually to the } \\
\text { National Audit Office (Tribunal de Cuentas). }\end{array}$ \\
\hline
\end{tabular}




\begin{tabular}{|c|c|}
\hline Assessment & Observed. \\
\hline \multicolumn{2}{|l|}{ Comments } \\
\hline 7.3 .1 & $\begin{array}{l}\text { Consistent with confidentiality and privacy of information on individual firms, aggregate } \\
\text { information on emergency financial support by financial agencies should be publicly disclosed } \\
\text { through an appropriate statement when such disclosure will not be disruptive to financial } \\
\text { stability. }\end{array}$ \\
\hline Description & $\begin{array}{l}\text { Emergency financial support information is publicly disclosed through a statement and on the } \\
\text { website. Nevertheless, this financial support needs to be previously authorized by the BE } \\
\text { through an action plan, as prescribed in the RD } 2606 / 1996 \text {. }\end{array}$ \\
\hline Assessment & Observed. \\
\hline \multicolumn{2}{|l|}{ Comments } \\
\hline 7.4 & Financial agencies should establish and maintain public information services. \\
\hline Description & $\begin{array}{l}\text { The FDG website contains general information, legislation, entities, legal advice, press } \\
\text { statements regarding activities in problem institutions, and the annual reports. The website is } \\
\text { available in both English and Spanish. The office responds via e-mail, fax, or telephone to } \\
\text { enquiries by the general public related to the mandate of the FGD. Contact information is } \\
\text { posted on the website. }\end{array}$ \\
\hline Assessment & Observed. \\
\hline \multicolumn{2}{|l|}{ Comments } \\
\hline 7.4.1 & $\begin{array}{l}\text { Financial agencies should have a publications program, including a periodic public report on } \\
\text { their principal activities issued at least annually. }\end{array}$ \\
\hline Description & $\begin{array}{l}\text { Annual reports are issued for each Fund and for the Management Company. In addition to the } \\
\text { financial statements, the annual reports contain a description of bank restructuring activities. } \\
\text { The annual accounts have ample information for interested parties, including detailed data. The } \\
\text { reports are available on the website. }\end{array}$ \\
\hline Assessment & Observed. \\
\hline \multicolumn{2}{|l|}{ Comments } \\
\hline 7.4 .2 & $\begin{array}{l}\text { Senior financial agency officials should be ready to explain their institution's objective(s) and } \\
\text { performance to the public, and have a presumption in favor of releasing the text of their } \\
\text { statements to the public. }\end{array}$ \\
\hline Description & $\begin{array}{l}\text { Senior officials of the FGD have the authority to explain their policies, objectives, and } \\
\text { performance to the public. This has not occurred in practice, however, other than through the } \\
\text { website, because no perceived need for doing so has arisen. In general, pursuant to Art.9 of } \\
\text { Directive } 94 / 19 \text {, credit institutions have responsibility for informing the depositors of the } \\
\text { deposit insurance guarantee. When there are problems in an institution, it is the BE that takes } \\
\text { decisions on the action plan. Hence, the BE and the problem institution, not the FGD, make } \\
\text { public statements. There have been no public statements of senior FGD officials. }\end{array}$ \\
\hline Assessment & Partly observed. \\
\hline Comments & $\begin{array}{l}\text { A more proactive approach to informing the public and a formal policy on public } \\
\text { communications by senior FGD officials and on the release of the texts of public statements } \\
\text { would be desirable. }\end{array}$ \\
\hline
\end{tabular}




\begin{tabular}{|c|c|}
\hline 7.5 & $\begin{array}{l}\text { Texts of regulations and any other generally applicable directives and guidelines issued by } \\
\text { financial agencies should be readily available to the public. }\end{array}$ \\
\hline Description & $\begin{array}{l}\text { The FGD does not have regulatory powers. However, the relevant legislation is made public in } \\
\text { the BOE and on FGD's website in both Spanish and English. A list of the relevant legislation is } \\
\text { also included in the annual reports. }\end{array}$ \\
\hline Assessment & Observed. \\
\hline \multicolumn{2}{|l|}{ Comments } \\
\hline 7.6 & $\begin{array}{l}\text { Where there are deposit insurance guarantees, policyholder guarantees, and any other } \\
\text { client asset protection schemes, information on the nature and form of such protections, } \\
\text { the operating procedures, how the guarantee is financed, and the performance of the } \\
\text { arrangement should be publicly disclosed. }\end{array}$ \\
\hline Description & $\begin{array}{l}\text { Relevant legislation and extensive explanations are available on the website and in the annual } \\
\text { reports. Annually, the financial statements, audited by independent auditors and approved by } \\
\text { the Management Committee, are made public. In addition to the financial statements, the annual } \\
\text { report contains a description of the Funds' activities, including bank restructuring, and data on } \\
\text { developments and pay-offs. The annual reports are posted on the website and sent to members } \\
\text { banks, official organizations, and the public upon request. }\end{array}$ \\
\hline Assessment & Observed. \\
\hline \multicolumn{2}{|l|}{ Comments } \\
\hline 7.7 & $\begin{array}{l}\text { Where financial agencies oversee consumer protection arrangements (such as dispute } \\
\text { settlement processes), information on such arrangements should be publicly disclosed. }\end{array}$ \\
\hline \multicolumn{2}{|l|}{ Description } \\
\hline Assessment & Not applicable. \\
\hline Comments & The FGD does not oversee any consumer protection arrangement. \\
\hline \multicolumn{2}{|r|}{ VIII. ACCOUNTABILITY AND ASSURANCES OF INTEgRITY by FINANCIAL AGENCIES } \\
\hline 8.1 & $\begin{array}{l}\text { Officials of financial agencies should be available to appear before a designated public } \\
\text { authority to report on the conduct of financial policies, explain the policy objective(s) of } \\
\text { their institution, describe their performance in pursuing their objective(s), and, as } \\
\text { appropriate, exchange views on the state of the financial system. }\end{array}$ \\
\hline Description & $\begin{array}{l}\text { FGD officials are not explicitly required to appear before designated authorities to report on } \\
\text { FGD's activities, objectives, and performance, or to exchange views on the state of the financial } \\
\text { system. So far, no occasions have arisen that created a perceived need for doing so, primarily } \\
\text { because the FGD has little room for discretion in its objectives and policies, except when it is } \\
\text { asked by the BE to intervene in a bank. The BE discloses information on the state of the } \\
\text { financial system and is by law required to appear before parliament to report on the issues. } \\
\text { When the issues refer to the FGD, the BE Governor relies on information and assistance } \\
\text { provided by the FGD. }\end{array}$ \\
\hline Assessment & Partly observed. \\
\hline Comments & $\begin{array}{l}\text { A stated policy and/or track record regarding the appearance of FGD officials before a } \\
\text { designated public authority, presumably parliament or a parliamentary commission, is needed } \\
\text { for an "observed" rating. Such an arrangement would be especially relevant in case of a bank } \\
\text { intervention by the FGD or in case of differences of opinion between the FGD and the BE on } \\
\text { bank restructuring issues. }\end{array}$ \\
\hline
\end{tabular}




\begin{tabular}{|c|c|}
\hline 8.2 & $\begin{array}{l}\text { Where applicable, financial agencies should publicly disclose audited financial statements } \\
\text { of their operations on a preannounced schedule. }\end{array}$ \\
\hline \multirow[t]{2}{*}{ Description } & $\begin{array}{l}\text { According to the RD 2606/1996 Art. 2.4, the Funds must provide the accounts to their members } \\
\text { and the BE each year. }\end{array}$ \\
\hline & $\begin{array}{l}\text { Annually, the financial statements, audited by independent auditors and approved by the } \\
\text { Management Committee, are made public. In addition to the financial statements, the annual } \\
\text { report contains a description of the Funds' activities, including bank restructuring. The annual } \\
\text { accounts have ample information for interested parties. They are made public on the website. }\end{array}$ \\
\hline Assessment & Observed. \\
\hline \multicolumn{2}{|l|}{ Comments } \\
\hline 8.2 .1 & $\begin{array}{l}\text { Financial statements, if any, should be audited by an independent auditor. Information on } \\
\text { accounting policies and any qualification to the statements should be an integral part of the } \\
\text { publicly disclosed financial statements. }\end{array}$ \\
\hline Description & $\begin{array}{l}\text { Financial statements are audited by independent external auditors. Information on accounting } \\
\text { policies, detailed notes on the accounts, and any qualification to the accounts, are an integral } \\
\text { part of the publicly disclosed financial statements. Complementary information on signed } \\
\text { contracts is remitted annually to the National Audit Office (Tribunal de Cuentas). }\end{array}$ \\
\hline Assessment & Observed. \\
\hline \multicolumn{2}{|l|}{ Comments } \\
\hline 8.2 .2 & $\begin{array}{l}\text { Internal governance procedures necessary to ensure the integrity of operations, including } \\
\text { internal audit arrangements, should be publicly disclosed. }\end{array}$ \\
\hline \multirow[t]{2}{*}{ Description } & $\begin{array}{l}\text { Management of the Funds is the responsibility of their Management Committees. The } \\
\text { Management Company manages the Funds' capital and is governed by the provisions of } \\
\text { contained in Law } 12 / 1991 \text { and the performance contracts signed with each Fund. }\end{array}$ \\
\hline & $\begin{array}{l}\text { Given the reduced size of the administrative units of the Funds ( } 15 \text { employees in total), they do } \\
\text { not have internal audit. However, the Management Company has a Controlling Council made } \\
\text { up of three members representing each the type of bank covered by the Funds with internal } \\
\text { control functions. Information on this organizational structure is disclosed on the website and in } \\
\text { the annual report. The organization and functions are based on internal regulation, such as the } \\
\text { "Norms on Organization and functions of the Management Company" and the "Rules on the } \\
\text { Functions of the Controlling Council," and on the performance contract with the funds. These } \\
\text { internal governance procedures, such as those governing decisions and accountability, are not } \\
\text { made public. }\end{array}$ \\
\hline Assessment & Partly observed. \\
\hline Comments & $\begin{array}{l}\text { The FDG should publish information on its internal governance procedures in order to obtain an } \\
\text { observed rating. }\end{array}$ \\
\hline 8.3 & $\begin{array}{l}\text { Where applicable, information on the operating expenses and revenues of financial } \\
\text { agencies should be publicly disclosed annually. }\end{array}$ \\
\hline Description & $\begin{array}{l}\text { Detailed notes on the accounts and any qualification to the statements are integral part of the } \\
\text { publicly disclosed financial statements. }\end{array}$ \\
\hline Assessment & Observed. \\
\hline Comments & \\
\hline
\end{tabular}




\begin{tabular}{|c|c|}
\hline 8.4 & $\begin{array}{l}\text { Standards for the conduct of personal financial affairs of officials and staff of financial } \\
\text { agencies and rules to prevent exploitation of conflicts of interest, including any general } \\
\text { fiduciary obligation, should be publicly disclosed. }\end{array}$ \\
\hline \multirow[t]{3}{*}{ Description } & $\begin{array}{l}\text { RD 2606/1994 Art. } 2.7 \text { states that "the members of the Management Committee shall keep secret } \\
\text { all information they may obtain as a result of their participation in the activities of the Fund, and } \\
\text { they may not make use of such information for purposes other than those relating to the exercise } \\
\text { of their office on the Committee." }\end{array}$ \\
\hline & $\begin{array}{l}\text { Article } 2.1 \text { includes rules to avoid conflicts of interest and specifies that "in the case of bank } \\
\text { representatives, they must also be replaced upon request of the Committee chairman whenever } \\
\text { the Committee has to deal with matters directly relating to an institution or group of institutions } \\
\text { said representative is associated with as manager, executive, contractual employee or otherwise, } \\
\text { or any other relationship that may affect the objectivity of his decisions (...)." }\end{array}$ \\
\hline & This legislation is posted on the website. \\
\hline Assessment & Broadly observed. \\
\hline Comments & $\begin{array}{l}\text { Information on the standards of conduct of personal financial affairs should be publicly } \\
\text { disclosed by other means, in addition to legislation, for an observed rating. This is especially } \\
\text { important considering that the Management Committees includes four representatives from } \\
\text { market institutions that can be affected by problems in a financial entity. }\end{array}$ \\
\hline 8.4 .1 & $\begin{array}{l}\text { Information about legal protections for officials and staff of financial agencies in the conduct of } \\
\text { their official duties should be publicly disclosed. }\end{array}$ \\
\hline Description & $\begin{array}{l}\text { There is no legal protection for officials and staff of the Funds and Management Company in } \\
\text { the conduct of their official duties. }\end{array}$ \\
\hline Assessment & Not applicable. \\
\hline Comments & \\
\hline
\end{tabular}

Table 8. Summary Observance of IMF's MFP Transparency Code-Deposit Insurance Funds

\begin{tabular}{|c|c|c|}
\hline \multirow{2}{*}{$\begin{array}{l}\text { Assessment } \\
\text { Grade }\end{array}$} & \multicolumn{2}{|r|}{ Practices Grouped by Assessment Grade } \\
\hline & Count & List \\
\hline Observed & 22 & $\begin{array}{l}\text { 5.1; 5.1.1; 5.1.2; 5.1.3; 5.1.4; 5.2; 6.1; 6.1.1; 6.1.4; 6.1.5; 6.2; 6.3; 7.2; 7.3; } \\
\text { 7.3.1; 7.4; 7.4.1; 7.5; 7.6; 8.2; 8.2.1; 8.3 }\end{array}$ \\
\hline Broadly observed & 1 & 8.4 \\
\hline Partly observed & 3 & $7.4 .2 ; 8.1 ; 8.2 .2$ \\
\hline Non-observed & & \\
\hline Not applicable & 10 & $5.3 ; 5.3 .1 ; 5.4 ; 5.5 ; 6.1 .2 ; 6.1 .3 ; 6.4 ; 7.1 ; 7.7 ; 8.4 .1$ \\
\hline
\end{tabular}

\section{Recommended Action Plan and Authorities' Response to the Assessment}

\section{Recommended action plan}

29. The FGDs already adhere to almost all of the practices of the Transparency Code. To further refine transparency, the Deposit Insurance Funds may consider the following: 
- $\quad$ Developing a more proactive approach to informing the public. This includes a formal policy on public communications by senior FGD officials and on the release of the texts of public statements. Accountability would also be improved with a stated policy regarding the appearance of FGD officials before a designated public authority (e.g., parliament or a parliamentary committee). Such an arrangement would be especially relevant in case of bank restructuring actions by the FGD or differences of opinion on the subject between the FGD and the BE.

- Disseminating information (other than legislation) on internal governance procedures and standards of conduct of personal financial affairs. This is especially important considering that the Management Committees includes four representatives from institutions that can be affected by and have conflicts of interest in relation to problems in a financial entity.

Table 9. Recommended Action Plan to Improve Observance of IMF's MFP Transparency Code Practices-Deposit Insurance

\begin{tabular}{|l|l|}
\hline \multicolumn{1}{|c|}{ Reference Practice } & \multicolumn{1}{|c|}{ Recommended Action } \\
\hline $\begin{array}{l}\text { VII. Public Availability of } \\
\text { Information on Financial Policies }\end{array}$ & \\
\hline $\begin{array}{l}\text { 7.4.2 Senior financial agency } \\
\text { officials should be ready to explain } \\
\text { their institution's objective(s) and } \\
\text { performance to the public, and } \\
\text { have a presumption in favor of } \\
\text { releasing the text of their } \\
\text { statements to the public. }\end{array}$ & $\begin{array}{l}\text { Transparency would be enhanced by a more proactive approach to public } \\
\text { information. The FDG should develop a formal policy on public } \\
\text { communications by senior FGD officials and on the release of the texts of } \\
\text { public statements. }\end{array}$ \\
\hline $\begin{array}{l}\text { VIII. Accountability and } \\
\text { Assurance of Integrity by } \\
\text { Financial Agencies }\end{array}$ & \\
\hline $\begin{array}{l}\text { 8.1 Officials of financial agencies } \\
\text { should be available to appear } \\
\text { before a designated public } \\
\text { authority to report on the conduct } \\
\text { of financial policies, explain the } \\
\text { policy objective(s) of their } \\
\text { institution, describe their } \\
\text { performance in pursuing their } \\
\text { objective(s), and, as appropriate, } \\
\text { exchange views on the state of the } \\
\text { financial system. }\end{array}$ & $\begin{array}{l}\text { A stated policy regarding the appearance of FGD officials before a } \\
\text { designated public authority (e.g., parliament or a parliamentary committee) } \\
\text { would enhance accountability. Such an arrangement would be especially } \\
\text { relevant in case of bank restructuring actions FGD or in case of differences } \\
\text { of opinion on the subject between the FGD and the BE. }\end{array}$ \\
\hline $\begin{array}{l}\text { 8.2.2 Internal governance } \\
\text { procedures necessary to ensure the } \\
\text { integrity of operations, including } \\
\text { internal audit arrangements, should } \\
\text { be publicly disclosed. }\end{array}$ & $\begin{array}{l}\text { The FDG should publish information on its internal governance } \\
\text { procedures. }\end{array}$ \\
\hline
\end{tabular}




\begin{tabular}{|l|l|}
\hline \multicolumn{1}{|c|}{ Reference Practice } & \multicolumn{1}{|c|}{ Recommended Action } \\
\hline $\begin{array}{l}\text { 8.4 Standards for the conduct of } \\
\text { personal financial affairs of } \\
\text { officials and staff of financial } \\
\text { agencies and rules to prevent } \\
\text { exploitation of conflicts of interest, } \\
\text { including any general fiduciary } \\
\text { obligation, should be publicly } \\
\text { disclosed. }\end{array}$ & $\begin{array}{l}\text { Information (other than legislation) on standards of conduct of personal } \\
\text { financial affairs should be disclosed to the general public. This is especially } \\
\text { important considering that the Management Committees includes private } \\
\text { sector representatives that may be affected by and have conflicts of interest } \\
\text { in reblems in a financial entity. }\end{array}$ \\
\hline
\end{tabular}

\section{Authorities' response to the assessment}

30. The authorities are in broad agreement with the assessment but note that with reference to principle 7.4.2, they do not see a need to be more proactive in providing public information on deposit insurance because by law, the banks are obliged to do so. They point out that the cost of providing additional information to the public would be high in relation to its benefits. The authorities agree that in general, a well designed information program can enhance public confidence in credit institutions, but note that in the case of Spain, public confidence is already high and the launch of an information program on deposit insurance could have the opposite effect, that is, weaken confidence.

31. With regard to principle 8.1, the authorities are of the view that since the President of the FGD Management Company is the BE Deputy Governor, the BE has sufficient information about the funds that can be used as needed during appearances before parliament. The authorities consider the possibility of differences in opinion between the FGD and the BE on bank restructuring issues to be theoretical, as four of the eight members of the Management Committee are BE representatives, and the President, who is the BE Deputy Governor, has a deciding vote.

32. Regarding public disclosure of internal control regulations (8.2.2), the authorities are of the view that the composition of the governing bodies of both the funds and the Management Company ensure the transparency of, and control over, their actions.

\section{Payment Systems OVersight}

\section{A. Information and Methodology Used for Assessment}

33. An evaluation of observance of good transparency practices related to payment systems oversight was carried out as part of the joint Fund-Bank Financial Sector Assessment Program (FSAP). The assessment was based on the IMF Code of Good Practices on Transparency in Monetary and Financial Policies (MFP Transparency Code). It was undertaken during June- July 2005 and was based on: (a) relevant laws; (b) information made available on the BE website; (c) information available in the BE's Annual Report and other publications; (d) responses to a pre-FSAP questionnaire; (e) extensive discussions with BE officials; and (f) discussions with commercial banks and bankers' associations. 
34. The Spanish authorities cooperated fully with the assessment and provided all the necessary clarifications and documents.

\section{B. Institutional and Market Structure}

35. Payment systems oversight in Spain is based on a legal and regulatory framework established at the European level as well as on the Law of Autonomy of the BE (Law 13/1994, LABE). It encompasses Spain's contribution to the oversight of pan-European systems such as the Trans-European Automated Real-time Gross Settlement Express Transfer System (TARGET), Clearnet, and the Euroclear group, as well as the oversight of purely domestic systems such as the SLBE for large-value payments and the SNCE for lowvalue payments for which the BE bears sole responsibility. Iberclear, which is in charge of both registration and clearing and settlement of trades on the stock exchange, is supervised by the CNMV.

36. The Payment Systems Department (PSD) of the Directorate General of Operations, Markets, and Payment Systems (DGO) performs the payment system oversight function of the BE. The PSD carries out these activities under the directions of the Governing Council pursuant to the LABE, which specifies the responsibility to "oversee the functioning of clearing and payment systems. To that end, it may seek to obtain whatever information and documents it deems necessary to assess the efficiency and security of payment systems and instruments both from the payment-system managing entity and from the suppliers of payment services, including those entities providing technological services for such systems and services." The Internal Regulations of the BE (RIBE) and relevant legislation are disclosed on the website.

37. The Directorate General of Operations, Markets, and Payment Systems is one of five BE Directorates. The Governing Council of the BE is composed of the Governor, the Deputy Governor, six members elected by the government, the Director General of Treasury and Financial Policy under the ME, and the vice president of the CNMV. The BE Director Generals of the Bank as well as a staff representative selected according to internal rules attend Council meetings in a nonvoting capacity. ${ }^{4}$

38. The Communications Department disseminates policy decisions and policy announcements, provides information on the operating framework and objectives, publishes texts of major speeches by senior officials, data, and research reports, arranges seminars and maintains contacts with the media. The BE website (www.bde.es) contains general information, legislation and regulation, statistics, publications, and so on. It is available in both Spanish and English.

\footnotetext{
${ }^{4}$ For a complete description of the institutional and macro-prudential setting, see the Assessment of Observance of the Core Principles for Systemically Important Payment Systems in Spain.
} 


\section{Practice-by-Practice Assessment}

39. The detailed assessment recognizes that payment system oversight and the legal and institutional framework differ from one country to another, as do the domestic circumstances. The assessment of observance with each practice of the MFP Transparency Code is based on existing laws, regulations, and practices. A five-part assessment system is used: Observed; broadly observed; partly observed; not observed; and not applicable: observed, implying full observance or with insignificant shortcomings; broadly observed, where minor weaknesses exist and these are not seen as being of a significant nature so as to raise serious doubts about the authority's ability to achieve the objective of that practice; partly observed, where shortcomings are sufficient to raise doubts about the authority's ability to achieve observance and which could affect the operational process and effectiveness of financial policies; not observed, where the practice is not being observed and no substantive progress has been recorded toward achieving the objectives of the practice; and not applicable, where, due to the country circumstances and the institutional and legal framework, the transparency practice is not applicable.

Table 10. Observance of IMF's MFD Transparency Code-Payment System Oversight

\section{Clarity OF Roles, ResponsibILITIES, AND ObJeCTIVES OF FinANCIAL AgENCIES RESPONSIBLE FOR} FinanCial Policies

\begin{tabular}{|l|l|}
\hline 5.1 & $\begin{array}{l}\text { The broad objective(s) and institutional framework of financial agencies should be clearly } \\
\text { defined, preferably in relevant legislation or regulation. }\end{array}$ \\
\hline Description & $\begin{array}{l}\text { The BE's institutional framework is legislated in the Law of Autonomy of the Bank of Spain } \\
\text { (Law 13/1994, LABE), where Art. 1 states that "the Bank is an institution under public law } \\
\text { with its own legal personality and full public and private legal capacity. It shall pursue its } \\
\text { activities and fulfill its objectives with autonomy from the administration, carrying out its } \\
\text { functions as specified in this law and other legislation" and that "The Bank is an integral part of } \\
\text { the European System of Central Banks (ESCB) and shall be subject to the provisions of the } \\
\text { Treaty of the European Community ("Treaty") and to the Statutes of the ESCB." } \\
\text { The main law governing payment systems is the Law on Settlement Finality (Law 41/1999). } \\
\text { Pursuant to this law, the overseers are the BE for payment systems and the CNMV for } \\
\text { securities settlement systems. } \\
\text { The functions of the BE, including oversight of payment systems, are also described in Art. } 3 \text { of } \\
\text { the Internal Regulation of Bank of Spain (RIBE). The operation of payment systems and the } \\
\text { oversight are in different divisions of the Directorate-General of Operations, Markets, and } \\
\text { Payment Systems (DGO). } \\
\text { The broad objectives of the BE are defined in Art 7.2 of LABE: "Without prejudice to its } \\
\text { main objective of maintaining price stability and fulfilling its duties as a member of the ESCB } \\
\text { in accordance with the terms of article 105.1 of the Treaty, the Bank shall support the general } \\
\text { economic policy of the government." }\end{array}$ \\
\hline Assessment & \begin{tabular}{l} 
Observed. \\
\hline Comments
\end{tabular} \\
\hline
\end{tabular}




\begin{tabular}{|c|c|}
\hline 5.1 .1 & The broad objective(s) of financial agencies should be publicly disclosed and explained. \\
\hline \multirow[t]{5}{*}{ Description } & $\begin{array}{l}\text { The objective, responsibility, and authority of payment system oversight are further regulated } \\
\text { in both European and national legislation. Pursuant to Art. 105(2) of the European Community } \\
\text { Treaty (the Treaty) and Art. 3(1) of the Statutes of the European System of Central Banks (the } \\
\text { Statutes), one of the basic functions of the ESCB is to "promote the smooth functioning of the } \\
\text { payment system." In addition, Art. } 22 \text { of the Statutes establishes that "the ECB and the national } \\
\text { central banks can provide means and the ECB dictate rules assigned to guarantee efficient and } \\
\text { secure clearing and settlement systems in the Community, as well as with other countries." }\end{array}$ \\
\hline & $\begin{array}{l}\text { The objective to promote the smooth functioning of the payment systems through efficiency } \\
\text { and security are also recognized in national legislation. Art. 7.of } 3 \text { LABE states that "the Bank } \\
\text { shall participate in the fulfillment of the following basic functions attributed to the ESCB: (...) } \\
\text { To promote the smooth functioning of the payment system." In addition, Art. } 7.5 \text { states that } \\
\text { "the Bank shall, moreover, perform the following functions: (...) Promote the smooth operation } \\
\text { and the stability of the financial system and, without prejudice to the terms of 3.d) above, of } \\
\text { national payment systems." }\end{array}$ \\
\hline & $\begin{array}{l}\text { Article } 16 \text { of LABE specifies among BE's objectives "to promote the sound functioning of } \\
\text { payment systems (...)." }\end{array}$ \\
\hline & $\begin{array}{l}\text { The BE also posted on its website/Payment systems a formal declaration on its payment } \\
\text { system oversight role (El Banco de España y la Vigilancia de los Sistemas de Pago). This is } \\
\text { written in a non-technical manner and accompanied by a statement to the press. The declaration } \\
\text { is also included in the BE's } 2005 \text { Financial Stability Review. }\end{array}$ \\
\hline & $\begin{array}{l}\text { In addition, the BE has issued a institutional pamphlet called The Bank of Spain and the } \\
\text { Payment Systems, which has been distributed at relevant national and international events. Until } \\
\text { the issuance of the declaration mentioned above, the text of the pamphlet was posted on the } \\
\text { website. From the payment system section of the BE website is also a link to the ECB } \\
\text { declaration Role of the Eurosystem in the Field of Payment Systems Oversight. }\end{array}$ \\
\hline Assessment & Observed. \\
\hline \multicolumn{2}{|l|}{ Comments } \\
\hline 5.1 .2 & $\begin{array}{l}\text { The responsibilities of the financial agencies and the authority to conduct financial policies } \\
\text { should be publicly disclosed. }\end{array}$ \\
\hline \multirow[t]{5}{*}{ Description } & $\begin{array}{l}\text { The main responsibilities with respect to the payment system oversight are mentioned in Arts. } 3 \\
\text { and } 22 \text { of the Statutes and Arts } 7 \text { and } 16 \text { of LABE. }\end{array}$ \\
\hline & Responsibilities with respect to payment systems are specified in Art. 16 of LABE: \\
\hline & $\begin{array}{l}\text { " } 1 \text {. To promote the sound functioning of payment systems and in the exercise of its functions as } \\
\text { a member of the European System of Central Banks, the Bank of Spain shall, by means of a } \\
\text { Circular, regulate payment clearing and settlement systems. In particular, it may implement or } \\
\text { complement the legal framework prescribed by the European Central Bank and include the } \\
\text { recommendations of international bodies on principles applicable to the security and efficiency } \\
\text { of payment systems and instruments. Where appropriate, it may also manage the related } \\
\text { payment clearing and settlement systems. }\end{array}$ \\
\hline & $\begin{array}{l}\text { 2. The Bank of Spain shall oversee the functioning of clearing and payment systems. To that } \\
\text { end, it may request whatever information and documents it deems necessary to assess the } \\
\text { efficiency and security of payment systems and instruments both from the payment system } \\
\text { managing entity and from the suppliers of payment services, including those entities providing } \\
\text { technological services for such systems and services." }\end{array}$ \\
\hline & $\begin{array}{l}\text { This legislation is made public (see 5.1.1). In addition to the objectives, the documents also } \\
\text { describe the responsibilities and tools available to the BE has to fulfill those responsibilities. }\end{array}$ \\
\hline
\end{tabular}




\begin{tabular}{|c|c|}
\hline Assessment & Observed. \\
\hline \multicolumn{2}{|l|}{ Comments } \\
\hline 5.1 .3 & $\begin{array}{l}\text { Where applicable, the broad modalities of accountability for financial agencies should be } \\
\text { publicly disclosed. }\end{array}$ \\
\hline \multirow[t]{3}{*}{ Description } & $\begin{array}{l}\text { Article } 10 \text { of LABE specifies the BE's responsibility to report on monetary policy to Parliament } \\
\text { and the government, so that these institutions can monitor and debate the monetary policy being } \\
\text { pursued on a regular basis. " } 1 \text {. The Bank shall regularly inform Parliament and the } \\
\text { government of the objectives and the implementation of monetary policy, without prejudice to } \\
\text { the terms of article } 107 \text { of the Treaty and the ECB rules on professional secrecy. To this end, } \\
\text { the Governor of the Bank may be asked to appear, in accordance with Parliamentary } \\
\text { regulations, before any Congress or Senate committee or joint committee of both chambers, or } \\
\text { be asked to attend for this purpose cabinet meetings or meetings of its Commission for } \\
\text { Economic Affairs. } 2 \text {. In addition, the Governor of the Bank may be asked to attend the meetings } \\
\text { of the Consejo de Politica Fiscal y Financiera de las Comunidades Autónomas referred to in } \\
\text { article } 3 \text { of Organic Law } 8 / 1980 \text {, of September } 22 \text {, on Financing of Autonomous Communities } \\
\text { and to report on issues within the scope of the Bank's authority, with a view to facilitating the } \\
\text { tasks of financial coordination of the above-mentioned Consejo." }\end{array}$ \\
\hline & $\begin{array}{l}\text { Articles } 4 \text { of LABE and } 33 \text { of RIBE state that "the government, upon proposal by the Minister of } \\
\text { Economy and Finance, shall have the authority to approve the annual balance sheet and } \\
\text { accounts of the Bank, which will be sent to Parliament for informational purposes. Without } \\
\text { prejudice to the terms of article } 27 \text { of the Statutes of the ESCB, the Bank shall be subject to } \\
\text { external auditing by the National Audit Tribunal, under the terms of Organic Law } 2 / 1982 \text {, of } \\
\text { May } 12 \text {, on the National Audit Office. The report accompanying the annual balance sheet and } \\
\text { accounts shall give further detail on different operations or items on the balance sheet, } \\
\text { according to their characteristics. In particular, the Bank's contributions to the Deposit } \\
\text { Guarantee Funds shall be detailed, as will any loans or other operations transacted for the } \\
\text { benefit of any other institution or person not on an arm's-length basis, or which in any other } \\
\text { way involve loss of profit or losses for the Bank. In such cases the amount of such loss of profit } \\
\text { or losses shall be specified." Art. } 21.1 \text { c states that "the Governing Council shall approve, at the } \\
\text { proposal of the Executive Commission, the annual report of the Bank and, as relevant, any other } \\
\text { reports which the Bank must submit to Parliament, to the government or to the Economy and } \\
\text { Finance Minister." }\end{array}$ \\
\hline & $\begin{array}{l}\text { This accountability framework applies to all of the BE's areas of responsibility, including } \\
\text { payment systems oversight. All the mentioned legislation has been made public in the BOE and } \\
\text { is available on BE's website. }\end{array}$ \\
\hline Assessment & Observed. \\
\hline \multicolumn{2}{|l|}{ Comments } \\
\hline 5.1 .4 & $\begin{array}{l}\text { Where applicable, the procedures for appointment, terms of office, and any general criteria for } \\
\text { removal of the heads and members of the governing bodies of financial agencies should be } \\
\text { publicly disclosed. }\end{array}$ \\
\hline \multirow[t]{2}{*}{ Description } & $\begin{array}{l}\text { Articles } 24 \text { and } 25 \text { of LABE establish the procedure for appointment, the terms, and the criteria } \\
\text { for removal of the heads and members of the governing bodies. }\end{array}$ \\
\hline & $\begin{array}{l}\text { Article } 24 \text { states that the BE Governor shall be appointed by the King following a proposal by } \\
\text { the head (President) of government. Nominees shall be Spanish and have recognized } \\
\text { competence in monetary and/or banking matters. Prior to the appointment of the Governor, the } \\
\text { Economy and Finance Minister shall appear before the relevant parliamentary committee under } \\
\text { the terms envisaged in article } 203 \text { of the Spanish Parliamentary Internal Regulations, to report } \\
\text { on the proposed candidate. The Deputy Governor shall be appointed by the government }\end{array}$ \\
\hline
\end{tabular}




\begin{tabular}{|c|c|}
\hline & $\begin{array}{l}\text { following a proposal by the Governor and must meet the same conditions as the Governor. } \\
\text { The six elected Council members shall be appointed by the government following a proposal by } \\
\text { the Minister of the ME, after consultation with the Governor of the BE. They must be Spanish } \\
\text { and have recognized competence in the area of economy or law. }\end{array}$ \\
\hline & $\begin{array}{l}\text { Article } 25 \text { defines the terms of office and criteria for dismissal of members of governing bodies. } \\
\text { "The terms of office of the Governor and the Deputy Governor will be simultaneous, for a } \\
\text { period of six years, and non-renewable for the same position. Elected Council members will } \\
\text { serve a six-year term and may be reappointed once. The Governor, the Deputy Governor and } \\
\text { elected Council members shall leave office for the following reasons: }\end{array}$ \\
\hline & a. "Expiration of their terms of office. \\
\hline & $\begin{array}{l}\text { b. Resignation, which will take effect once the government is notified or, in the case of a } \\
\text { member of the Executive Commission, when the Governing Council is notified. }\end{array}$ \\
\hline & c. Reaching seventy years of age. \\
\hline & $\begin{array}{l}\text { d. Dismissal decided by the government, due to permanent incapacity to perform their } \\
\text { functions, serious lack of compliance with their obligations, incompatibility that may have } \\
\text { arisen during the term of office, or prosecution for deliberate crimes." }\end{array}$ \\
\hline & Article 26 defines the incompatibilities. \\
\hline & $\begin{array}{l}\text { 1. "The Governor and the Deputy Governor shall be subject to the system of incompatibilities } \\
\text { applicable to senior officials. Their posts shall also be incompatible with the exercise of any } \\
\text { public or private profession or activity, unless these are inherent to their status or are imposed } \\
\text { as part of their role as representatives of the Bank. Once their term of office ends, over the next } \\
\text { two years they may not engage in any professional activity linked to credit institutions or } \\
\text { securities markets. }\end{array}$ \\
\hline & $\begin{array}{l}\text { 2. Elected Council members may not be involved in professional activities linked to credit } \\
\text { institutions of any type, to securities markets or to private financial institutions during their } \\
\text { terms in office. Serving on the Bank Council is compatible with teaching and research } \\
\text { activities". These aspects are also elaborates in the RIBE. }\end{array}$ \\
\hline & $\begin{array}{l}\text { There are no special rules for the Director General of Banking Supervision. However, Art. } 6 \\
\text { (secrecy) and art } 26.2 \text { (other professional activities) apply also to all General Directors (LABE } \\
\text { Art. 30). These aspects are also elaborated in the RIBE. }\end{array}$ \\
\hline & $\begin{array}{l}\text { All the mentioned legislation and RIBE have been made public in the BOE and are available on } \\
\text { the BE website. }\end{array}$ \\
\hline Assessment & Observed. \\
\hline Comments & \\
\hline 5.2 & The relationship between financial agencies should be publicly disclosed. \\
\hline Description & $\begin{array}{l}\text { Article } 7.8 \text { of LABE states that "the Bank may establish relationships with other central banks, } \\
\text { with financial supervisory authorities and financial institutions in other countries, and with } \\
\text { international monetary and financial organizations. It may also establish relationships with } \\
\text { public financial institutions and regional financial supervisory authorities." }\end{array}$ \\
\hline & $\begin{array}{l}\text { Disclosure of the relationship between the BE and the ECB and other central banks within } \\
\text { the Eurosystem is of special importance. In this respect, Art. } 1.3 \text { of LABE establishes that "the } \\
\text { Bank is an integral part of the European System of Central Banks ("ESCB") and shall be } \\
\text { subject to the provisions of the Treaty of the European Community ("Treaty") and to the } \\
\text { Statutes of the ESCB. In the exercise of the functions arising from its status as an integral part } \\
\text { of the ESCB, the Bank shall follow the guidelines and instructions emanating from the } \\
\text { European Central Bank ("ECB") under the terms of the aforementioned provisions." }\end{array}$ \\
\hline & $\begin{array}{l}\text { The Bank of Spain has full responsibility for national payment system oversight (LABE). } \\
\text { Since December 2004, Spain has two payment systems, the SLBE for large-value payments }\end{array}$ \\
\hline
\end{tabular}




\begin{tabular}{|c|c|}
\hline & $\begin{array}{l}\text { (operated by the BE) and the SNCE for low-value payments. Iberclear, which is in charge of } \\
\text { both the register and the clearing and settlement of all trades from the stock exchange, is } \\
\text { supervised by the CNMV (LMV). The supervisory powers over national payment systems are } \\
\text { disclosed on BE's website, while the supervisory powers over Iberclear are disclosed in CNMV } \\
\text { Annual Report on Activities and on the Iberclear's website. } \\
\text { The possibility to sign national agreements between supervisors is recognized in D.A. } 2 \text { of the } \\
\text { Financial Law (Law 44/2002), which points to an obligation of cooperation between the BE, the } \\
\text { CNMV, and the ME to harmonize supervision practices and criteria and to exchange relevant } \\
\text { information. The BE, the CNMV, and the ME also cooperate and exchange information } \\
\text { (Arts. } 17 \text { of LMV and } 20 \text { of LABE) through cross-membership in governing bodies (the BE } \\
\text { deputy governor is an advisor in CNMV council and the Director General of Treasury and } \\
\text { Financial Policy and the CNMV vice president are members of BE governing council). In } \\
\text { addition, the BE has signed agreements with the CNMV (June 9, 2004) and the DGS } \\
\text { (March 12, 2004). New agreements are made public in the Management Report of BE's Annual } \\
\text { Report. } \\
\text { New legislation relevant to the relationship among financial agencies is made public through } \\
\text { publication in the official gazette of the European Communities (the Official Journal, OJ) for } \\
\text { EU legislation and the BOE for national legislation. The legislation is also available on the ECB } \\
\text { and BE websites. }\end{array}$ \\
\hline Assessment & Observed. \\
\hline Comments & \\
\hline 5.3 & $\begin{array}{l}\text { The role of oversight agencies with regard to payment systems should be publicly } \\
\text { disclosed. }\end{array}$ \\
\hline Description & $\begin{array}{l}\text { New legislation relevant to payment system oversight objectives is published in the Official } \\
\text { Gazette of the European Communities for EU legislation and the State BOE for national } \\
\text { legislation. The legislation is also available on the ECB and BE websites. } \\
\text { The BE also posted on its website/Payment systems a formal declaration on its payment } \\
\text { system oversight role (El Banco de España y la Vigilancia de los Sistemas de Pago). This is } \\
\text { written in a non-technical manner and accompanied by a statement to the press. The declaration } \\
\text { is also included in the BE's } 2005 \text { Financial Stability Review. } \\
\text { In addition, the BE has issued a institutional pamphlet called The Bank of Spain and the } \\
\text { Payment Systems, which has been distributed at relevant national and international events. Until } \\
\text { the issuance of the declaration mentioned above, the text of the pamphlet was posted on the } \\
\text { website. From the payment system section of the BE website is also a link to the ECB } \\
\text { declaration Role of the Eurosystem in the Field of Payment Systems Oversight. }\end{array}$ \\
\hline Assessment & Observed. \\
\hline Comments & \\
\hline 5.3 .1 & $\begin{array}{l}\text { The agencies overseeing payment systems should promote the timely public disclosure of } \\
\text { general policy principles (including risk management policies) that affect the robustness of } \\
\text { systemically important payment systems. }\end{array}$ \\
\hline Description & $\begin{array}{l}\text { The general policy principles related to payment systems are described in legislation (ESCB } \\
\text { Statute and LABE), which are made public through press and websites. } \\
\text { In addition, the Eurosystem, which the BE is part of, regularly communicates payment system } \\
\text { standards and principles to the public, including the CPSS Core Principles for Systemically } \\
\text { Important Payment Systems, adopted in 2001. Other documents linked from the payment } \\
\text { systems section of the BE website are Oversight Criteria for Low-value Payment Systems in } \\
\text { Euro, the Report on Electronic Money, and the Report on the objectives of electronic money }\end{array}$ \\
\hline
\end{tabular}




\begin{tabular}{|c|c|}
\hline & $\begin{array}{l}\text { systems security. } \\
\text { The BE usually publishes in Spanish ECB press releases accompanying new documents. } \\
\text { Information on the risk management policies of the SLBE (large-value payments) and the } \\
\text { SNCE (low-value payments) is also described and explained on the website/Payment } \\
\text { systems/SLBE and /SNCE, respectively. The BE reports each year on its payments systems } \\
\text { activities in the management report section of the Annual Report. }\end{array}$ \\
\hline Assessment & Observed. \\
\hline \multicolumn{2}{|l|}{ Comments } \\
\hline 5.4 & $\begin{array}{l}\text { Where financial agencies have oversight responsibilities for self-regulatory organizations } \\
\text { (e.g., payment systems), the relationship between them should be publicly disclosed. }\end{array}$ \\
\hline \multirow[t]{2}{*}{ Description } & $\begin{array}{l}\text { The BE's objectives within regard to payment system oversight are communicated clearly to } \\
\text { the public in the document The Bank of Spain and Payment Systems Oversight. The BE has } \\
\text { oversight responsibilities over both SLBE and SNCE, but only operates the former. Since 2004, } \\
\text { the SNCE is operated by the Sociedad Española de Sistemas de Pago S.A. (SESP), a self- } \\
\text { regulatory organization owned by the banking system. }\end{array}$ \\
\hline & $\begin{array}{l}\text { The nature, functions, juridical regime, and oversight regime of the SESP are regulated in } \\
\text { Chapter II of the Law on Payment and Securities Settlement Systems (Law } 41 / 1999 \text { as modified } \\
\text { by Law 2/2004). Article } 17.3 \text { establishes with clarity the relationship between the BE and the } \\
\text { SESP, defining the BE as the corresponding supervisor. The basic legislation defining the } \\
\text { functions of the systems is published in the BOE. Relevant laws are available on the website. }\end{array}$ \\
\hline Assessment & Observed. \\
\hline Comments & $\begin{array}{l}\text { Before the reforms of } 2004 \text {, the BE had oversight responsibilities over SPI (Interbank Payment } \\
\text { Service), which exchanging large-value payment orders from abroad. The relationship between } \\
\text { the BE and SPI was clearly defined in the earlier version of Law } 41 / 1994 \text {. }\end{array}$ \\
\hline 5.5 & $\begin{array}{l}\text { Where self-regulatory organizations are authorized to perform part of the regulatory and } \\
\text { supervisory process, they should be guided by the same good transparency practices } \\
\text { specified for financial agencies. }\end{array}$ \\
\hline \multirow[t]{2}{*}{ Description } & $\begin{array}{l}\text { The only national payment system not operated by the BE is the SNCE, whose administration } \\
\text { was transferred to the SESP in 2004. The nature, functions, juridical regime and oversight } \\
\text { regime of the SESP is regulated in Chapter II of the Law on Payment and Securities Settlement } \\
\text { Systems as described in 5.4. }\end{array}$ \\
\hline & $\begin{array}{l}\text { The BE has the power to approve the by-laws as well as the general regulations affecting } \\
\text { SNCE. The law also requires the publication of regulations in the BOE. }\end{array}$ \\
\hline Assessment & Observed. \\
\hline \multicolumn{2}{|l|}{ Comments } \\
\hline \multicolumn{2}{|r|}{ VI. OPEN Process for Formulating ANd RePorting of FinanCial Policies } \\
\hline 6.1 & $\begin{array}{l}\text { The conduct of policies by financial agencies should be transparent, compatible with } \\
\text { confidentiality considerations and the need to preserve the effectiveness of actions by } \\
\text { regulatory and oversight agencies. }\end{array}$ \\
\hline Description & $\begin{array}{l}\text { The BE's policy is to be as open and transparent as possible about its payment system oversight } \\
\text { work. The regulatory framework governing the conduct of payment systems policies is } \\
\text { explained in LABE Art. 16. The LABE specifies the actions to be taken by the BE. New } \\
\text { legislation relevant to payment systems and payment systems oversight is published in the OJ } \\
\text { for EU legislation and the BOE for national legislation. The legislation is also available to the } \\
\text { public through the ECB and BE websites. }\end{array}$ \\
\hline
\end{tabular}




\begin{tabular}{|c|c|}
\hline Assessment & Observed. \\
\hline \multicolumn{2}{|l|}{ Comments } \\
\hline 6.1 .1 & $\begin{array}{l}\text { The regulatory framework and operating procedures governing the conduct of financial policies } \\
\text { should be publicly disclosed and explained. }\end{array}$ \\
\hline \multirow[t]{4}{*}{ Description } & $\begin{array}{l}\text { The regulatory framework governing the conduct of payment systems oversight is explained in } \\
\text { LABE Arts. } 7 \text { and } 16 \text { and in the ESCB Statutes Arts. } 3 \text { and } 22 . \text { The operating procedures are } \\
\text { covered in the LABE. The law is available on the BE website. }\end{array}$ \\
\hline & $\begin{array}{l}\text { New legislation relevant to payment system oversight objectives is made public through } \\
\text { publication in the OJ for EU legislation and the BOE for national legislation. The legislation is } \\
\text { also available to the public on the ECB and BE websites. }\end{array}$ \\
\hline & $\begin{array}{l}\text { The BE also posted on its website/Payment systems a formal declaration on its payment } \\
\text { system oversight role (El Banco de España y la Vigilancia de los Sistemas de Pago). This is } \\
\text { written in a non-technical manner and accompanied by a statement to the press. The declaration } \\
\text { is also included in the BE's } 2005 \text { Financial Stability Review. }\end{array}$ \\
\hline & $\begin{array}{l}\text { In addition, as part of the Eurosystem, the BE applies the rules and procedures for payment } \\
\text { system oversight agreed to within the system. These rules are communicated to the public } \\
\text { through both BE and ECB publications, as well as the publication of documents on the ECB } \\
\text { and BE websites. For example, The Role of the Eurosystem in Payment System Oversight and } \\
\text { Oversight Criteria for Low-value Payment Systems in Euro are published by the ECB and are } \\
\text { available through links on the BE website. }\end{array}$ \\
\hline Assessment & Observed. \\
\hline \multicolumn{2}{|l|}{ Comments } \\
\hline 6.1 .2 & $\begin{array}{l}\text { The regulations for financial reporting by financial institutions to financial agencies should be } \\
\text { publicly disclosed. }\end{array}$ \\
\hline \multirow[t]{2}{*}{ Description } & $\begin{array}{l}\text { BE Circular 4/2004 regulates information provided to the supervisor and models of financial } \\
\text { statements and has adapted the Spanish accounting regime to IFRS standards. }\end{array}$ \\
\hline & The regulation is made public by the $\mathrm{BE}$ in its publications and on the website. \\
\hline Assessment & Not applicable. \\
\hline Comments & Financial reporting by financial institutions is made to the DGS, not the DGO, within the BE. \\
\hline 6.1 .3 & $\begin{array}{l}\text { The regulations for the operation of organized financial markets (including those for issuers of } \\
\text { traded financial instruments) should be publicly disclosed. }\end{array}$ \\
\hline Description & $\begin{array}{l}\text { The regulations for the operation of organized financial markets (including those for issuers of } \\
\text { traded financial instruments) are publicly disclosed by the CNMV. }\end{array}$ \\
\hline Assessment & Not applicable \\
\hline Comments & $\begin{array}{l}\text { The BE, in its payment system oversight role, does not issue regulations on the operation of } \\
\text { organized financial markets. }\end{array}$ \\
\hline 6.1 .4 & $\begin{array}{l}\text { Where financial agencies charge fees to financial institutions, the structure of such fees should } \\
\text { be publicly disclosed. }\end{array}$ \\
\hline \multicolumn{2}{|l|}{ Description } \\
\hline Assessment & Not applicable. \\
\hline Comments & The BE, in its payment systems oversight role, does not charge fees to financial institutions. \\
\hline
\end{tabular}




\begin{tabular}{|c|c|}
\hline 6.1 .5 & $\begin{array}{l}\text { Where applicable, formal procedures for information sharing and consultation between } \\
\text { financial agencies (including central banks), domestic and international, should be publicly } \\
\text { disclosed. }\end{array}$ \\
\hline \multirow[t]{3}{*}{ Description } & $\begin{array}{l}\text { Due to the BE's role in the Eurosystem, the relationship between the BE, the ECB, and national } \\
\text { central banks in the euro area is of special importance. Hence, it serves as a formal framework } \\
\text { for information sharing and consultations among these institutions (see 5.2). }\end{array}$ \\
\hline & $\begin{array}{l}\text { Another aspect refers to the relationship between the payment systems and banking supervision. } \\
\text { The BE signed a EU protocol in } 2001 \text { on cooperation among agencies responsible for payment } \\
\text { system oversight and banking supervision, in its double role as responsible for both. In } 2003 \text {, } \\
\text { the BE signed a memorandum establishing high level principles for cooperation in crisis } \\
\text { management among national central banks and the bank supervisors of the European union. The } \\
\text { signing of both memoranda were communicated to the public through ECB press releases } \\
\text { posted on both the ECB and BE websites. The press releases include an explanation on the need } \\
\text { for and content of the memoranda. }\end{array}$ \\
\hline & $\begin{array}{l}\text { In addition, the BE signed agreements with the CNMV (June 9, 2004) and the DGSFP } \\
\text { (March 12, 2004). These were made public in the Management Report of the BE Annual } \\
\text { Report. }\end{array}$ \\
\hline Assessment & Broadly observed. \\
\hline Comments & $\begin{array}{l}\text { In order to get an observed rating, the content of the MoUs should be made public, not only the } \\
\text { year they were signed. }\end{array}$ \\
\hline 6.2 & $\begin{array}{l}\text { Significant changes in financial policies should be publicly announced and explained in a } \\
\text { timely manner. }\end{array}$ \\
\hline \multirow[t]{3}{*}{ Description } & $\begin{array}{l}\text { As part of the Eurosystem, the BE applies the rules and procedures for payment system } \\
\text { oversight agreed to within the system. These rules are communicated to the public through both } \\
\text { BE and ECB publications, as well as the publication of several oversight documents on the } \\
\text { ECB and BE websites. Significant changes in financial policies are adopted and communicated } \\
\text { by the BE on behalf of the ESCB. The changes are publicly announced and explained in a } \\
\text { timely manner, through press releases and publication on the website. On the website the BE } \\
\text { does not only publish its own press releases, but the ECB's, translated into Spanish. In addition } \\
\text { the ECB president and vice president explain their decisions at a press conference held after the } \\
\text { monthly meeting. }\end{array}$ \\
\hline & $\begin{array}{l}\text { In the national context, the BE publicly announces and explains significant changes in financial } \\
\text { policies through the Annual Report, the website, notas informativas, monthly publications, and } \\
\text { press releases. Major changes are published in the BOE the day following such decisions. The } \\
\text { BE maintains a Q\&A system on the website to answer queries from the public. For example, } \\
\text { the already mentioned The Bank of Spain and Payment System Oversight was approved by the } \\
\text { Executive Committee and made public through a press release and posting on the website. }\end{array}$ \\
\hline & $\begin{array}{l}\text { In addition, payment system decisions are discussed with affected financial entities in a high } \\
\text { level payment systems group, chaired by a BE representative, that meets regularly (see } 6.4 \text { ). }\end{array}$ \\
\hline Assessment & Observed. \\
\hline \multicolumn{2}{|l|}{ Comments } \\
\hline 6.3 & $\begin{array}{l}\text { Financial agencies should issue periodic public reports on how their overall policy } \\
\text { objectives are being pursued. }\end{array}$ \\
\hline Description & $\begin{array}{l}\text { Until now, the BE has only sporadically issued reports on how their overall policy objectives } \\
\text { are being pursued, such as The Bank of Spain and Payment Systems Oversight. } \\
\text { In the Management Report section of BE's Annual Report only the operation of payment }\end{array}$ \\
\hline
\end{tabular}




\begin{tabular}{|c|c|}
\hline & systems is described, not the oversight activities. \\
\hline Assessment & Partly observed. \\
\hline Comments & $\begin{array}{l}\text { Periodic reports on how objectives are being pursued are required for an observed rating. The } \\
\text { payment system oversight activities should also be mentioned in the BE's Management Report. }\end{array}$ \\
\hline 6.4 & $\begin{array}{l}\text { For proposed substantive technical changes to the structure of financial regulations, there } \\
\text { should be a presumption in favor of public consultations, within an appropriate period. }\end{array}$ \\
\hline \multirow[t]{5}{*}{ Description } & $\begin{array}{l}\text { The legislative framework requires public debate and consultations with affected sectors. } \\
\text { Relevant legislation is posted on the BE website. }\end{array}$ \\
\hline & $\begin{array}{l}\text { Articles } 3.2 \text { of LABE and } 8.5 \text { of RIBE specify that "in the case of Circulars, the affected parties } \\
\text { should receive a hearing"; Art. } 24 \text { of the Law on Government (Law 50/1997) establishes that } \\
\text { public consultations with relevant sectors are expected in the elaboration or regulations such as } \\
\text { BE Circulars. }\end{array}$ \\
\hline & $\begin{array}{l}\text { The BE has used public consultations for proposed substantive technical changes in the } \\
\text { structure of financial regulations. On the BE website there is a section reserved for ESCB } \\
\text { consultations. These consultations are held through a public notification and give a certain } \\
\text { period (usually not less than three months) to make written comments. The comments received } \\
\text { are made public at the end of the consultation period. }\end{array}$ \\
\hline & $\begin{array}{l}\text { The documents Oversight Criteria for Low-value Payment Systems in Euro and The Objectives } \\
\text { of Electronic Money Systems Security are two examples of public consultations held in } 2002 \text { on } \\
\text { payment system oversight. In addition to formal consultation procedures, the BE maintains } \\
\text { continuous contact with the financial sector, organizations of service providers and payment } \\
\text { systems. Market participants have expressed appreciation with the authorities' efforts to involve } \\
\text { the affected parties in the regulatory process, even if the consultative period is sometimes } \\
\text { considered too short. }\end{array}$ \\
\hline & $\begin{array}{l}\text { All payment system decisions are discussed with the financial entities involved (about } \\
20 \text { member banks and the three associations) in a high level payment systems group, chaired by } \\
\text { the BE Director General. The group has met regularly twice a year for about three years. }\end{array}$ \\
\hline Assessment & Observed. \\
\hline \multicolumn{2}{|l|}{ Comments } \\
\hline \multicolumn{2}{|r|}{ VII. Public Availability of Information on Financial Policies } \\
\hline 7.1 & $\begin{array}{l}\text { Financial agencies should issue a periodic public report on the major developments of the } \\
\text { sector(s) of the financial system for which they carry designated responsibility. }\end{array}$ \\
\hline \multirow[t]{3}{*}{ Description } & $\begin{array}{l}\text { The BE Annual Report describes major developments in the financial sector, the Spanish } \\
\text { economy, and the international economy. Since } 2003 \text { it includes a Management Report. The } \\
2003 \text { Management Report includes a section on the payments systems operations as well as a } \\
\text { short description of the principal developments in the payment system during the year. }\end{array}$ \\
\hline & $\begin{array}{l}\text { Occasionally, the BE publishes reports on developments in the payment systems. The Bank of } \\
\text { Spain and Payment System Oversight includes extensive references to the current situation and } \\
\text { future reforms in the system. In addition, articles on the payment systems have been published } \\
\text { in the Financial Stability Review, e.g., "The Payment Systems Contribution to Financial } \\
\text { Stability: The Spanish Case" (No. 5, 2003), and "Evolution of Credit Cards as a Payment } \\
\text { Instrument in Spain (1996-2003)" (No. 5, 2005). }\end{array}$ \\
\hline & $\begin{array}{l}\text { The Annual Report and the Financial Stability Review (in Spanish only) are available at no cost } \\
\text { on the BE website. The website has a section on the payment system where statistical and other } \\
\text { information on the operations of the systems under oversight is regularly posted. }\end{array}$ \\
\hline Assessment & Partly observed. \\
\hline
\end{tabular}




\begin{tabular}{|c|c|}
\hline Comments & $\begin{array}{l}\text { The section on the payments systems in the Management Report should be developed further in } \\
\text { order to qualify for an observed rating. The planned yearly report on payment systems would } \\
\text { achieve this objective. }\end{array}$ \\
\hline 7.2 & $\begin{array}{l}\text { Financial agencies should seek to ensure that, consistent with confidentiality } \\
\text { requirements, there is public reporting of aggregate data related to their jurisdictional } \\
\text { responsibilities on a timely and regular basis. }\end{array}$ \\
\hline \multirow[t]{2}{*}{ Description } & $\begin{array}{l}\text { There is public reporting of aggregate data related to payment system operations on a timely } \\
\text { and regular basis. The information is presented in tables and graphs to make it easily accessible } \\
\text { and understandable to the public. The information is available in the payment system section of } \\
\text { the BE website, under the headings Blue Book Statistics, SLBE and SNCE. }\end{array}$ \\
\hline & $\begin{array}{l}\text { These reports contain yearly and monthly data and are updated every month, usually within a } \\
\text { month after the end of the reporting period. }\end{array}$ \\
\hline Assessment & Observed. \\
\hline \multicolumn{2}{|l|}{ Comments } \\
\hline 7.3 & $\begin{array}{l}\text { Where applicable, financial agencies should publicly disclose their balance sheets on a } \\
\text { preannounced schedule and, after a predetermined interval, publicly disclose information } \\
\text { on aggregate market transactions. }\end{array}$ \\
\hline \multirow[t]{5}{*}{ Description } & $\begin{array}{l}\text { Orientation } \mathrm{BCE} / 2002 / 10 \text { on the legal regime of accounting and elaboration of financial reports } \\
\text { in the ESCB is the basis for BE as well as for the other national central banks. It includes } \\
\text { fundamental accounting principles, defines assets and liabilities, rules for the composition of } \\
\text { the balance sheet, and valuation criteria. }\end{array}$ \\
\hline & $\begin{array}{l}\text { The economic regime of the BE is established in Art. } 4 \text { of LABE, including procedures for } \\
\text { elaboration, approval, and publicity of the balance sheet and annual accounts: }\end{array}$ \\
\hline & $\begin{array}{l}\text { "The government, upon proposal by the Economy and Finance Minister, shall have the } \\
\text { authority to approve the annual balance sheet and accounts of the Bank, which will be sent to } \\
\text { Parliament for informational purposes. Without prejudice to the terms of Article } 27 \text { of the } \\
\text { Statutes of the ESCB, the Bank shall be subject to external auditing by the National Audit } \\
\text { Tribunal, under the terms of Organic Law } 2 / 1982 \text {, of May } 12 \text {, on the National Audit Tribunal. } \\
\text { The report accompanying the annual balance sheet and accounts shall give further detail on } \\
\text { different operations or items on the balance sheet, according to their characteristics. In } \\
\text { particular, the Bank's contributions to the Deposit Guarantee Funds shall be detailed, as will any } \\
\text { loans or other operations transacted for the benefit of any other institution or person not on an } \\
\text { arm's-length basis, or which in any other way involve loss of profit or losses for the Bank. In } \\
\text { such cases the amount of such loss of profit or losses shall be specified." }\end{array}$ \\
\hline & $\begin{array}{l}\text { Articles } 7 \text { and } 29 \text { of RIBE further regulates the accounting system and the establishment and } \\
\text { publicity of the annual accounts and balance sheet of the BE. }\end{array}$ \\
\hline & $\begin{array}{l}\text { In addition, Art. } 29 \text { states that the annual accounts are developed by the Associate Directorate- } \\
\text { General for Internal Affairs; should be audited by internal and independent external auditors; } \\
\text { and should be published in the BOE as well as, in summary format, in the BE Statistical } \\
\text { Bulletin. Art. } 33 \text { also states that it should be sent to the National Audit Office within two } \\
\text { months of government approval. }\end{array}$ \\
\hline Assessment & Not applicable. \\
\hline Comments & $\begin{array}{l}\text { The DGO is part of the organizational structure of the BE and its funding and expenditures are } \\
\text { determined as part of BE's budget. }\end{array}$ \\
\hline 7.3 .1 & $\begin{array}{l}\text { Consistent with confidentiality and privacy of information on individual firms, aggregate } \\
\text { information on emergency financial support by financial agencies should be publicly disclosed } \\
\text { through an appropriate statement when such disclosure will not be disruptive to financial }\end{array}$ \\
\hline
\end{tabular}


stability.

\begin{tabular}{|c|c|}
\hline & lity. \\
\hline Description & \\
\hline Assessment & Not applicable. \\
\hline Comments & This is not a responsibility of the Payment System Department. \\
\hline 7.4 & Financial agencies should establish and maintain public information services. \\
\hline Description & $\begin{array}{l}\text { The Communications Department disseminates policy decisions and policy announcements, } \\
\text { provides information on the operating framework and objectives, publishes texts of major } \\
\text { speeches by senior officials, data, and research reports, arranges seminars, and maintains the } \\
\text { contact with the media. See website/pressroom. }\end{array}$ \\
\hline & $\begin{array}{l}\text { The BE uses various instruments in its communication policy. These can be grouped into two } \\
\text { categories: those addressing the media and those addressing the general public. }\end{array}$ \\
\hline & $\begin{array}{l}\text { In relation to the media, the BE issues information notes that are transmitted to more than a } \\
\text { hundred recipients by electronic mail. This notes are simultaneously posted on the BE website. } \\
\text { Some notes have a periodic character, e.g., monthly (balance sheets, mortgage market), } \\
\text { quarterly (international investments), or half-yearly (Financial Stability Report). In 2004, the } \\
\text { BE issued } 49 \text { information notes. }\end{array}$ \\
\hline & $\begin{array}{l}\text { The bank holds several events open to the press, linked to publications, conferences, economic } \\
\text { awards, etc. About a dozen such events were organized in } 2004 \text {. The BE regularly organizes } \\
\text { off-the-record meetings between high ranking BE officials and the specialized press, to brief } \\
\text { them on BE activities and the Spanish financial system in general. The BE also arranges } \\
\text { technical seminars for the press (the most recent being on the application of Basel II and the } \\
\text { new international accounting rules). }\end{array}$ \\
\hline & $\begin{array}{l}\text { The speeches of the governor ( } 22 \text { in } 2004) \text {, deputy governor ( } 2 \text { in } 2004 \text { ) and directors general } \\
\text { (e.g., Supervision } 1 \text {, Regulation } 10 \text {, Studies 5, respectively, in 2004) are posted on the website. } \\
\text { The governor's speeches are available on the English website; other speeches may be available } \\
\text { in English only on the Spanish website. }\end{array}$ \\
\hline & $\begin{array}{l}\text { The BE publishes information material in the form of books and pamphlets for the general } \\
\text { public. Recently, it published a Monetary Policy Glossary and is developing a Welcome } \\
\text { Manual to the BE providing information on its functions and internal organization. }\end{array}$ \\
\hline & $\begin{array}{l}\text { Addressing the same general public, the BE is developing a special section on the website in } \\
\text { which it offers all necessary practical information that a bank client needs in daily contacts with } \\
\text { financial entities. In addition, the BE website contains an email address, telephone, and fax } \\
\text { numbers to receive questions from the general public. The website includes a wide range of } \\
\text { information. The publications relating to banking supervision and regulation and financial } \\
\text { markets can be found in Spanish in the Banking Supervision section. However, the English } \\
\text { language website for banking supervision is not updated and does not include any publications. } \\
\text { General information on banking supervision in Spain can be found in the section About us/ } \\
\text { functions/ banking supervision, but not on the Banking Supervision section. }\end{array}$ \\
\hline & $\begin{array}{l}\text { A permanent information source regarding BE policies and the situation in the financial sector } \\
\text { is the BE Publications Service. See 7.4.1. }\end{array}$ \\
\hline Assessment & Observed. \\
\hline Comments & $\begin{array}{l}\text { The English- and Spanish-language websites should be better coordinated, e.g., with respect to } \\
\text { published speeches. The payment systems section should be updated to reflect the fact that the } \\
\text { SPI no longer exists. }\end{array}$ \\
\hline 7.4 .1 & $\begin{array}{l}\text { Financial agencies should have a publications program, including a periodic public report on } \\
\text { their principal activities issued at least annually. }\end{array}$ \\
\hline
\end{tabular}




\begin{tabular}{|c|c|}
\hline \multirow[t]{4}{*}{ Description } & $\begin{array}{l}\text { The publications program was established in the Resolution March 28, } 2000 \text { of the BE } \\
\text { governing board. }\end{array}$ \\
\hline & $\begin{array}{l}\text { The BE has a publications program with periodic reports including a monthly evaluation of the } \\
\text { general economic situation (Boletín Económico), an evaluation of national financial stability } \\
\text { (Estabilidad Financiera), official statistics (Boletín Estadístico, Cuentas Financieras de la } \\
\text { Economía Española, Balanza de Pagos, Central de Balances, Indicadores Económicos), bank } \\
\text { supervision activities (Memoria de la Supervisión Bancaria), public debt management } \\
\text { operations (Informe Anual del Mercado de Deuda, boletines diarios del mercado de deuda } \\
\text { pública) and complaints (Memoria del Servicio de Reclamaciones). }\end{array}$ \\
\hline & $\begin{array}{l}\text { In addition, the BE Annual Report, published in June, include a Management Report explaining } \\
\text { the main activities of the institution. This report is accompanied by the Speech of the Governor, } \\
\text { in which the economic and financial situation is evaluated, as well as the principal recent } \\
\text { changes in the activities of the bank. All these publications are distributed to the press and to } \\
\text { more than } 3,200 \text { subscribers, and posted on the website. }\end{array}$ \\
\hline & $\begin{array}{l}\text { The Management Report section of the BE's Annual Report only covers the operation of } \\
\text { payment systems, not the oversight activities. }\end{array}$ \\
\hline Assessment & Partly observed. \\
\hline Comments & $\begin{array}{l}\text { A periodic public report on payment system oversight is needed for an observed rating. The } \\
\text { planned yearly report on payment systems including oversight activities would achieve this } \\
\text { objective. Payment system oversight activities should be mentioned in the Management Report. }\end{array}$ \\
\hline 7.4 .2 & $\begin{array}{l}\text { Senior financial agency officials should be ready to explain their institution's objective(s) and } \\
\text { performance to the public, and have a presumption in favor of releasing the text of their } \\
\text { statements to the public. }\end{array}$ \\
\hline \multirow[t]{3}{*}{ Description } & $\begin{array}{l}\text { Article } 10 \text { of LABE states that " } 1 \text {. The Bank shall regularly inform Parliament and the } \\
\text { government of the objectives and the implementation of monetary policy (...). To this end, the } \\
\text { Governor of the Bank may be asked to appear, in accordance with Parliamentary regulations, } \\
\text { before any Congress or Senate committee or joint committee of both chambers, or be asked to } \\
\text { attend for this purpose cabinet meetings or meetings of its Commission for Economic Affairs. }\end{array}$ \\
\hline & $\begin{array}{l}\text { 2. In addition, the Governor of the Bank may be asked to attend the meetings of the Consejo de } \\
\text { Politica Fiscal y Financiera de las Comunidades Autónomas (...) and to report on issues within } \\
\text { the scope of the Bank's authority, with a view to facilitating the tasks of financial coordination } \\
\text { of the above-mentioned Consejo." }\end{array}$ \\
\hline & $\begin{array}{l}\text { In practice, the Governor appears regularly before parliament, usually three times a year. In } \\
\text { addition, its common that the Governor, Deputy Governor or Directors General make public } \\
\text { speeches. See 7.4. }\end{array}$ \\
\hline Assessment & Observed. \\
\hline Comments & $\begin{array}{l}\text { The English- and Spanish-language websites should be better coordinated, e.g., with respect to } \\
\text { published speeches. }\end{array}$ \\
\hline 7.5 & $\begin{array}{l}\text { Texts of regulations and any other generally applicable directives and guidelines issued by } \\
\text { financial agencies should be readily available to the public. }\end{array}$ \\
\hline \multirow[t]{2}{*}{ Description } & $\begin{array}{l}\text { The relevant rules and regulations are contained in a number of Circulars that the BE issues and } \\
\text { modifies as part of its functions (Arts. } 3.1 \text {. and } 16 \text { of LABE, Art. } 7 \text { of RIBE). New Circulars are } \\
\text { published in the BOE (Arts. } 3 \text { of LABE and } 8.9 \text { of RIBE). However, the system of Circulars is } \\
\text { hard to follow due to modifications. The legislation affecting the BE (as well as the financial } \\
\text { entities) is regularly updated on the BE website under "Legislation," e.g., the Circulars. }\end{array}$ \\
\hline & $\begin{array}{l}\text { In addition, the Payment System section of the website contains a section on Legislation which } \\
\text { includes links to key laws and regulations (national and European) on consumer protection. }\end{array}$ \\
\hline
\end{tabular}




\begin{tabular}{|c|c|}
\hline Assessment & Observed. \\
\hline Comments & $\begin{array}{l}\text { Due to the many modifications of BE circulars it is recommended that the overall organization } \\
\text { of BE circulars be updated in order to improve transparency. }\end{array}$ \\
\hline 7.6 & $\begin{array}{l}\text { Where there are deposit insurance guarantees, policyholder guarantees, and any other } \\
\text { client asset protection schemes, information on the nature and form of such protections, } \\
\text { the operating procedures, how the guarantee is financed, and the performance of the } \\
\text { arrangement should be publicly disclosed. }\end{array}$ \\
\hline \multirow[t]{2}{*}{ Description } & $\begin{array}{l}\text { RDL 4/1980, RDL } 18 / 1982 \text {, and RD } 2606 / 1996 \text { contain the legal regime for deposit insurance; } \\
\text { RD 948/2001 for investor protection. }\end{array}$ \\
\hline & $\begin{array}{l}\text { In the website of the Deposit Guarantee Fund (www.fgd.es) detailed information can be found } \\
\text { on the deposit guarantee. The BE also has a website section dedicated to deposit insurance. }\end{array}$ \\
\hline Assessment & Not applicable. \\
\hline Comments & This is not a responsibility of the Payment Systems Oversight. \\
\hline 7.7 & $\begin{array}{l}\text { Where financial agencies oversee consumer protection arrangements (such as dispute } \\
\text { settlement processes), information on such arrangements should be publicly disclosed. }\end{array}$ \\
\hline Description & $\begin{array}{l}\text { Article } 31 \text { Law } 44 / 2002 \text { and Art. } 8.4 \text { Order ECO/734/2004, gather the BE faculties to verify the } \\
\text { regulations for the departments and services to attend clients. Chapter II of BE Circular } 8 / 1990 \\
\text { defines the organization and functions of the BE Complaints Service and Art. } 5 \text { e) and } 48.2 \text { LDI } \\
\text { state sanction for lack of transparency in regard to the operations of credit entities. The credit } \\
\text { entities (EC) should have organs for the solution of the conflicts raised by the clients, and } \\
\text { should give information about this in their annual reports. }\end{array}$ \\
\hline Assessment & Not applicable. \\
\hline Comments & This is not the responsibility of the Payment Systems Department. \\
\hline \multicolumn{2}{|r|}{ 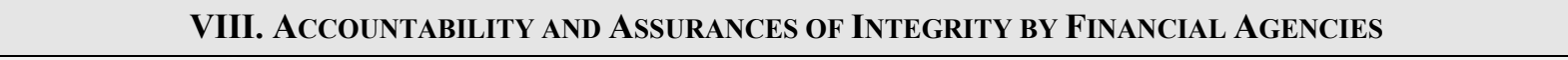 } \\
\hline 8.1 & $\begin{array}{l}\text { Officials of financial agencies should be available to appear before a designated public } \\
\text { authority to report on the conduct of financial policies, explain the policy objective(s) of } \\
\text { their institution, describe their performance in pursuing their objective(s), and, as } \\
\text { appropriate, exchange views on the state of the financial system. }\end{array}$ \\
\hline \multirow[t]{3}{*}{ Description } & $\begin{array}{l}\text { Article } 10 \text { of LABE states that " } 1 \text {. The Bank shall regularly inform Parliament and the } \\
\text { government of the objectives and the implementation of monetary policy (...). To this end, the } \\
\text { Governor of the Bank may be asked to appear, in accordance with Parliamentary regulations, } \\
\text { before any congress or senate committee or joint committee of both chambers, or be asked to } \\
\text { attend for this purpose cabinet meetings or meetings of its Commission for Economic Affairs. }\end{array}$ \\
\hline & $\begin{array}{l}\text { 2. In addition, the Governor of the Bank may be asked to attend the meetings of the Consejo de } \\
\text { Politica Fiscal y Financiera de las Comunidades Autónomas (...) and to report on issues within } \\
\text { the scope of the Bank's authority, with a view to facilitating the tasks of financial coordination } \\
\text { of the above-mentioned Consejo." }\end{array}$ \\
\hline & $\begin{array}{l}\text { In practice, the Governor appears regularly before parliament, usually three times a year. In } \\
2004 \text { the governor appeared before the Budget Commissions of Congress (Deputies, October } 13 \\
\text { and Senate, November 24), as well as before the Economy and Finance Commission (Deputies, } \\
\text { June 30) to discuss economic conditions and policy. The appearances are made public in the } \\
\text { Diario de Sesiones del Congreso. The BE, usually through the Governor or a Director General, } \\
\text { informs on the objectives and the performance of its functions. Public speeches by the } \\
\text { Governor, Deputy Governor, and Directors General are posted on the website and in some cases } \\
\text { included in other BE publications. }\end{array}$ \\
\hline
\end{tabular}




\begin{tabular}{|c|c|}
\hline Assessment & Observed. \\
\hline \multicolumn{2}{|l|}{ Comments } \\
\hline 8.2 & $\begin{array}{l}\text { Where applicable, financial agencies should publicly disclose audited financial statements } \\
\text { of their operations on a preannounced schedule. }\end{array}$ \\
\hline Description & $\begin{array}{l}\text { Articles } 4.2 \text { of LABE and } 29 \text { and } 32 \text { of RIBE establish the obligation to submit the BE } \\
\text { accounts, already audited by the Internal Audit Department, to the Audit Committee, external } \\
\text { auditors, and the National Audit Office. The Governing Council submits the annual accounts } \\
\text { for government approval, upon proposal by the Minister of the Economy. The annual accounts } \\
\text { of the BE, including notes to the accounts and the audit report, are included in the Annual } \\
\text { Report of the BE, issued in June. }\end{array}$ \\
\hline Assessment & Not applicable. \\
\hline Comments & $\begin{array}{l}\text { The DGO is part of the organizational structure of the BE; its funding and expenditures are } \\
\text { determined as part of the BE's budget. }\end{array}$ \\
\hline 8.2 .1 & $\begin{array}{l}\text { Financial statements, if any, should be audited by an independent auditor. Information on } \\
\text { accounting policies and any qualification to the statements should be an integral part of the } \\
\text { publicly disclosed financial statements. }\end{array}$ \\
\hline \multirow[t]{2}{*}{ Description } & $\begin{array}{l}\text { Article } 29 \text { and following of RIBE and } 4.2 \text { of LABE state that the BE is subject to independent } \\
\text { external auditing pursuant to Art. } 27 \text { of the Statutes of the ESCB. }\end{array}$ \\
\hline & $\begin{array}{l}\text { The external auditors report (see, for instance, the } 2003 \text { Annual Report of the BE, page 226) } \\
\text { contains information on accounting policies and qualifications to the statements. The annual } \\
\text { accounts include balance sheet, income statement, notes to the accounts, and the statement of } \\
\text { the independent auditor. Contributions to the Deposit insurance fund and all operations not at } \\
\text { market value are detailed separately in the report (see 7.3.1). }\end{array}$ \\
\hline Assessment & Not applicable. \\
\hline Comments & $\begin{array}{l}\text { The DGO is part of the organizational structure of the BE; its funding and expenditures are } \\
\text { determined as part of the BE's budget. }\end{array}$ \\
\hline 8.2 .2 & $\begin{array}{l}\text { Internal governance procedures necessary to ensure the integrity of operations, including } \\
\text { internal audit arrangements, should be publicly disclosed. }\end{array}$ \\
\hline \multirow[t]{2}{*}{ Description } & $\begin{array}{l}\text { DA } 2^{\mathrm{a}} \text { of the Financial Law established a series of measures to improve the efficiency and } \\
\text { quality of supervision, including issuance of an Annual Report on Supervision that should } \\
\text { contain an internal audit of the functioning of BE's governing bodies, with a focus on their } \\
\text { decisions and the suitability of the normative procedures applied. }\end{array}$ \\
\hline & $\begin{array}{l}\text { Articles } 29 \text { and } 32 \text { of RIBE regulate the Internal Audit Department, and Arts. } 79-88 \text { its internal } \\
\text { control functions. The By-laws of the Internal Audit Department, approved by BE's Executive } \\
\text { Commission on } 28 \text { November 2001, are made public on the website/About us/Functional } \\
\text { Structure/Internal Audit Department. The activities of the internal audit are also disclosed in the } \\
\text { Management Report Section of the Annual Report, under the heading "Internal Organization } \\
\text { and Administration." }\end{array}$ \\
\hline Assessment & Observed. \\
\hline \multicolumn{2}{|l|}{ Comments } \\
\hline 8.3 & $\begin{array}{l}\text { Where applicable, information on the operating expenses and revenues of financial } \\
\text { agencies should be publicly disclosed annually. }\end{array}$ \\
\hline Description & $\begin{array}{l}\text { Articles } 4 \text { of LABE and } 28 \text { of RIBE specify that the budget, once approved by the Governing } \\
\text { Council, shall be forwarded to the government, which will submit it to Parliament for approval. }\end{array}$ \\
\hline
\end{tabular}




\begin{tabular}{|c|c|}
\hline & $\begin{array}{l}\text { "The budget shall be prospective in nature, and shall not be consolidated with other State public } \\
\text { sector budgets. The government, upon proposal by the Economy and Finance Minister, shall } \\
\text { have the authority to approve the annual balance sheet and accounts of the Bank, which will be } \\
\text { sent to Parliament for informational purposes (...). The report accompanying the annual } \\
\text { balance sheet and accounts shall give further detail on different operations or items on the } \\
\text { balance sheet, according to their characteristics (...) or which in any other way involve loss of } \\
\text { profit or losses for the Bank. In such cases the amount of such loss of profit or losses shall be } \\
\text { specified." See notes of the loss and profit account on page } 118 \text { of the Annual Report } 2003 \text {. }\end{array}$ \\
\hline Assessment & Not applicable. \\
\hline Comments & $\begin{array}{l}\text { The DGO is part of the organizational structure of the BE; its funding and expenditures are } \\
\text { determined as part of the BE's budget. }\end{array}$ \\
\hline 8.4 & $\begin{array}{l}\text { Standards for the conduct of personal financial affairs of officials and staff of financial } \\
\text { agencies and rules to prevent exploitation of conflicts of interest, including any general } \\
\text { fiduciary obligation, should be publicly disclosed. }\end{array}$ \\
\hline Description & 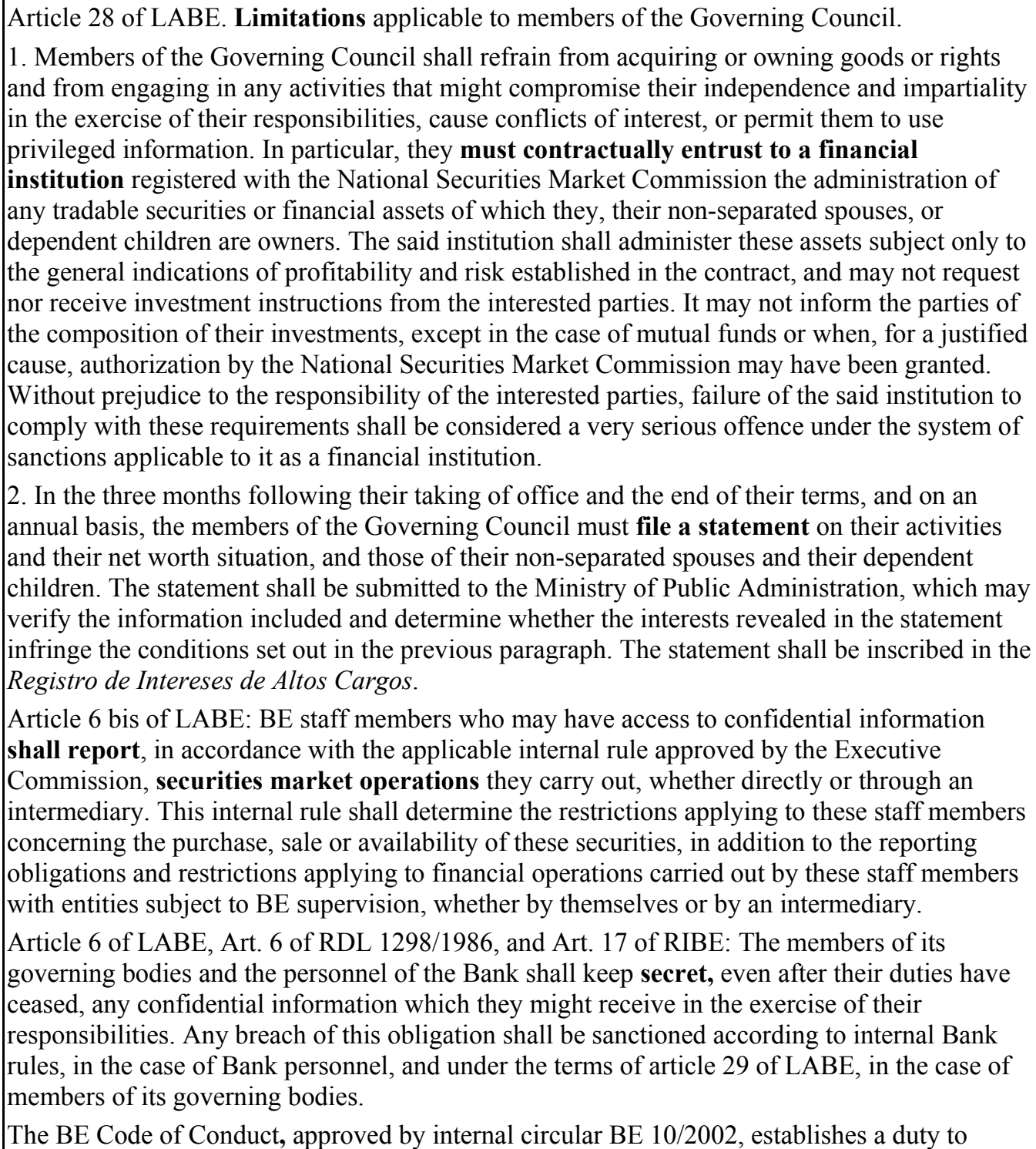 \\
\hline
\end{tabular}




\begin{tabular}{|l|l|}
\hline & $\begin{array}{l}\text { annually register financial activities of all staff and their families. The Code of conduct is not } \\
\text { publicly available, but is posted on the internal website. }\end{array}$ \\
\hline Assessment & Broadly observed. \\
\hline Comments & Public disclosure of the Code of Conduct would be desirable. \\
\hline 8.4 .1 & $\begin{array}{l}\text { Information about legal protections for officials and staff of financial agencies in the conduct of } \\
\text { their official duties should be publicly disclosed. }\end{array}$ \\
\hline Description & $\begin{array}{l}\text { The RIBE establishes rules in this respect in Art. 25 (Protection for BE staff in the conduct of } \\
\text { their official duties) and Art. 26 (Legal defense). This has support in Title X of Law 30/1992 } \\
\text { (Régimen Jurídico de las Administraciones Públicas y del Procedimiento Administrativo } \\
\text { Común) and in the Royal Decree 429/1993. The legislation as well as RIBE are posted on the } \\
\text { website. }\end{array}$ \\
\hline Assessment & Observed. \\
\hline Comments & \multicolumn{2}{|c|}{} \\
\hline
\end{tabular}

Table 11. Summary Observance of IMF's MFP Transparency Code_Payment System Oversight

\begin{tabular}{|l|l|l|}
\hline \multirow{2}{*}{\multicolumn{1}{c|}{$\begin{array}{c}\text { Assessment } \\
\text { Grade }\end{array}$}} & \multicolumn{2}{c|}{ Practices Grouped by Assessment Grade } \\
\cline { 2 - 3 } & \multicolumn{1}{|c|}{ Count } & \multicolumn{1}{c|}{ List } \\
\hline Observed & 21 & $\begin{array}{l}5.1 ; 5.1 .1 ; 5.1 .2 ; 5.1 .3 ; 5.1 .4 ; 5.2 ; 5.3 ; 5.3 .1 ; 5.4 ; 5.5 ; 6.1 ; 6.1 .1 ; 6.2 ; 6.4 ; 7.2 ; \\
7.4 ; 7.4 .2 ; 7.5 ; 8.1 ; 8.2 .2 ; 8.4 .1\end{array}$ \\
\hline Broadly observed & 2 & $6.1 .5 ; 8.4$ \\
\hline Partly observed & 3 & $6.3 ; 7.1 ; 7.4 .1$ \\
\hline Non-observed & & \\
\hline Not applicable & 10 & $6.1 .2 ; 6.1 .3 ; 6.1 .4 ; 7.3 ; 7.3 .1 ; 7.6 ; 7.7 ; 8.2 ; 8.2 .1 ; 8.3$ \\
\hline
\end{tabular}

\section{Recommended Action Plan and Authorities' Response to the Assessment}

\section{Recommended action plan}

40. Overall, the DGO already adheres to almost all of the practices of the Transparency Code. To further refine transparency, the IMF mission welcomes BE plans to gather what are currently high quality occasional publications and articles in a periodic separate report on payment systems. Payment system oversight activities (in addition to payment system operations) should also be mentioned in the Management Report section of BE's Annual Report.

41. In addition, the Bank of Spain may want to consider making public the content of MoUs with other national agencies, in addition to their existence (the year they were signed). Knowledge of consultation procedures between domestic agencies provides the public with assurances that financial agencies have established mechanisms to deal with issues that cut across their mandates. 
42. To further enhance transparency, the payment systems section of BE's website should be updated with regard to the SPI. Due to the many modifications of BE circulars it would also be desirable that the organization of BE circulars be updated so as to improve transparency of the regulation in force.

\section{Table 12. Recommended Action Plan to Improve Observance of IMF's MFP Transparency Code Practices-Payment Systems Oversight}

\begin{tabular}{|c|c|}
\hline Reference Practice & Recommended Action \\
\hline \multicolumn{2}{|c|}{\begin{tabular}{l|l} 
VI. Open Process for & \\
Formulating and Reporting of & \\
Financial Policies & \\
\end{tabular}} \\
\hline $\begin{array}{l}\text { 6.1.5 Where applicable, formal } \\
\text { procedures for information sharing } \\
\text { and consultation between financial } \\
\text { agencies (including central banks), } \\
\text { domestic and international, should } \\
\text { be publicly disclosed. }\end{array}$ & $\begin{array}{l}\text { Make public the content of the MoUs, not only the year they were signed. } \\
\text { Knowledge of consultation procedures between domestic and/or } \\
\text { international agencies provides the public with assurances that financial } \\
\text { agencies have established mechanisms to deal with issues that cut across } \\
\text { their mandates. }\end{array}$ \\
\hline $\begin{array}{l}6.3 \text { Financial agencies should issue } \\
\text { periodic public reports on how } \\
\text { their overall policy objectives are } \\
\text { being pursued. }\end{array}$ & $\begin{array}{l}\text { Issue a periodic report on payment systems, including how oversight } \\
\text { objectives are being pursued. }\end{array}$ \\
\hline $\begin{array}{l}\text { VII. Public Availability of } \\
\text { Information on Financial Policies }\end{array}$ & \\
\hline
\end{tabular}

7.1 Financial agencies should issue Issue a periodic report on payment systems, including major developments. a periodic public report on the major developments of the sector(s) of the financial system for which they carry designated responsibility.

7.4.1 Financial agencies should have a publications program, including a periodic public report on their principal activities issued at least annually.

VIII. Accountability and Assurance of Integrity by Financial Agencies

8.4 Standards for the conduct of personal financial affairs of officials and staff of financial agencies and rules to prevent exploitation of conflicts of interest, including any general fiduciary obligation, should be publicly disclosed.
Issue a periodic report on payment systems operations and oversight. Payment system oversight activities should also be mentioned in BE's Management Report.

Public disclosure of the internal Code of Conduct would strengthen confidence in the care with which the BE performs its multiple functions. 


\section{Authorities' response to the assessment}

43. The authorities are in broad agreement with the assessment. Appropriate measures are being implemented to tackle the recommended action plan. 